
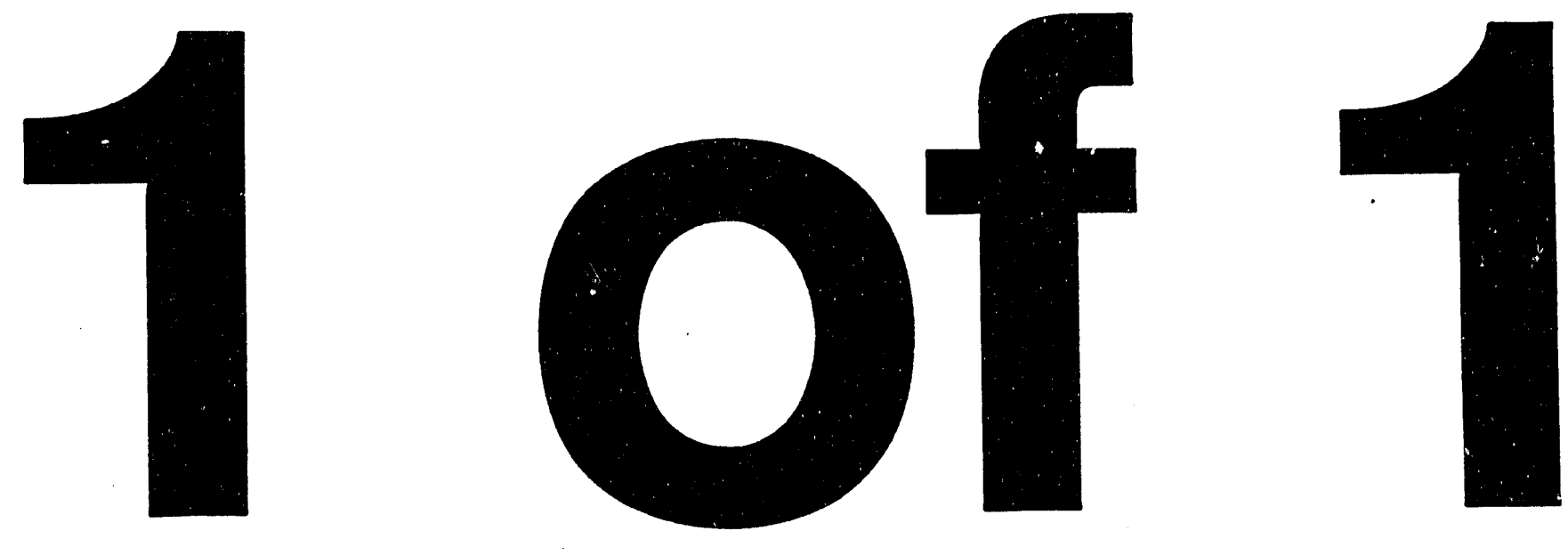


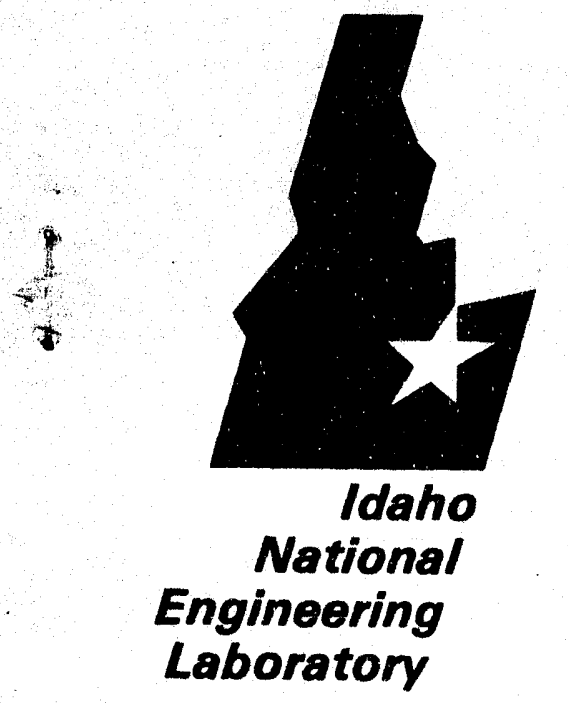

\author{
Managed \\ by the U.S. \\ Department \\ of Energy
}

EGG-MS-11416

August 1994

\section{Depleted Uranium Management Alternatives}

T. J. Hertzler

D. D. Nishimoto

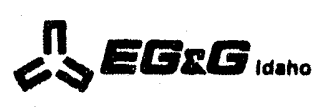

Work performed under DOE Contract No. DE-ACO7-761DC1570 
This document contains new concepts or the author(s) interpretation of new calculations and/or measurements; accordingly, EG\&G Idaho, Inc. is required by the United States Government to include the following disclaimer:

\section{DISCLAIMER}

This report was prepared as an account of work sponsored by an agency of the United States Government. Neither the United States Government nor any agency thereof, nor any of their employees, makes any warranty, express of implied, or assumes any legal liability or responsibility for the accuracy, completeness, or usefuiness of any intormation, apparatus, product or process disclosed, or represents that its use would not infringe privately owned rights. References herein to any specific commercial product. process, or service by trade name, trademark, manufacturer, or othenwise, does not necessarily constitute or imply its endorsement, recommendation, or favoring by the United States Government or any agency thereot. The views and opinions of authors expressed herein do not necessarily state or reflect those of the United States Government or any agency thereot. 


\section{Depleted Uranium Management Alternatives}

T. J. Hertzler

D. D. Nishimoto

Published August 1994

Waste Management Technology Division Science Applications International Corporation

545 Shoup Ave.

Idaho Falls, Idaho 83405-0697

Prepared for EG\&G Idaho, Inc. and the U.S. Department of Energy

Office of Environmental Restoration and Waste Management

Under DOE Idaho Operations Office

Contract DE-AC07-76ID01570 
Depleted Uranium Management Alternatives

EGG-MS-11416

Prepared by:

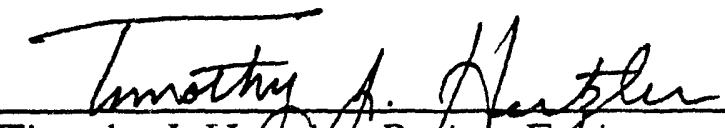

Timothy J. Hectzlet, Project Engineer

Science Applications International Corporation

Aneles A Mishimoto

Doughs D. Nishimoto, Senior Project Engineer

Science Applications International Corporation

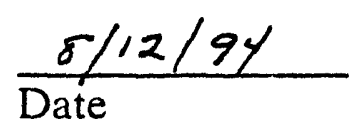

$\frac{8 / 8 / 94}{\text { Date }}$

Reviewed by:

will M. Law

Milo M. Larsen, Division Manager

Science Applications International Corporation

Reviewed and Approved by:
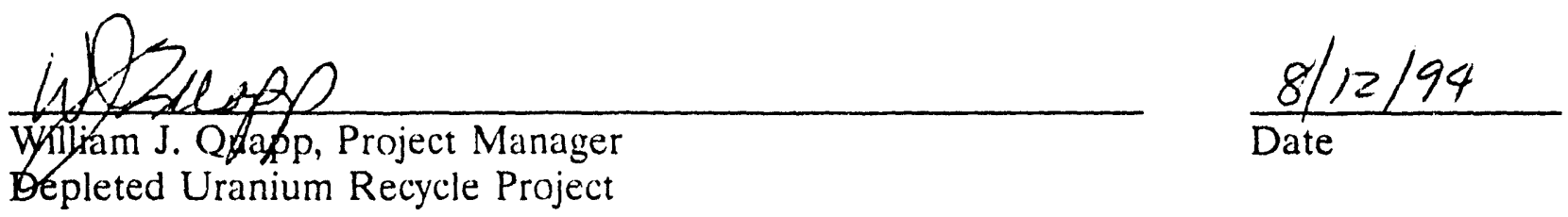


\begin{abstract}
This report evaluates two management alternatives for Department of Energy depleted uranium: continued storage as uranium hexafluoride, and conversion to uranium metal and fabrication to shielding for spent nuclear fuel containers. The results will be used to compare the costs with other alternatives, such as disposal. Cost estimates for the continued storage alternative are based on a life-cycle of 27 years through the year 2020. Cost estimates for the recycle alternative are based on existing conversion process costs and capital costs for fabricating the containers. Additionally, the recycle alternative accounts for costs associated with intermediate product resale and secondary waste disposal for materials generated during the conversion process.
\end{abstract}




\section{EXECUTIVE SUMMARY}

The Department of Energy (DOE) Office of Environmental Restoration and Waste Management has chartered a study to evaluate alternative management strategies for depleted uranium (DU) currently stored throughout the DOE complex. Historically, DU has been maintained as a strategic resource because of uses for depleted uranium metal and potential uses for further enrichment or for uranium oxide as breeder reactor blanket fuel. This report focuses on evaluating two management alternatives for DOE's DU: (a) the continued storage of DU as uranium hexafluoride $\left(\mathrm{UF}_{6}\right)$ and $(\mathrm{b})$ the conversion of $\mathrm{UF}_{6}$ to uranium metal and fabrication into shielding for spent nuclear fuel (SNF) or high-level radioactive waste (HLW) containers. DU disposal options are evaluated in a separate report, Depleted Uranium Disposal Options Evaluation.

Naturally occurring uranium consists primarily as the stable isotope ${ }^{238} \mathrm{U}$, with only about $0.7 \%$ being the fissile isotope ${ }^{235} \mathrm{U}$. The U.S. Government has been enriching uranium since the 1940 s, initially for military needs and then as fuel for commercial nuclear power plants. The enrichment process involves separating a feed stream of natural uranium hexafluoride $\left(\mathrm{UF}_{6}\right)$ into ${ }^{2}{ }^{235} \mathrm{U}$ enriched product stream and a much larger by-product stream depleted in ${ }^{235} \mathrm{U}$. Virtually all of the DU tails from the enrichment plants have been saved as a future resource in the form of solid $\mathrm{UF}_{6}$. DOE currently has a DU inventory of about 408,000 metric tons of uranium (MTU), the majority of which is located at the three gaseous diffusion plants in Paducah, Kentucky; Piketon, Ohio (i.e., the Portsmouth Gas Diffusion Plant); and Oak Ridge, Tennessee. As of March 1993, the gaseous diffusion plants were storing $375,000 \mathrm{MTU}$ as $\mathrm{UF}_{6}$ (corresponding to approximately 555,000 metric tons of $\mathrm{UF}_{6}$ ), accounting for about $92 \%$ of DOE's DU inventory.

The objective of this report is to provide preliminary data on two DU management alternatives (i.e., continued storage and use as shielding material in spent fuel casks), which DOE may use to compare with the costs of other alternatives, such as disposal. Cost estimates for the continued storage alternative are based upon a life-cycle of 27 years through the year 2020 . The cost estimates for the DU recycle alternative are based on existing conversion process costs for converting the $\mathrm{UF}_{6}$ to $\mathrm{U}$ metal and the capital costs for fabricating spent nuclear fuel containers. Additionally, costs associated with intermediate product resale (i.e., anhydrous hydrogen fluoride gas) and secondary waste disposal (i.e., magnesium fluoride) generated during the $\mathrm{UF}_{6}$ to $\mathrm{U}$ metal conversion process are accounted for in the recycle alternative.

The conclusions drawn from this study are as follows:

- Continued storage of the $\mathrm{UF}_{6}$ cylinders through the year 2020 is estimated to range from a low of $\$ 83$ million to a high of $\$ 129$ million based on current practices and necessary or planned new facility construction and increased maintenance and inspection activities.

- The feasibility of a large-scale DU recycle alternative and the cost associated with this alternative depend significantly on the system-wide acceptance of a spent fuel cask fabricated primarily out of DU metal. Acceptance by nuclear utilities, LOE Office of 
Civilian Radioactive Waste Management, and DOE Environmental Restoration and Waste Management must be unanimous for a large-scale DU recycle program to be implemented.

- The use of DU metal as a nonstructural shielding component in a SNF container is technically feasible. DU metal has been used in the past for gamma shielding in transportation casks and is acceptable to the U.S. Nuclear Regulatory Commission. The DU package conceptualized here is assumed to be licensable; however, additional design detail and analyses are required to verify its licensability prospects.

- A large, robust [21 pressurized water reactor (PWR)] SNF container using $45,975 \mathrm{~kg}$ of DU within the cask can be constructed to meet functional performance specifications for at-reactor storage and transportation handling, radiation shielding, decay heat dissipation, and structural integrity. Approximately 9,500 of these casks would be required to contain the 86,050 MTU of SNF requiring ultimate disposal in a HLW repository.

- The cost of fabricating the DU containers as conceptualized here [i.e., $\$ 1,469,270$ and $\$ 1,535,270$ for PWR and boiling water reactor (BWR) containers respectively], is not economically justifiable unless emplacement in the repository is acceptable and the cost of future DU disposal is avoided.

- The total cost for conversion and fabrication of the 9,500 containers is $\$ 14.2$ billion [ $\$ 165 / \mathrm{kgU}$ spent fuel contained $(\mathrm{SFC})$ ] without DU disposal credit, $\$ 8.8$ billion $(\$ 102.00 / \mathrm{kgU} \mathrm{SFC})$, and $\$ 3.5$ billion $(\$ 41.00 / \mathrm{kgU}$ SFC) with low-level radioactive waste (LLW) and Resource Conservation and Recovery Act (RCRA) disposal credits, respectively.

- The cost credit associated with the alternative of disposing of the DU reserves in a LI 'V or RCRA waste disposal facility, should disposal become necessary in the future, sigrıficantly reduces the cost of conversion and fabrication of a SNF container.

- Container costs with LLW disposal credit taken (i.e., $\$ 906,000$ and $\$ 972,000$ for PWR and BWR containers) are comparable to cost estimates reported by others for commercial metal transportation, storage, or dual-purpose casks.

- The cost estimates presented in this report do not parallel the total systern life-cycle cost for the entire SNF management program as developed by the Office of Civilian Radioactive Waste Management and its subcontractors. However, these estimates provide preliminary input data for a life-cycle analysis. 


\section{CONTENTS}

ABSTRACT $\ldots \ldots \ldots \ldots \ldots \ldots \ldots \ldots \ldots \ldots \ldots \ldots \ldots$ ii

EXECUTIVE SUMMARY $\ldots \ldots \ldots \ldots \ldots \ldots \ldots \ldots \ldots \ldots \ldots \ldots$

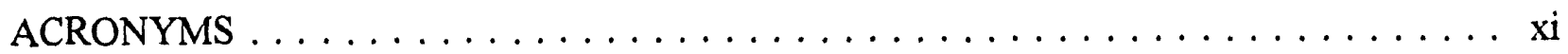

1. INTRODUCTION $\ldots \ldots \ldots \ldots \ldots \ldots \ldots \ldots \ldots \ldots \ldots \ldots \ldots \ldots$

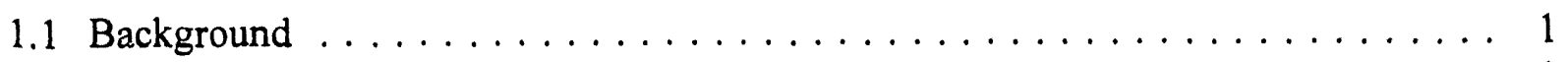

1.2 Objective and Approach $\ldots \ldots \ldots \ldots \ldots \ldots \ldots \ldots \ldots \ldots \ldots \ldots$

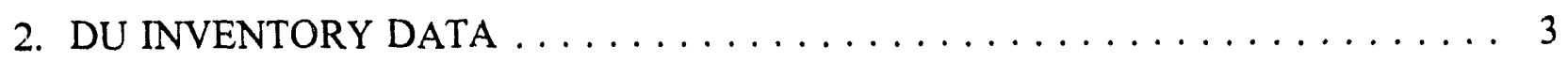

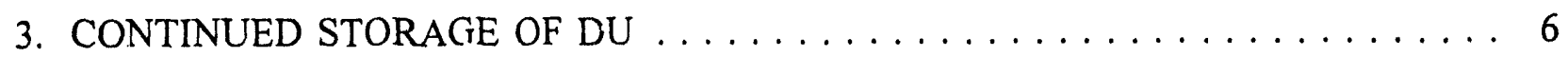

3.1 Regulatory Status/History of DU Storage $\ldots \ldots \ldots \ldots \ldots \ldots \ldots \ldots \ldots$

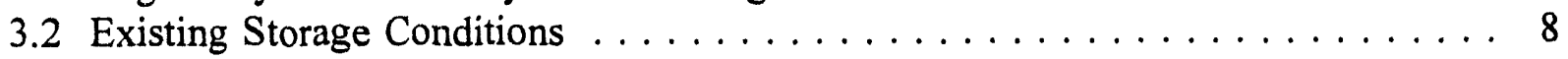

3.3 General Storage Cost Assumptions $\ldots \ldots \ldots \ldots \ldots \ldots \ldots \ldots \ldots \ldots \ldots$

3.4 Cost Estimates for Continued Cylinder Storage Until 2020 . . . . . . . . . . 13

4. DU SHIELDED SPENT NUCLEAR FUEL CONTAINER $\ldots \ldots \ldots \ldots \ldots \ldots$

4.1 Background . . . . . . . . . . . . . . . . . . . . 14

4.2 Quantities and Characteristics of Spent Nuclear Fuel $\ldots \ldots \ldots \ldots \ldots \ldots$

4.2.1 Quantities and Description ................. 15

4.3 Spent Nuclear Fuel Storage and Transportation Regulations . . . . . . . . . . 16

4.4 Conversion of $\mathrm{UF}_{6}$ to Uranium Metal $\ldots \ldots \ldots \ldots \ldots$

4.4 .1 Process Description . . . . . . . . . . . . . . . . . 18

4.4 .2 Process Mass Balance . . . . . . . . . . . . . . . . . 19

4.4 .3 Secondary Waste $\ldots \ldots \ldots \ldots \ldots \ldots \ldots \ldots$

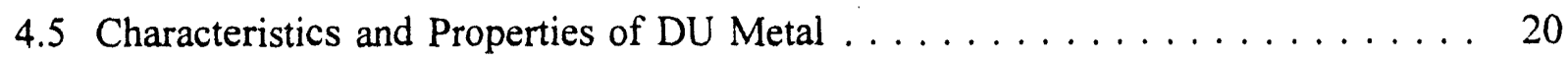

4.5.1 Radiation Shielding Properties .................. 20

4.5 .2 Mechanical and Thermal Properties ................ 22

4.6 Preliminary DU Shielded Package Concept $\ldots \ldots \ldots \ldots \ldots \ldots$

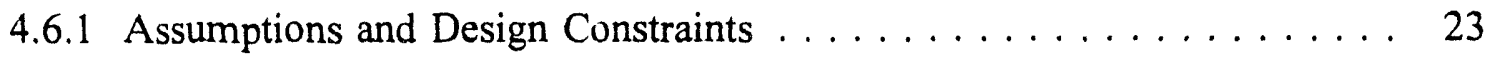

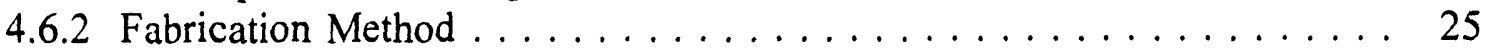

4.6 .3 DU Package Designs . . . . . . . . . . . . . . . . . 28 
4.6.4 Mass and Weight of Package Components . . . . . . . . . . . . . . . . 29

4.6 .5 Quantity of Spent Fuel Packages Required . . . . . . . . . . . . . . . 32

4.7 DU SNF Package Preliminary Analyses $\ldots \ldots \ldots \ldots \ldots \ldots \ldots$

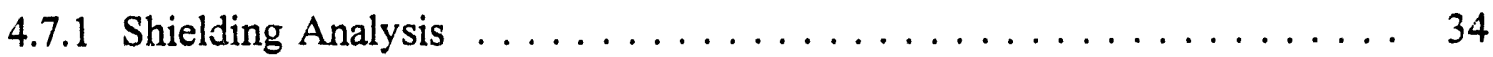

4.7 .2 Structural Analysis . . . . . . . . . . . . . . . . 35

4.8 DU SNF Package Cost Estimates $\ldots \ldots \ldots \ldots \ldots \ldots \ldots \ldots \ldots \ldots$

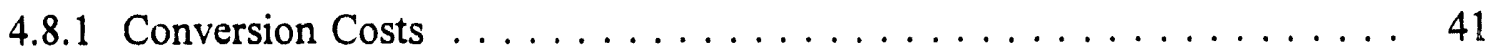

4.8 .2 Container Capital Costs . . . . . . . . . . . . . . . . . 43

4.8 .3 Total Container Cost Summary . . . . . . . . . . . . . . 46

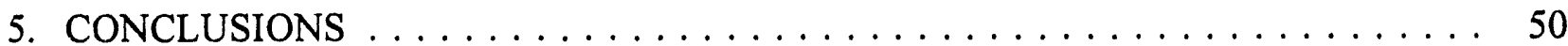

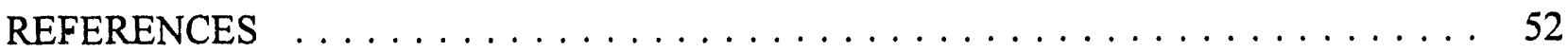

Appendix A-Design Basis Fuel Radioactive Source Term . . . . . . . . . . A2

Appendix B-Spent Nuclear Fuel Storage and Transport Regulations . . . . . . . . . . B2 


\section{FIGURES}

Figure 1. Conventional Batch Process for Uranium Metal Production $\ldots \ldots \ldots \ldots$

Figure 2. Cast Interlocking Ring Construction $\ldots \ldots \ldots \ldots$

Figure 3. Cast or Wrought Segmented Construction $\ldots \ldots \ldots \ldots \ldots \ldots$

Figure 4. Longitudinal Cross-Section $\ldots \ldots \ldots \ldots \ldots \ldots \ldots$

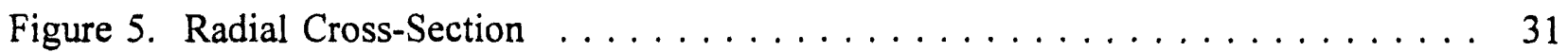

Figure 6. Relative Thickness of Stainless Steel and DU at Surface Dose Rate . . . . . 36

Figure 7. Relative Thickness of Stainless Steel and DU, at 2-m Dose Rate . . . . . 37

Figure 8. Relative Thickness of Polyethylene $\ldots \ldots \ldots \ldots \ldots$

Figure 9. Container Orientation During Tip-Over $\ldots \ldots \ldots \ldots \ldots$

Figure 10. Free Body Diagram Showing Resultant Force and Moment . . . . . . . 42 


\section{TABLES}

Table 1. Government-Owned Uranium Inventories as of $3 / 31 / 93$ (MTU) $\ldots \ldots \ldots \ldots \ldots$

Table 2. DOE Depleted Uranium Inventory as of $6 / 30 / 92^{\mathrm{a}} \ldots \ldots \ldots \ldots \ldots \ldots$

Table 3. DU Storage Cylinders as of $12 / 1 / 92 \ldots \ldots \ldots \ldots \ldots \ldots \ldots \ldots \ldots$

Table 4. Cost Estimate for Continued Storage of $\mathrm{UF}_{6}$ Cylinders $\ldots \ldots \ldots \ldots \ldots$

Table 5. Design-Basis Fuel Parameters $\ldots \ldots \ldots \ldots \ldots \ldots \ldots \ldots \ldots \ldots \ldots$

Table 6. Depleted Uranium Stoichiometric Mass Balance . . . . . . . . . . . . . . . 19

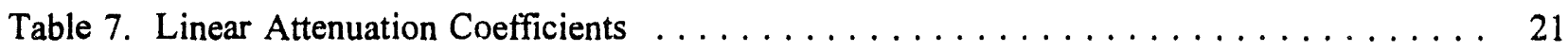

Table 8. Thickness of Uranium Shield Equivalent to $10 \mathrm{~cm}$ of Lead $\ldots \ldots \ldots \ldots \ldots$

Table 9. Material Properties $\ldots \ldots \ldots \ldots \ldots \ldots \ldots \ldots \ldots \ldots \ldots \ldots \ldots \ldots \ldots$

Table 10. Weights of the Major Components $\ldots \ldots \ldots \ldots \ldots \ldots \ldots$

Table 11. Total Estimated Operational Weights . . . . . . . . . . . . . . . . 29

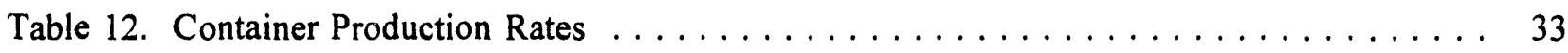

Table 13. Containment Structure All-wable Stress Limits $\ldots \ldots \ldots \ldots \ldots$

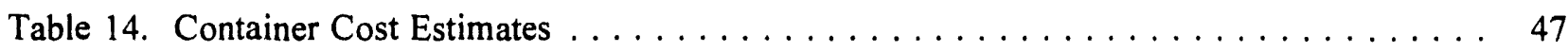

Table 15. Total Container Cost Summary $\ldots \ldots \ldots \ldots \ldots \ldots \ldots \ldots \ldots \ldots$

Table 16. DU Disposal Credits $\ldots \ldots \ldots \ldots \ldots \ldots \ldots \ldots \ldots \ldots \ldots \ldots$ 


\section{ACRONYMS}

AEA

ASME

ASTM

$B \& W$

BWR

CFR

CRWMS

DOE

DOT

DU

EPA

GA

GDP

GE

$\mathrm{HF}$

HLW

ISFSI

LCC

LLW

LWR

$\mathrm{M} \& \mathrm{O}$

MGD

MMES

MPC

MPU

MRS

MTIHM

MTU

NNO

NRC
Atomic Energy Act

American Society of Mechanical Engineers

American Society for Testing and Materials

Babcock and Wilcox Company

boiling water reactor

Code of Federal Regulations

Civilian Radioactive Waste Management System

Department of Energy

Department of Transportation

depleted uranium

Environmental Protection Act

General Atomic

gaseous diffusion plant

General Electric

hydrogen fluoride

high-level waste

Independent Spent Fuel Storage Installation

life-cycle cost

low-level waste

light water reactor

management and operations

mined geologic disposal

Martin Marietta Energy Systems, Inc.

multi-purpose canister

multi-purpose unit

monitored retrievable storage

metric tons of initial heavy metal

metric tons of uranium

no new orders

Nuclear Regulatory Commission 
NTS

NWPA

OAC

OCRWM

OEPA

PWR

RCRA

SAR

SFC

SNF

UEA

USEPA
Nevada Test Site

Nuclear Waste Policy Act

Ohio Administrative Code

Office of Civilian Radioactive Waste Management

Ohio Environmental Protection Agency

pressurized water reactor

Resource Conservation and Recovery Act

safety analysis report

spent fuel contained

spent nuclear fuel

uranium-enriched activity

United States Environmental Protection Agency 


\section{DEPLETED URANIUM MANAGEMENT ALTERNATIVES}

\section{INTRODUCTION}

The Department of Energy (DOE) Office of Environmental Restoration and Waste Management has chartered a study to evaluate alternative management strategies for depleted uranium (DU) currently stored throughout the DOE complex. Historically, DU has been maintained as a strategic resource because of uses for depleted uranium metal and potential uses for further enrichment or for uranium oxide as breeder reactor blanket fuel. This report focuses on evaluating two management alternatives for DOE's DU: (a) the continued storage of DU as uranium hexafluoride $\left(\mathrm{UF}_{6}\right)$ and $(b)$ the conversion of $\mathrm{UF}_{6}$ to uranium metal and fabrication into shielding for spent nuclear fuel (SNF) or high-level radioactive waste (HLW) containers. DU disposal options are evaluated in a separate report, Depleted Uranium Disposal Options Evaluation. ${ }^{1}$

\subsection{Background}

Naturally occurring uranium consists primarily as the stable isotope ${ }^{238} \mathrm{U}$, with only about $0.7 \%$ being the fissile isotope ${ }^{235} \mathrm{U}$. The U.S. Government has been enriching uranium since the 1940s, initially for military needs. During the 1960s and 1970s, primary use of the enriched product was shifted from military applications to providing fuel for commercial nuclear power plants. The Oak Ridge Gaseous Diffusion Plant (GDP) was the first operational uranium enrichment facility, followed by the Portsmouth and Paducah GDPs, which were built in the 1950s. The enrichment process involves separating a feed stream of natural uranium hexafluoride $\left(\mathrm{UF}_{6}\right)$ into a ${ }^{235} \mathrm{U}$-enriched product stream and a much larger by-product stream depleted in ${ }^{235} \mathrm{U}$. Generally, 5 to $10 \mathrm{~kg}$ of DU are produced for every kilogram of enriched uranium for commercial applications, while up to $200 \mathrm{~kg}$ of DU are produced for each kilogram of highly enriched uranium. ${ }^{2}$ Virtually all of the depleted uranium tails from the enrichment plants have been saved as a future resource in the form of solid $U_{6}$.

DOE currently has a DU inventory of about 408,000 metric tons of uranium (MTU). The majority of DOE's DU is in the form of uranium hexafluoride at the three gaseous diffusion plants in Paducah, Kentucky; Piketon, Ohio (i.e., the Portsmouth GDP); and Oak Ridge, Tennessee. (Note: The K-25 Gaseous Diffusion Plant in Oak Ridge has been shut down since 1985.) As of March 1993, the gaseous diffusion plants were storing 375,000 MTU as $\mathrm{UF}_{6}$ (corresponding to approximately 555,000 metric tons of $\mathrm{UF}_{6}$ ), accounting for about $92 \%$ of DOE's DU inventory and $80 \%$ of the total uranium inventory within the DOE complex. ${ }^{3}$ Because of the limited near-term demand for DU and the large quantities of DU presently available, DOE is evaluating various DU management strategies.

\subsection{Objective and Approach}

The objective of this report is to provide preliminary data on two DU management alternatives (i.e., continued storage and use as shielding), which DOE may use to compare with the costs of other alternatives, such as disposal. Cost estimates for the continued storage 
alternative are based on 27 years through the year 2020. The cost estimates for the DU recycle alternative are based on the cost of converting the $\mathrm{UF}_{6}$ to $\mathrm{U}$ metal and the costs associated with fabrication of SNF storage and transport container. Existing conversion and fabrication processes are assumed to be used although new and more efficient processes may be available in the near future.

The approach to estimating costs for both alternatives is to identify, compile, and evaluate the existing practices and processes necessary to meet the objectives for each alternative task. For the continued storage alternative, this will consist of acquiring, through documentation and interviews, data on existing storage practices, issues, and needs. For the DU recycle alternative, the approach includes acquisition of all relevant data on existing SNF management activities, preconceptual design of a SNF container using DU, and establishment of functional and performance specifications that would dictate the design of the container and subsequently impact the cost of fabricating the container. 


\section{DU INVENTORY DATA}

As a result of the Energy Policy Act of 1992, which established the United States Enrichment Corporation to handle uranium enrichment activities formerly controlled by DOE, any DU generated by the GDPs after July 1, 1993, will be the responsibility of the United States Enrichment Corporation. DU generated prior to July 1, 1993, will remain under the ownership of DOE. Therefore, for purposes of this report, only the depleted $\mathrm{UF}_{6}$ in storage as of March 1993 at the GDPs is being considered for these management alternatives.

DOE's current inventory of uranium, as of March 31,1993 , is given in Table 1. ${ }^{3}$ Table 1 provides data on quantities of uranium and DU stored within the DOE complex, with depleted $\mathrm{UF}_{6}$ representing $92 \%$ of DOE's total DU inventory of 408,000 MTU. The majority of DOE's depleted uranium is currently in storage at the three GDPs in Paducah, Kentucky; Piketon, Ohio; and Oak Ridge, Tennessee. The $375,000 \mathrm{MTU}$ as depleted UF ${ }_{6}$ remains under the ownership of DOE (i.e., was not transferred to the United States Enrichment Corporation) and represents about $80 \%$ of the total government-owned uranium inventory of 468,000 MTU. Based upon the current inventory of depleted $\mathrm{UF}_{6}$ at the GDPs, 375,000 metric tons of uranium metal are available for the shielding alternative, while 555,000 metric tons of $\mathrm{UF}_{6}$ would presently be available for continued storage. An additional 20,000 and 8,000 MTU of DU exist in the oxide and metal forms, respectively. The breakdown of DOE's DU inventory by storage location as of June 1992 is provided in Table 2. ${ }^{\mathrm{a}}$ At that time, the DU inventories at the Paducah, Portsmouth, and Oak Ridge GDPs were 220,000 MTU, 105,000 MTU, and 36,000 MTU, respectively.

a. Carl Cooley, DOE-HQ/EM-50, Personal Communication with Tim Hertzler, SAIC, January 21, 1993. 
Table 1. Government-Owned Uranium Inventories as of 3/31/93 (MTU)

\begin{tabular}{|c|c|c|c|c|c|}
\hline $\begin{array}{l}\text { Chemical } \\
\text { Form }\end{array}$ & $\begin{array}{c}\text { Depleted } U \\
>0.2 \% \text { to } \\
0.71 \% \text { Assay }\end{array}$ & $\begin{array}{c}\text { Natural } U \\
0.71 \% \text { to } \\
0.712 \% \text { Assay }\end{array}$ & $\begin{array}{l}\text { Low Enriched } \\
>0.712 \% \text { to } \\
20 \% \text { Assay }\end{array}$ & $\begin{array}{l}\text { High } \\
\text { Enriched } \\
>20 \% \text { to } \\
100 \% \text { Assay }\end{array}$ & $\begin{array}{c}\text { Chemical Form } \\
\text { Total MTU }\end{array}$ \\
\hline $\mathrm{UO}_{2}$ & 1 & 1 & 3 & NA & 5 \\
\hline $\mathrm{UO}_{3}$ & 36 & 8 & 694 & 4 & 742 \\
\hline Other Oxides & 19,536 & 1 & 377 & 6 & 19,920 \\
\hline $\mathrm{UF}_{4}$ & 3,192 & 231 & 277 & NA & 3,700 \\
\hline $\mathrm{UF}_{6}$ & 375,204 & $47,724^{a}$ & $5,552^{\mathrm{a}}$ & $11^{\mathrm{b}}$ & 428,491 \\
\hline Alloyed Metal & 2,309 & 108 & 908 & 16 & 3,341 \\
\hline $\begin{array}{l}\text { Unalloyed } \\
\text { Metal }\end{array}$ & 6,127 & 321 & 1,485 & 38 & 7,971 \\
\hline $\begin{array}{l}\text { Nitrate } \\
\text { Solutions }\end{array}$ & NA & NA & 133 & NA & 133 \\
\hline $\begin{array}{l}\text { Other } \\
\text { Misc. }\end{array}$ & 1,308 & 2 & 2,452 & 18 & 3,780 \\
\hline TOTAL & 407.713 & 48,396 & 11,881 & 93 & 468,083 \\
\hline \multicolumn{6}{|c|}{$\begin{array}{l}\text { Includes material transferred to the U.S. Enrichment Corporation. } \\
11 \text { metric tons of highly enriched uranium with assay greater than } 94 \% \text { U-235 to be potentially transferred to U.S. } \\
\text { Enrichment Corporation. } \\
\text { Excess material is not available in this form or assay except in small quantities. }\end{array}$} \\
\hline
\end{tabular}


Table 2. DOE Depleted Uranium Inventory as of $6 / 30 / 92^{\mathrm{a}}$

\begin{tabular}{|c|c|c|c|}
\hline Location & $\underline{\text { U-235 Assay }\left(W_{t} \%\right)}$ & & Weight (kgU) \\
\hline Paducah GDP, MMES, UEA & $<0.21$ & & $73,573,520$ \\
\hline & 0.31 to $<0.50$ & & $59,586,050$ \\
\hline & 0.24 to $<0.26$ & & $51,882,729$ \\
\hline & 0.28 to $<0.31$ & & $28,269,806$ \\
\hline & 0.60 to $<0.711$ & & $2,930,985$ \\
\hline & $<0.21^{b}$ & & $1,831,499$ \\
\hline & 0.26 to $<0.28$ & & $1,128,784$ \\
\hline & 0.21 to $<0.24$ & & 751,960 \\
\hline & 0.50 to $<0.60$ & & 506,479 \\
\hline & & Paducah GDP Total: & $220,461,812$ \\
\hline Portsmouth GDP, MMES, UEA & 0.24 to $<0.26$ & & $39,634,865$ \\
\hline & 0.31 to $<0.50$ & & $35,299,839$ \\
\hline & $<0.21$ & & $20,628,143$ \\
\hline & 0.28 to $<0.31$ & & $4,584,079$ \\
\hline & 0.21 to $<0.24$ & & $2,696,294$ \\
\hline & 0.26 tn $<0.28$ & & $1,670,520$ \\
\hline & & Portsmouth GDP Total: & $104,513,740$ \\
\hline Oak Ridge GDP, MMES, UEA & $<0.21$ & & $22,750,900$ \\
\hline & 0.24 to $<0.26$ & & $9,546,178$ \\
\hline & 0.21 to $<0.24$ & & $1,822,524$ \\
\hline & 0.28 to $<0.31$ & & $1,573,650$ \\
\hline & 0.26 to $<0.28$ & & 682.554 \\
\hline & & Oak Ridge GDP Total: & $36,375,806$ \\
\hline & & GDP TOTAL $(89.82 \%)$ : & $361,351,358$ \\
\hline Westinghouse Env'l Mgt Co. of Ohio & $<0.21^{\mathrm{c}}$ & & $1,716,373$ \\
\hline & $<0.21^{\mathrm{d}}$ & & $1,360,414$ \\
\hline & $<0.21^{\mathrm{c}}$ & & 828,196 \\
\hline & $<0.21^{\mathrm{c}}$ & & 542,749 \\
\hline & & WEMCO Total: & $4,447,732$ \\
\hline Westinghouse Elect. Co., Columbia & $<0.21^{\mathrm{c}}$ & & $3,035,890$ \\
\hline West Hanford, Defense Ops & 0.60 to $<0.711^{f}$ & & 670,188 \\
\hline & & GRAND TOTAL (91.85\%): & $369,505,168$ \\
\hline a. All DU materials listed are from & enriching program, exc & those noted in footnotes $b$ to $f$. & \\
\hline $\begin{array}{l}\text { b. Hex-to-tetrafluoride. } \\
\text { c. } \\
\text { Unirradiated scrap material await }\end{array}$ & recovery. & & \\
\hline d. Reduction. & (n) & & \\
\hline e. DOE program material computer & nerated product. & & \\
\hline Irradiated material awaiting proce & & & \\
\hline
\end{tabular}




\section{CONTINUED STORAGE OF DU}

One of the DU management strategies available to DOE involves the continued storage of the uranium hexafluoride at the GDPs. Since this alternative does not provide for the final disposition of DU, it is primarily being evaluated as an interim management strategy that would allow DOE to safely manage the material as a national strategic resource until an alternative use (such as further enrichment, blending with highly enriched uranium to produce low enriched uranium, feed for an advanced breeder reactor, or shielding purposes) can be identified and implemented. In all likelihood, the continued storage of depleted UF 6 would be used as a management alternative only until the feasibility of future uses of the material can be fully evaluated or, alternatively, until domestic capabilities are developed for the conversion and disposal/storage of the uranium oxide.

\subsection{Regulatory Status/History of DU Storage}

One of the most important factors affecting the continued storage of depleted $\mathrm{UF}_{6}$ at the GDPs will be the regulatory status of the DU. As indicated in other reports, ${ }^{1,2,4,5}$ DOE is currently maintaining the position that the depleted $\mathrm{UF}_{6}$ inventories are "source material" as defined in the Atomic Energy Act of 1954 (AEA), and are, therefore, exempt froin the definitions of solid and hazardous wastes under the Resource Conservation and Recovery Act (RCRA). The Atomic Energy Commission promulgated the regulatory definition of source material in $10 \mathrm{CFR} \S 40.4$ as: "1) Uranium or thorium, or any combination thereof, in any physical or chemical form or 2 ) ores which contain by weight one-twentieth of one percent $(0.05 \%)$ or more of: (i) Uranium, (ii) thorium or (iii) any combination thereof." For a waste to be hazardous waste within the meaning of RCRA, it must first meet the definition of a solid waste. A waste that does not meet the solid waste definition cannot be defined as a hazardous waste. RCRA defines solid waste and hazardous waste as follows:

The term "solid waste" means any garbage, refuse, sludge from a waste treatment plant, water supply treatment plant, or air pollution control facility and other discarded material, including solid, liquid, semisolid, or contained gaseous material resulting from industrial, commercial, mining, and agricultural operations, and from community activities, but does not include solid or dissolved material in domestic sewage, or solid or dissolved materials in irrigation return flows, or industrial discharges which are point sources subject to permits under section 402 of the Federal Water Pollution Control Act, as amended (86 Stat. 880), or source, special nuclear, or byproduct material as defined by the Atomic Energy Act of 1954, as amended (68 Stat. 923). [RCRA § 1004(27)]

The term "hazardous waste" means a solid waste, or combination of solid wastes, which because of its quantity, concentration, or physical, chemical or infectious characteristics may: (a) cause, or significantly contribute to an increase in mortality or an increase in serious irreversible, or incapacitating reversible, illness; or (b) pose a substantial present or potential hazard to human health or the environment when improperly treated, stored, transported, or disposed of, or otherwise managed. [RCRA § 1004(5)] 
In regulations implementing RCRA [40 CFR 261.4(a)], the Environmental Protection Agency (EPA) states the following exclusion: "The following materials are not solid wastes for the purposes of this part: ... (4) Source, special nuclear or byproduct material as defined by the Atomic Energy Act of 1954, as amended, 42 U.S.C. 2011 et seq."

Consistent with these definitions and regulatory exclusions, the depleted $\mathrm{UF}_{6}$ at the GDPs has traditionally been managed as material that was exempt from the regulatory jurisdiction of both the federal EPA and state agencies with respect to hazardous waste requirements under Subtitle C of RCRA. This practice was based upon the position that since the DU consists solely of $\mathrm{UF}_{6}$, it meets the definition of source material and should be regulated strictly under the AEA. The gaseous diffusion process uses $\mathrm{UF}_{6}$ containing $0.71 \%{ }^{235} \mathrm{U}$ as feed material. The feed material, which arrives in cylinders in solid form, is heated in its cylinder to a gaseous state and fed into a cascade consisting of a series of compressors and separation barriers. By physical separation only, the cascade increases the percentage of ${ }^{235} U$ in the "enriched" $U F_{6}$ product stream and decreases the ${ }^{235} \mathrm{U}$ content to less than $0.71 \%$ in the much larger "depleted" $\mathrm{UF}_{6}$ tails stream. This latter stream constitutes the DU that is currently stored at the three GDPs as a resource, primarily because it is still capable of being used as feed material to produce enriched uranium. No chemicals or other materials are added to the $U_{6}$ during the enrichment process or prior to storage of the depleted $\mathrm{UF}_{6}$ in cylinders. ${ }^{b}$ Therefore, the DU does not contain any extranenus "non-AEA" material that would qualify as either a characteristic or listed hazardous waste.

However, in recent years, the issue of the applicability of hazardous waste regulations to DOE's uranium hexafluoride inventories in storage has been raised by the State of Ohio Environmental Protection Agency (OEPA), specifically concerning the DU stored at the Portsmouth GDP in Piketon, Ohio. The Southeast District Office of the OEPA notified DOE in October 1990 that cylinders of depleted $\mathrm{UF}_{6}$ at the Portsmouth GDP were no longer exempt from regulation as hazardous waste under Ohio Administrative Code (OAC) 3745-51-04. ${ }^{\mathrm{c}}$ This section of the Ohio Waste Management Regulations contains the solid waste exclusions comparable to the federal solid waste exclusions of 40 CFR 261.4(a). The federal exclusion for source, special nuclear, or byproduct material has been omitted from OAC 3745-51-04. However, the Ohio Solid and Hazardous Waste Disposal Law, Ohio Revised Code 3734.01(J), does contain the following: ". . Hazardous waste includes any substance identified by regulation as hazardous under the Resource Conservation and Recovery Act of 1976, 90 Stat. 2806, 42 U.S.C. 6921, as amended, and does not include any substance that is subject to the 'Atomic Energy Act of 1954,' 68 Stat. 919, 42 U.S.C. 2011."

The DOE responded in an October 29,1990 , letter from the manager of the DOE Oak Ridge Operations to the Director of the Ohio EPA, 1,6 stating that, "The cylinders of depleted uranium are exempt from regulation because uranium hexafluoride is 'source material' under the Atomic Energy Act of 1954, as amended." In an attached regulatory analysis, DOE's position was

b. Joe LaGrone, Manager DOE Oak: Ridge Operations, letter to Richard Shank, Director Ohio EPA, dated October 29, 1990.

c. Donna Goodman, Inspector Ohio EPA, Division of Solids \& Hazardous Waste Management, letter to Eugene Gillespie, Site Manager U.S. DOE Portsmouth, dated September 27, 1990. 
supported by citing the statutory and regulatory definitions and exclusions within the AEA, RCRA, and the Ohio Revised Code. Additionally, the analysis contained the following:

Source material is clearly a substance that is subject to the AEA. Therefore, depleted uranium, having been defined by the Atomic Energy Commission as a source material is not a hazardous waste under Ohio law.

The depleted uranium stored at PORTS also is not a mixed waste subject to regulation as a hazardous waste, because the depleted uranium is not mixed with a RCRA hazardous waste. There is no other material, waste or otherwise, in the storage cylinder of uranium hexafluoride.

United States Environmental Protection Agency (USEPA) announced its mixed waste policy in the Federal Register on July 3, 1986 (51 FR 24504). That policy ind subsequent clarifications issued by USEPA indicate that USEPA intended to regulate as "mixed wastes" those radioactive materials that become mixed with non-AEA material that is a hazardous waste. Radioactive materials, such as the depleted uranium stored at our Portsmouth facility, that have not been mixed with a non-AEA material that is a hazardous waste are not considered "mixed wastes" regulated by RCRA. See "Guidance on Identification of Low-Level Radioactive and Hazardous Waste," 52 FR 11147.

In summary, the $\mathrm{UF}_{6}$ tails qualify as "source material" under the AEA. Source materials are exempt from regulation under RCRA and Ohio law by statute. USEPA's "mixed waste" policy does not apply to depleted uranium, because this material has not been mixed with a listed hazardous waste or non-AEA material that exhibits a hazardous waste characteristic.

This issue remains unresolved. As of June 1993, DOE's Office of Chief Counsel still had not received any official word from OEPA as to why OEPA believed the depleted $U_{6}$ to be a hazardous waste. Negotiations between OEPA and DOE are continuing. For this report, it has been assumed that the implementation of DOE's enhanced cylinder management program will continue to be regulated strictly under the Atomic Energy Act. This implies that the depleted UF 6 will still qualify as "source material," exempt from RCRA regulation. The validity of this assumption may largely depend upon whether state regulators can be convinced that cylinder storage will be safely and effectively managed until final disposition of the DU is accomplished.

\subsection{Existing Storage Conditions}

Depleted $U_{6}$ has been stored at the GDPs since the mid-1940s, when the first plant to use the gaseous diffusion process for uranium enrichment began operation in Oak Ridge, Tennessee. During this time frame, no major incidents have occurred as a result of the DU storage practices.

d. Dane Bartlett, DOE-ORO Office of Chief Counsel, Personal Communication with Doug Nishimoto, SAIC, June 29, 1993. 
$\mathrm{UF}_{6}$ is a solid material at ambient conditions that reacts readily with moisture in the air to form uranyl fluoride $\left(\mathrm{UO}_{2} \mathrm{~F}_{2}\right)$ and hydrogen fluoride (HF) gas. ${ }^{4}$ In the two known instances where cylinder walls were cracked during handling, the minor breaches tended to self-seal with $\mathrm{UF}_{6}$ reaction products. As a result, the breaches went undetected for several years because the material loss and reaction with atmospheric moisture were so slow. ${ }^{2}$

The depleted $\mathrm{UF}_{6}$ at the three GDPs is typically stored outdoors in steel cylinders with either 10- or 14-ton capacities. The majority of the storage containers are the 14-ton vessels that are designated as thin-wall cylinders and coded as pressure vessels (working pressure rating of 100 psig, with a wall thickness of 5/16 in.). These cylinders currently qualify as "strong-tight containers" for transport of low-specific-activity radioactive materials under Department of

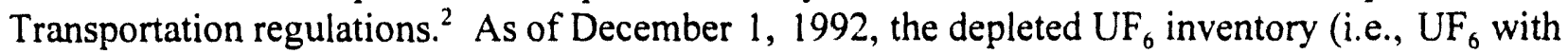
${ }^{235} \mathrm{U}$ assays ranging from 0.05 to $0.71 \%$ ) at the GDPs included 46,707 cylinders with the following breakdown shown in Table 3. An additional 9,100 cylinders containing natural uranium (i.e., with ${ }^{235} \mathrm{U}$ assays between 0.71 and $0.712 \%$ ) were located at the three GDPs. ${ }^{6}$

Typically, the cylinders are stored outdoors on concrete-paved or compacted gravel surfaces in double rows of stacked, two-tier configurations with the lower tier of cylinders placed on wooden or concrete saddles for support above the ground surface. Spacing between adjacent rows of stacked cylinders varies among the three GDP storage sites and also within each GDP. Genera! y, valve ends of the cylinders are separated by about 3 to $4 \mathrm{ft}$, while plug ends are separated by about $1 \mathrm{ft}$. The original intent of this geometric arrangement was to facilitate walk-through access around the cylinder name plates/serial numbers at the valve ends for inventory and accountability requirements. ${ }^{2}$ Approximately 21,000 cylinders (primarily at Paducah and Portsmouth) are inaccessible on the plug ends and cannot be fully inspected. ${ }^{5}$

For the past several years, new cylinder procurement specifications have required a painted surface. However, this original minimal coating of paint (one coat of zinc chromate primer plus one enamel topcoat) has not held up well under outside storage conditions and is extending cylinder life by only a few years, at most. ${ }^{2}$ The significant deterioration of the painted surface and the resulting heavily rusted appearance of some of the new storage cylinders have been studied extensively at the GDPs. These studies indicate that the existing cylinder deterioration/corrosion may not be significant and that the amount and rate of cylinder wall loss should not affect cylinder integrity for 30 to 50 years. ${ }^{4}$ Furthermore, new cylinders should have a service life of as much as 70 years. $^{2}$

Table 3. DU Storage Cylinders as of $12 / 1 / 92$

\begin{tabular}{lrrrr}
\hline Cylinder Type & Paducah & Portsmouth & Oak Ridge & Total \\
\hline 14-ton & 26,114 & 10,990 & 3,212 & 40,316 \\
10-ton & 619 & 2,114 & 1,454 & 4,187 \\
2.5 -ton & 1,087 & 24 & 26 & 1,857 \\
Miscellaneous & 289 & 2 & 56 & 347 \\
\hline Totals: & 28,829 & 13,130 & 4,748 & 46,707 \\
\hline
\end{tabular}


A more recent study (Draft Preliminary Report-DOE Independent $U F_{6}$ Cylinder Assessment Team) has questioned the validity of the cylinder lifetime estimates. ${ }^{5}$ This report maintains that the 30-year remaining life for existing storage cylinders and 70-year lifetime for new cylinders were based upon only general atmospheric corrosion studies that did not account for the more critical factors such as handling/stacking damage and accelerated corrosion due to high moisture conditions or contact with the ground. The ongoing atmospheric corrosion studies have estimated cylinder wall corrosion rates of 1 to 2 mils/yr, while the DOE Cylinder Assessment Report states that cylinder wall loss for cylinders experiencing moisture accelerated corrosion will be at least five times greater and could have corrosion rates as high as $20 \mathrm{mils} / \mathrm{yr}$. Accelerated corrosion rates have been attributed to cylinders in contact with the ground (about 3,700), thin-wall cylinders with skirts that can collect moisture (about 8,300), and thin-wall cylinders with a welded U-shaped channel stiffener that can also collect moisture (about 5,600$){ }^{5}$

Prior to 1990, routine inspections of stored cylinders were not performed. In 1990, during visual inspections to assess valve conditions, two breached cylinders were discovered at the Portsmouth GDP that appeared to be the result of mechanical damage during the stacking operations. An "enhanced" cylinder inspection conducted at the Oak Ridge GDP identified four additional cylinder breaches. Two of these breaches were determined to be caused by impact damage during stacking, while the other two breaches were attributed to accelerated external corrosion caused by storage on the ground. ${ }^{5}$

Based upon findings of the recent cylinder inspection/assessment, approximately $3,000 \mathrm{UF}_{6}$ cylinders at the Oak Ridge GDP, 3,000 at the Portsmouth GDP, and 9,000 at the Paducah GDP have been identified as problem cylinders. Problem cylinders are defined as those having heavily corroded surfaces due to either present or past poor storage conditions or by design (i.e., skirted cylinders), and include all of the Model $\mathrm{T}$ cylinders at the three sites, the cylinders stored at Oak Ridge in K-1066-K, and the bottom row of cylinders in Paducah's C-745-G and F yards. A Kepner-Tregoe Decision Analysis was performed by Martin Marietta Energy Systems, Inc., to evaluate various options for cylinder integrity management at $\mathrm{K}-25$, focusing on the problem cylinders. Based upon a combination of the costs and associated risk ranking, the recommended management alternative involved protecting the problem cylinders by applying either a localized coating or a full-surface coating. e $^{\mathrm{C}}$

Another development of the baseline cylinder inspections was the implementation of a $\mathrm{UF}_{6}$ Long-Term Storage Cylinder Integrity Management Program.' A cylinder management plan was issued in September 1992 to establish methods for sustaining safe storage of the UF 6 until the year 2020, by which time conversion to oxide and subsequent disposal was assumed to commence. This plan established a periodic inspection program for storage cylinders. Breached cylinders are to be inspected daily until a permanent patch is applied or until the $\mathrm{UF}_{6}$ contents are removed. The following cylinders are to be inspected annually:

e. M.F.P. DeLozier, Director MMES Environmental Restoration Program, UF, Cylinder Program: Refinement of "Cylinder Integrity Cost Assessment," letter to Robert Sleeman, Director DOE-ORO Environmental Restoration Division, January 6, 1993. 
1. Cylinders in poor drainage areas. This includes cylinders in or near ground contact and cylinders located in standing water for more than 48 hours after a heavy rain. Dried sludge on the yard surface during dry weather is an indication of poor drainage.

2. Cylinders with scaling rust or localized pitting. These are cylinders with visual indications of accelerated corrosion. To be included in these criteria are Model $T$ and $30 \mathrm{~A}$ cylinders because of their skirt-type design and age.

3. Cylinders with suspect leaking valves/plugs. As determined from the baseline inspection, cylinder valves and plugs with visual indication of contanination will be included in the annual inspections, at a minimum, until the leaks can be verified and contained.

Remaining cylinders and substandard cylinders (initially inspected annually) that have been corrected are to be inspected every four years. The four-year period is based upon (a) the slow, natural deterioration of the cylinder shell from atmospheric corrosion estimated at one mil per year, and (b) information reported from the investigation of breached cylinders at Portsmouth, which indicated that breaches have a relatively slow growth rate and that the loss of uranium compounds is unlikely for at least four years after the initiation of the breach. ${ }^{7}$

\subsection{General Storage Cost Assumptions}

Listed below are the assumptions used for the rough-order-of-magnitude cost estimates for continued storage of DOE's depleted $\mathrm{UF}_{6}$ inventory.

1. Depleted $\mathrm{UF}_{6}$ cylinder storage will continue to be regulated strictly under the Atomic Energy Act and will not be subject to RCRA and/or state hazardous waste regulations.

2. Cylinder storage will continue until the year 2020 , by which time alternative uses will have been identified or domestic capabilities will have been established to convert the $\mathrm{UF}_{6}$ to oxide for subsequent disposal. This extended time frame for storage is based upon a February 20, 1992, DOE position letter. ${ }^{f}$ Although DOE's sshedule for $\mathrm{UF}_{6}$ conversion has since been accelerated, it is felt that storage until 2020 will represent a worst-case scenario for the continued storage option.

3. Costs are based upon 1992 estimates for the K-25 storage cylinders and are therefore given in 1992 dollars. ${ }^{e, g}$ Generally speaking, no reduction in costs has been allowed for economies of scale or for the operation of three similar programs at the GDPs, because any such reductions would likely be offset by the discovery of more problem

f. Philip Sewell, Deputy Asst. Secy. Uranium Enrichment, Plans for Ultimate Disposition of Depleted Uranium, memorandum to Leo Duffy, Director DOE Environmental Restoration and Waste Management, February 20, 1992.

g. Valerie Newman, MMES Cylinder Management Program, Personal Communication with Doug Nishimoto, SAIC, October 26, 1993. 
cylinders at each of the GDPs. One exception to this was made-annual cylinder management costs for Paducah were only tripled compared to K-25 cost estimates ${ }^{g}$ (see item 6 below), even though Paducah stores more than five times the number of cylinders stored at $\mathrm{K}-25$. Individual costs are documented for the following activities:

(a) project integration, general studies, and inspections, (b) capital equipment, (c) operations, (d) new facilities, (e) cylinder handling, and (f) waste management. A range of total costs are then determined using $-10 \%$ and $+40 \%$.

4. Even though costs have been combined, no consolidaion of storage facilities has been assumed. That is, cylinder storage is assumed to continue at all three sites.

5. Problem cylinders at each of the GDPs (3,000 at K-25, 3,000 at Portsmouth, and 9,000 at Paducah, for a total of 15,000 ) will be addressed via full surface preparation and coating.

6. Annual costs for project integration, general studies, and inspections have been assumed to include all DU cylinders within each site, not just the problem cylinders. ${ }^{\mathrm{g}}$ The annual cost of $\$ 3$ million for the first six years includes $\$ 0.5$ million/yr, $\$ 1$ million/yr, and $\$ 1.5$ million/yr for K-25, Portsmouth, and Paducah, respectively. Subsequent program costs of $\$ 1.2$ million/yr for the next 21 years include $\$ 200,000 / \mathrm{yr}$ for K-25, $\$ 400,000 / y r$ for Portsmouth, and $\$ 600,000 / y r$ for Paducah. A total of 8,000 skirted cylinders are assumed to require cleaning every four years, based upon skirted cylinder quantities given in the baseline cylinder inspection report. ${ }^{5}$

7. Capital equipment costs of $\$ 630,000$ are assumed for each GDP to cover purchases of cylinder stackers and straddle carriers. ${ }^{8}$ A total of 15,000 new saddles will be required for the problem cylinders within the three sites.

8. Coating facility operating costs include $10 \mathrm{hrs} /$ problem cylinder, or 150,000 hours. ${ }^{\mathrm{g}}$

9. New facility costs include $\$ 16.5$ million for the design and construction of an automated cleaning/coating facility at each site and new $\$ 750,0001$-acre storage yards for the refurbished cylinders at K-25 and Portsmouth, and a $\$ 2.25$ million 3-acre storage yard at Paducah. ${ }^{\mathrm{g}}$

10. Transporting problem cylinders to the coating facility and then to the new storage yard has been assumed to require $8 \mathrm{hrs} / \mathrm{cylinder} .^{\mathrm{g}}$

11. Waste management costs include 320 B-25 boxes each for K-25 and Portsmouth and 960 B-25 boxes for Paducah. ${ }^{\mathrm{g}}$ 


\subsection{Cost Estimates for Continued Cylinder Storage Until 2020}

A rough-order-of-magnitude cost estimate for the continued storage of $U_{6}$ cylinders at the three GDPs through the year 2020 is provided in Table 4. As previously stated, costs are based upon estimates determined for the K-25 cylinders ${ }^{\mathrm{e}, \mathrm{g}}$ and the assumptions listed in Section 3.3. Life-cycle cost estimates (in 1992 dollars) ranging from $\$ 83$ million to $\$ 129$ million were determined for storing the depleted $\mathrm{UF}_{6}$ through the year 2020. This corresponds to storage costs of $\$ 0.22 / \mathrm{kgU}$ to $\$ 0.34 / \mathrm{kgU}$, using a storage inventory of $375,000 \mathrm{MTU}$.

Table 4. Cost Estimate for Continued Storage of $\mathbf{U F}_{6}$ Cylinders

Cost Element

Project Integration, General Studies, and Inspections:

Daily/annual/4-yr inspections, thickness measurements, valve monitoring, and corrosion monitoring $(\$ 3 \mathrm{M} / \mathrm{yr}$ for first 6 years and $\$ 1.2 \mathrm{M} / \mathrm{yr}$ for next 21 years)

Clean skirted cylinders every 4 yrs $(.5 \mathrm{hr} / \mathrm{skirt} \times 8,000$ cyls $)$

Capital Equipment:

3 cylinder stackers; 3 straddle carriers

15,000 new saddles@\$30/saddle

Operations:

Coating facility operation- $10 \mathrm{hrs} / \mathrm{cylinder}$ [includes surface preparation and coating, documentation of cylinder condition (i.e., thickness measurements, weight, etc.), utilities]

New Facilities:

Construction/design of three automated cleaning/coating facilities

Two 1-acre storage yards and one 3-acre storage yard

Cylinder Handling:

$8 \mathrm{hrs} / \mathrm{cylinder}$ for transportation to coating facility and then to new storage yard (includes visual inspections and health physics checks)

Waste Management:

1,600 B-25 boxes@ @1,800/box (includes $15 \mathrm{lb}$ rust and paint, sampling and analysis, old saddle disposal)

TOTAL:

92,410

RANGE OF TOTAL COSTS $(-10 \%$ and $+40 \%)$ : 


\section{DU SHIELDED SPENT NUCLEAR FUEL CONTAINER}

The feasibility of using the DU as radiation shielding in a SNF package is evaluated in this section. This preliminary assessment is based on existing conversion and fabrication process technologies, vendor quotes, and data sbtained directly from multiple literature sources. A firstorder DU metal package design was conceptualized for the purpose of cost estimating. Preliminary calculations were performed for radiation shielding needs and structural capability to withstand a hypothetical tip-over accident. The envisioned package concept is assumed to be licensable; however, additional design detail will be required to verify the licensability prospects, of any DU package concept. This chapter describes the major process steps, regulatory requirements, and estimated costs associated with converting the $\mathrm{UF}_{6}$ to uranium metal and fabrication of a SNF container as currently conceptualized. A general comparison was made between the DU shielded SNF package concepts and current multi-purpos ${ }^{\circ}$ canister (MPC) concepts being evaluated by the DOE's Office of Civilian Radioactive Waste Management (OCRWM) and its management and operations (M\&O) contractor, TRW Inc.,

\subsection{Background}

With the passage of the Nuclear Waste Policy Act (NWPA) of 1982 and subsequent amendments in 1987, Congress set forth a plan to manage the nation's SNF and high-level waste (HLW). The OCRWM was set up within DOE to administer this plan. The OCRWM initiated the Civilian Radioactive Waste Management System (CRWMS), which consists of the following four elements for handling the nation's SNF/HLW:

- Waste Acceptance - Process of transferring SNF from the nuclear utilities to DOE

- $\quad$ Storage - Process of siting, construction, operation, and eventual decommissioning of a monitored retrievable storage (MRS) facility

- Transportation - Process of establishing the infrastructure needed to transport the SNF/HLW to either the MRS or a mined geologic dispusal (MGD) facility

- Disposal - Process of safe long-term isolation of the SNF/HLW in a MGD.

From the onset of the CRWMS activities in the early 1980s, the baseline SNF management scenario consisted of multiple handling of bare spent fuel assemblies. As a minimum, the fuel assemblies are handled once at the reactor when loaded into conventional transportation casks for shipment to a MRS facility or MGD. However, for the reactors exceeding their spent fuel pool capacities, interim dry storage at-reactor prior to shipment of the fuel to an MRS would require handling the bare fuel a minimum of two times; once for in-pool loading into a storage cask and once to transfer the spent fuel into a transportation cask. At the MRS, the bare fuel assemblies would again be handled a number of times, including removal from the transportation cask, then interim storage and possible consolidation of the fuel rods at the MRS, prior to reloading the fuel into repository waste packages. This handling would occur under the initial management scenarios. This increased handling of the bare SNF assemblies increases the potential for radiation exposures, accidental releases of radioactive materials, and attendant handling and 
operational costs. Additionally, the initial MGD site characterization plan adopted a corrosion resistant thin-walled container as the anticipated waste package design. This waste package, which was approximately $2 \mathrm{ft}$ in diameter and $15 \frac{1}{2} \mathrm{ft}$ long, would be emplaced in boreholes in the floors of underground access drifts. This waste package configuration does not provide any radiation shielding; thus, shielded handling, transport, and emplacement would be required. In trying to address these concerns, new approaches to SNF management have evolved since the initial site characterization plan phase of the CRWMS.

The newest philosophy, resulting in part from a Secretary of Energy mandate to integrate the SNF management system, was to evaluate a more robust package design that could serve multiple purposes (i.e., storage, transportation, and disposal) within the CRWMS. The new evolution in package concepts focused attention on a large waste package which, rather than being placed in a borehole, would be placed in-drift in the MGD. As a result, the OCRWM is currently evaluating various MPC concepts. The MPC concept objectives are to provide a SNF package that, once loaded at the reactor, would meet storage, transportation, and disposal functions in a single package, thus eliminating subsequent fuel transfer activities. Currently, two preliminary package designs have been conceptualized by OCRWM: ${ }^{9}$

- A 125-ton MPC

- A 75-ton MPC.

Both package concepts use an inner thin-walled container as the MPC with separate overpacks optimized for storage, transportation, and disposal functions. As an alternative to an MPC concept, OCRWM also conceptualized a multi-purpose unit (MPU), which performed all three functions (i.e., storage, transportation, and disposal) in a single package configuration. The DU shielded package conceptualized here could be a double-element (i.e., inner container with overpacks-MPC) or a single-element (i.e., MPU) type package. However, for preliminary assessment, the DU package was assumed to be a single-eiement package with an external removable neutron shield as described in Section 4.6.3.

\subsection{Quantities and Characteristics of Spent Nuclear Fuel}

\subsubsection{Quantities and Description}

The primary source of SNF for repository emplacement is commercial light-water reactor (LWR) fuels, which are not typically reprocessed once removed from the reactors. As of December 1, 1990, there were approximately 80,000 LWR fuel assemblies that have been discharged from commercial power reactors. ${ }^{10}$ These 80,000 LWR assemblies represent approximately 22,000 metric tons of initial heavy metal (MTIHM). The projected inventories in LWR fuel assemblies beyond those currently in storage are estimated based on three scenarios describing the future operation of nuclear power plants in the U.S.: ${ }^{10,11}$

1. No new orders (NNO) case

2. Lower reference case 


\section{Upper reference case.}

The NNO consists of existing nuclear plants and nuclear power generating units in the construction pipeline (i.e., committed and likely to go on line) as of December 31, 1986. This case gives an intermediate value of projected fuel discharges between that of the lower and upper reference cases. Based on NNO, the total projected discharge of fuel assemblies (including those already in storage) through 2040 is approximately 294,618 assemblies. The total weight of these assemblies amounts to 86,050 MTIHM.

Characterization of this SNF is based primarily on assembly type and model broken down in terms of intact fuel assemblies, spent fuel disassembly hardware, defective fuel, special forms, and nonfuel assembly hardware. Only intact fuel assemblies are used as the basis for assessments performed in this study. The two main assembly types are defined by the type of reactor using the fuel; the boiling water reactor and the pressurized water reactor assemblies. The differences between the BWR and PWR fuel are significant and sufficient to maintain distinction throughout the spent fuel management system. Of the total inventory of LWR SNF, approximately $65 \%$ (by weight) is of the PWR type and $35 \%$ (by weight) is of the BWR type. ${ }^{10}$ Fuel assembly inventories by numbers are 131,838 PWRs and 162,780 BWRs. ${ }^{9}$

In general, PWR assemblies are significantly larger than the BWR assemblies and contain more fuel per assembly; however, the configuration is essentially the same. The uranium oxide $\left(\mathrm{UO}_{2}\right)$ fuel pellets are placed within fuel rods (e.g., zirconium alloy) and arranged in a square array. Structural components hold the array of fuel rods together. The fuel assemblies used in this study are the Babcock and Wilcox (B\&W) $15 \times 15$ PWR and the General Electric (GE) $8 \times 8$ BWR. These fuel assemblies were used as the design basis fuel assemblies in the recent B\&W Fuels Company Preliminary Design Report for the new generation rail/barge transportation cask known as the BR-100. ${ }^{12}$ The design basis fuel parameters are summarized in Table 5. The radioactive source term generated for these assemblies in the B\&W report was directly used in radiation transport models, as detailed in Section 4.7, to determine DU shielding requirements for an SNF package. The radioactive source term is described in Appendix A.

\subsection{Spent Nuclear Fuel Storage and Transportation Regulations}

The Nuclear Regulatory Commission (NRC) and the U.S. Environmental Protection Agency have issued regulations that control the storage, transportation, and disposal of SNF and HLW. Storage of SNF is regulated under Title 10 Code of Federal Regulations (CFR) Part 72 [10 CFR 72], "Licensing Requirements for the Independent Storage of Spent Nuclear Fuel and High-Level Radioactive Waste." The transportation of SNF/HLW is regulated under 10 CFR 71, "Packaging and Transportation of Radioactive Material." Disposal of the SNF/HLW in the MGD is regulated under 10 CFR 60, "Disposal of High-Level Radioactive Wastes in Geologic Repositories," and 40 CFR 191, "Environmental Radiation Protection Standards for Management and Disposal of Spent Nuclear Fuel, High-Level, and Transuranic Radioactive Wastes."

The CRWMS MPC, in combination with its respective overpack(s), will be required to meet the regulatory criteria set forth in $10 \mathrm{CFR} 72,71$, and 60 for storage, transportation, and disposal respectively. A SNF package that is multi-purpose/single-element (i.e., integral storage, transport 


\begin{tabular}{|c|c|c|}
\hline & $\underline{\text { PWR }}$ & $\underline{B W R}$ \\
\hline Assembly Array & $B \& W-15 \times 15$ & G.E. $-8 \times 8$ \\
\hline Assembly Weight, $\mathrm{lb}$ (Nominal) & 1,515 & 587 \\
\hline Fuel Assembly Length, in & 165.625 & 175.5 \\
\hline Active Fuel Length, in & 143 & 138 \\
\hline Number Of Fuel Rods/assembly & 208 & 62 \\
\hline Fuel Rod Diameter, in & 0.430 & 0.483 \\
\hline Cladding Material & Zircaloy-4 & Zircaloy-2 \\
\hline Cladding Thickness, in & 0.0265 & 0.030 \\
\hline Pellet Diameter, in & 0.36861 & 0.410 \\
\hline Pellet Materiaì & $\mathrm{UO}_{2}$ (Sintered) & $\mathrm{UO}_{2}$ (Sintered) \\
\hline Pellet Theoretical Density, & $95^{\circ}$ & 94.5 \\
\hline Max. Initial Enrichment. \% by wt.U-235 & 3.0 & 3.0 \\
\hline Design Basis Burnup, \% MWd/MTU-235 & 35,000 & 30,000 \\
\hline Weight of Uranium, $\mathrm{kg} /$ Assembly & 465 & 176.8 \\
\hline Minimum Decay Time, yr & 10 & 10 \\
\hline
\end{tabular}

and disposal container-MPU) will need to meet 10 CFR 71, 72, and 60 requirements in a single-element configuration. It is expected that licensing of a MPU will be more difficult than the MPC concept since it must meet each of the regulatory criteria in a single package. This will be the case for any DU shielded package designed as an MPU configuration as well. However, as indicated in Section 4.1, the DU container conceptualized here can be designed as an MPC type of package if regulatory restrictions prove too difficult to overcome in a MPU configuration.

The primary criteria established by these statutory regulations, which were addressed in the preliminary design of the DU package in Section 4.6, are as follows:

- 10 CFR $\S 71.47$ radiation limits of $10 \mathrm{mrem} / \mathrm{hr}$ (gamma plus neutron) dose at $2-\mathrm{m}$ distance and $200 \mathrm{mrem} / \mathrm{hr}$ (gamma plus neutron) dose on the container surface

- Structural containment for a normal accident condition in a storage mode based on stringent American Society of Mechanical Engineers (A.SME) Boiler and Pressure Vessel Code requirements

- Physical constraints on weights and dimensions for at-reactor handling and transport.

Additional discussion and a listing of federal regulations, standards, and regulatory guidelines applicable to SNF storage, transportation, and safety analysis reports (SAR), are provided in greater detail in Appendix B. 


\subsection{Conversion of $\mathrm{UF}_{6}$ to Uranium Metal}

\subsubsection{Process Description}

The conventional conversion process, commonly known as the Ames process, employed for $U_{6}$ reduction to $U$ metal is shown in Figure 1. The reduction is performed in two steps: first, the $\mathrm{UF}_{6}$ is converted to $\mathrm{UF}_{4}$ (greensalt) using a hydrogen reduction reaction, and second, the $\mathrm{UF}_{4}$ is converted to $U$ metal using a batch thermite reduction reaction. ${ }^{\text {h, }}$

The first reduction reaction (reaction 1 below) is typically performed in a flame tower using pure hydrogen gas $\left(\mathrm{H}_{2}\right)$ as the reactant. ${ }^{\text {h }}$ The solid $\mathrm{UF}_{6}$ in the existing storage cylinders is heated under pressure to form gaseous $\mathrm{UF}_{6}$. This $\mathrm{UF}_{6}$ gas is fed into the flame tower along with $\mathrm{H}_{2}$. The reduction reaction results in production of an anhydrous hydrogen fluoride (HF) gas and the $\mathrm{UF}_{4}$ product, which is the feed for the second reduction reaction step. The second reduction process involves blending the $\mathrm{UF}_{4}$ with a high grade of chipped magnesium and applying heat to initiate the second reduction reaction (reaction 2 below). The reaction ignition temperature is nominally $1,080^{\circ} \mathrm{F}$. Once initiated, the spontaneous exothermic reaction is sufficient to reduce the reactants to molten uranium metal and magnesium fluoride $\left(\mathrm{MgF}_{2}\right)$. The higher-density uranium collects in the bottom of the vessel and the lighter $\mathrm{MgF}_{2}$ accumulates on the top. The uranium metal debris removed from the reaction vessel after cooling is typically transferred to a remelt area for alloying and casting operations, and the $\mathrm{MgF}_{2}$ that contains residual uranium contamination is a waste by-product requiring disposal.

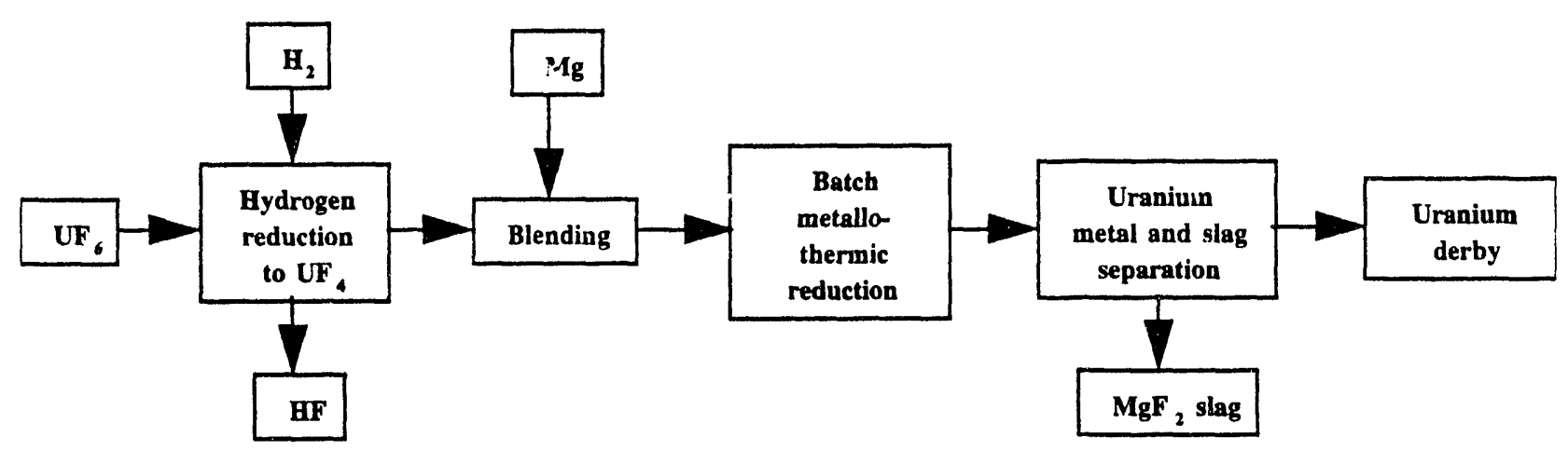

Figure 1. Conventional Batch Process for Uranium Metal Production

h. J. Ellis, Sequoyah Fuels Corporation, Personal Communication with T. Hertzler, SAIC, April 1993.

i. W. Christian, Aerojet Ordnance Tennessee, Personal Communication with T. Hertzler, SAIC, May 1993. 
Reaction 1. $\mathrm{UF}_{6}+\mathrm{H}_{2}=\mathrm{UF}_{4}+2 \mathrm{HF}$

Reaction 2. $\mathrm{UF}_{4}+2 \mathrm{Mg}=\mathrm{U}$ metal $+2 \mathrm{MgF}_{2}$

\subsubsection{Process Mass Balance}

Based on the Ames process described above, a stoichiometric mass balance was performed to define the mass relationships between inputs, reactants, intermediates, and products. The resulting mass fractions (i.e., unit mass products per mass of feed) are listed in Table 6.

The most important results from the mass balance are the quantities of HF, $U$ metal, and $\mathrm{MgF}_{2}$ produced from the $\mathrm{UF}_{6}$ input. Stoichiometrically, for every kilogram of $\mathrm{UF}_{6}$ input into the process, $0.114 \mathrm{~kg}$ of $\mathrm{HF}, 0.676 \mathrm{~kg}$ of $\mathrm{U}$ metal, and $0.354 \mathrm{~kg}$ of $\mathrm{MgF}_{2}$ will be produced. Assuming the total inventory of $555,000 \mathrm{MT}$ of $\mathrm{UF}_{6}$ is fed to the conversion $\mathrm{p}$ ocess, the resulting quantities of HF, uranium metal, and secondary waste would be 63,270 MT, $375,000 \mathrm{MT}$, and 196,500 MT, respectively. The mass of DU metal used to fabricate individual DU shielded SNF containers and cost and credit estimates associated with resale and disposal of the by-products are detailed in Sections 4.6.4 and 4.8.1.

\subsubsection{Secondary Waste}

As indicated above, the secondary product from the conversion process (i.e., $\mathrm{MgF}_{2}$ ) is considered a waste. Commercial uranium conversion and fabrication facilities (e.g., Aerojet Ordnance Tennessee) are licensed by the NRC to dispose of this material in a sanitary landfill if the residual radioactivity is less than 35 picocuries per gram $\left(\mathrm{pCi} / \mathrm{g}\right.$ ) of material. ${ }^{i}$ It is not known at this time if the full-scale conversion and fabrication of SNF containers with the subsequent high mass of $\mathrm{MgF}_{2}$ (i.e., 196,500 MT) would still be disposed of in this manner. It is assumed for this report that the large mass of $\mathrm{MgF}_{2}$ could not be disposed of in a sanitary

Table 6. Depleted Uranium Stoichiometric Mass Balance

\begin{tabular}{|c|c|c|}
\hline INPUT DU & 1 mass unit & As $U$ metal 1 mass unit \\
\hline \multicolumn{3}{|l|}{ REACTANTS } \\
\hline $\mathrm{H}_{2}$ & 0.00574 & 0.00849 \\
\hline $\mathrm{Mg}$ & 0.138 & 0.204 \\
\hline \multicolumn{3}{|l|}{ INTERMEDIATES } \\
\hline $\mathrm{UF}_{4}$ & 0.892 & 1.319 \\
\hline $\mathrm{HF}$ & 0.114 & 0.168 \\
\hline \multicolumn{3}{|l|}{ PRODUCTS } \\
\hline $\mathrm{MgF}_{2}$ & 0.354 & 0.5236 \\
\hline U-238 (metal) & 0.676 & 1 \\
\hline
\end{tabular}


landfill, but would need to be disposed of as a low-level waste (LLW) in a radioactive-permitted disposal facility instead.

The costs associated with disposal of this material as LLW are factored into the cost of converting the $\mathrm{UF}_{6}$ to $\mathrm{U}$ metal and are included in Section 4.8.1. The intermediate product (anhydrous HF) is considered to be recyclable back into the uranium ore to $\mathrm{UF}_{6}$ conversion process. Allied Signal Inc., a primary uranium ore conversion company, currently recycles the anhydrous $H F$ recovered from existing $U_{6}{ }_{6}$ to $U F_{4}$ conversion processes. ${ }^{\text {h, } 13}$ This recycling of the $\mathrm{HF}$ is considered an economic benefit, which will help offset the cost of conversion. Currently, Allied Signal has indicated that it could use all the HF generated during the conversion process; the HF would have an approximate resale value of $\$ 1.43 / \mathrm{kg}$. ${ }^{13}$ This credit is accounted for in developing the preliminary cost associated with the conversion of $U_{6}$ to $U$ metal in Section 4.8.1.

\subsection{Characteristics and Properties of DU Metal}

The feasibility of using the DU in a SNF container depends in large part on the benefits gained from the material properties of the DU metal. The beneficial properties of uranium metal for shielding gamma radiation are well established. Uranium metal, with its high density (i.e., $18.7 \mathrm{~g} / \mathrm{cc}$ ) and high atomic number, is an ideal material for attenuating photon radiation. It has been used in numerous applications (e.g., transportation casks, accelerator absorber plates, etc.) in the past for this reason. However, its ability to moderate and capture neutron particles emanating from the SNF is poor. Other properties of DU metal of interest in a SNF container application are the thermal, mechanical, and corrosion properties.

\subsubsection{Radiation Shielding Properties}

\section{Photon Shielding}

For gamma ray attenuation, the $U$ metal is a very good material. Its linear attenuation coefficient compared to other materials including lead is shown in Table $7 .^{14}$ Attenuation of the gamma radiation is described by a simple intensity equation:

$$
\begin{aligned}
I=I_{0} \mathrm{e}^{-\mu t} \text { where: } \quad \mathrm{I}_{0} \quad \begin{array}{l}
\text { gamma-ray intensity at zero absorber thickness } \\
\mathrm{t}
\end{array} & =\text { absorber thickness } \\
\mathrm{I} & =\text { gamma-ray intensity transmitted through an absorber of } \\
\mu & =\text { thickness } \mathrm{t}
\end{aligned}
$$

The relative thickness of DU metal compared to that of $10 \mathrm{~cm}$ of lead, without considering buildup factors, at various quantum energies is shown in Table 8.

\section{Neutron Shielding}

Neutrons are classified according to their energy. High-energy neutrons, those whose energy exceeds about $0.1 \mathrm{MeV}$, are called fast neutrons. Thermal neutrons, on the other hand, have the 
Table 7. Linear Attenuation Coefficients

\begin{tabular}{lcccccccccccc}
\hline & & \multicolumn{10}{c}{ Quantum Energy, MeV } \\
\cline { 3 - 12 } & $\rho, \mathrm{g} / \mathrm{cm}^{3}$ & 0.1 & 0.15 & 0.2 & 0.3 & 0.4 & 0.5 & 0.6 & 0.8 & 1.0 & 1.5 \\
\hline $\mathrm{Al}$ & 2.7 & 0.435 & 0.362 & 0.324 & 0.278 & $\mathrm{NA}$ & 0.227 & $\mathrm{NA}$ & 0.185 & 0.166 & 0.135 \\
$\mathrm{Fe}$ & 7.9 & 2.72 & 1.445 & 1.090 & 0.838 & $\mathrm{NA}$ & 0.655 & $\mathrm{NA}$ & 0.525 & 0.470 & 0.383 \\
$\mathrm{Cu}$ & 8.9 & 3.80 & 1.830 & 1.309 & 0.960 & $\mathrm{NA}$ & 0.730 & $\mathrm{NA}$ & 0.581 & 0.520 & 0.424 \\
$\mathrm{~Pb}$ & 11.3 & 59.7 & 20.8 & 10.15 & 4.02 & $\mathrm{NA}$ & 1.64 & $\mathrm{NA}$ & 0.945 & 0.771 & 0.579 \\
Concrete & 2.35 & 0.397 & 0.326 & 0.291 & 0.251 & $\mathrm{NA}$ & 0.204 & $\mathrm{NA}$ & 0.166 & 0.149 & 0.122 \\
Uranium & 18.7 & 35.72 & 47.87 & 23.94 & $\mathrm{NA}$ & $\mathrm{NA}$ & $\mathrm{NA}$ & $\mathrm{NA}$ & 1.86 & 1.45 & 1.02 \\
& & & & & & & & & & & \\
\hline
\end{tabular}

Table 8. Thickness of Uranium Shield Equivalent to $10 \mathrm{~cm}$ of Lead

\begin{tabular}{ccccccccccccc}
\hline Thickness \\
\cline { 2 - 11 } $\begin{array}{c}\text { of Uranium } \\
(\mathrm{cm})\end{array}$ & 0.1 & 0.15 & 0.20 & 0.30 & 0.40 & 0.50 & 0.60 & 0.80 & 1.0 & 1.5 \\
& 17.24 & 4.69 & 4.72 & NA & 4.92 & NA & 5.22 & 5.41 & 5.56 & 5.75 \\
& & & & & & & & & & & &
\end{tabular}

same kinetic energy as gas molecules in their environment. Fast neutrons are not easily stopped or captured by shielding materials until they are moderated (i.e., slowed down) to thermal energies. Since all neutrons, at their birth, are fast neutrons, and fast neutrons generally lose their energy by colliding elastically with atoms in their environment, then moderation and attenuation of the neutrons is most effectively accomplished using a material high in hydrogen atoms. This is because the hydrogen nucleus and the neutron particle are of similar mass, and an elastic collision between the two results in a much higher energy transfer than is possible with elements with heavier nuclei (e.g., uranium). The theoretical energy transfer for a head-on collision between a fast neutron and a nucleus of hydrogen versus that of uranium can be calculated using the conservation laws of energy and momentum (Equation 1). The energy transferred to the target nucleus is $E_{0}-E$ as given in Equation $2 .^{14}$

$$
\begin{aligned}
& E=E_{0}(M-m / M+m)^{2} \\
& E_{0}-E=E_{0}\left[1-(M-m / M+m)^{2}\right]
\end{aligned}
$$

where: $\quad E_{0}=$ energy of incident neutron

$\mathrm{m}=$ mass of the incident neutron

$\mathrm{M}=$ mass of the scattering nucleus

Using Equation 2 and the respective masses of scattering nuclei, it can be shown that the maximum fraction, $\left(E_{0}-E\right) / E_{0}$, of the neutrons kinetic energy that is transferred during a single collision to the scattering nucleus is approximately $1.0(100 \%)$ for hydrogen compared to only $0.0168(1.68 \%)$ for uranium. This shows that on a "per collision" basis, nuclei with small mass 
numbers are much more effective for moderating fast neutrons. One drawback to moderating fast neutrons with hydrogen is the secondary generation of a gamma ray by the reaction ${ }^{1} \mathrm{H}(\mathrm{n}, \gamma) \mathrm{H}^{2}$. This secondary gamma must than be attenuated within the package to minimize radiation doses.

For an all-metal SNF package, alloying with an element such as boron may increase the moderation and neutron capturing potential. The maximum theoretical fraction of energy transfer from a fast neutron for a head-on collision with a boron nucleus is approximately $31 \%$. Additionally, boron $10(\mathrm{~B}-10)$ has a very high absorption cross section of $4.01 \mathrm{E}+3$ barns for capturing the neutron, once thermalized. The boron capture reaction $\left[{ }^{10} \mathrm{~B}(\mathrm{n}, \alpha)^{7} \mathrm{Li}\right]$, unlike the hydrogen reaction, does not release a gamma ray but instead releases an alpha particle that is very easily attenuated. A parametric study of the benefits of alloying the metal with boron was not performed as a part of this preliminary assessment. However, in developing the conceptualized DU shielded package in this study it was determined that, although a poor neutron shield, $U$ metal is approximately $40 \%$ better at attenuating fast neutrons than stainless steel (see Section 4.7.1).

\subsubsection{Mechanical and Thermal Properties}

Uranium metal is not a certified American Society of Testing and Materials (ASTM) structural material; however, it does have inherent mechanical/structural properties (especially if alloyed) comparable to stainless steels. Table 9 lists some measured and documented mechanical properties of uranium, stainless steel, and carbon steels for comparison purposes. However, since the uranium is not currently accepted as a structural material by American Society of Mechanical Engineers, it is not acceptable as a structural component in a SNF container. Therefore, it will be necessary to use steel (typically stainless steel) as the structural component of the container, in combination with the uranium. For this study, evaluations were made on SNF packages fabricated from uranium to the maximum extent possible without taking credit for its structural/mechanical properties. Stainless steel and high nickel alloys (i.e., Alloy 825 ) were used in conjunction with uranium metal for required structural strength and increased corrosion resistance. If DU metal qualified as an ASTM structural material, the mass of the SNF package could feasibly be reduced, and a resulting increase in SNF capacity per package may be gained.

A preliminary assessment of the reduction of package mass using DU in combination with steel indicates that, for the package concept used in this study (i.e., 21 PWRs), a $11 \%$ decrease in weight resulted if structural credit were taken for the DU metal. This corresponds to a similar assessment done by Sandia National Laboratory, where structural credit was taken for DU metal in the General Atomic (GA) legal weight truck transportation cask known as the GA-4. ${ }^{15}$ The Sandia assessment indicated that a $10 \%$ weight savings was gained in the mass of the cask without impact limiters or fuel. A series of parametric studies, detailing the cost versus benefits of certifying DU metal as an ASTM structural material for use in multi-purpose SNF containers, would show whether the savings outweigh the costs. 
Table 9. Material Properties

\begin{tabular}{|c|c|c|c|c|c|c|c|c|}
\hline \multirow[b]{2}{*}{ Material } & \multirow[b]{2}{*}{ Type } & \multirow[b]{2}{*}{$\begin{array}{l}\text { Density } \\
g / c c \\
{[[\mathrm{~b} / \mathrm{in} 3]}\end{array}$} & \multicolumn{4}{|c|}{ Mechanical Properties } & \multicolumn{2}{|c|}{ Thermal Properties } \\
\hline & & & $\begin{array}{c}\text { Min. } \\
\text { Tensile } \\
\text { Strength } \\
\text { (Su) (ksi) }\end{array}$ & $\begin{array}{l}\text { Min. Yield } \\
\text { Strength } \\
\text { (Sy) (ksi) }\end{array}$ & $\begin{array}{c}\text { Elong./Red. } \\
\text { Area (\%) }\end{array}$ & $\begin{array}{c}\text { Fracture } \\
\text { Toughness } \\
(\mathrm{MPa}-\sqrt{\mathrm{m}}) \\
\end{array}$ & $\begin{array}{l}\text { Thermal } \\
\text { Conductivity } \\
(\mathrm{k})\left(\mathrm{w} / \mathrm{m} \cdot^{\circ} \mathrm{C}\right) \\
{\left[\mathrm{BTU} / \mathrm{hr} \cdot \mathrm{ft}-{ }^{-} \mathrm{F}\right]}\end{array}$ & $\begin{array}{c}\text { Thermal } \\
\text { Diffusivity } \\
{[\mathrm{f} 2 / \mathrm{hr}]}\end{array}$ \\
\hline $\begin{array}{l}\text { Austenitic } \\
\text { Stainless } \\
\text { Steel" }\end{array}$ & $\begin{array}{l}304 \mathrm{~L} \\
\text { Place }\end{array}$ & $\begin{array}{c}8.02 \\
{[0.289]}\end{array}$ & $75^{\circ}$ & $30^{\circ}$ & 60/NA & NA & $\begin{array}{c}14.8^{4} \\
{[10.4]}\end{array}$ & $\overline{0.165^{\circ}}$ \\
\hline $\begin{array}{l}\text { U-Metal } \\
\text { (alloyed } \\
w / 1.7 \% \\
\mathrm{Nb})^{b}\end{array}$ & Cast Heat I & $\begin{array}{c}18.7 \\
{[.683]}\end{array}$ & 142 & 69 & $24.3 / 28$ & 151 & NA & NA \\
\hline $\begin{array}{l}\text { U-Metal } \\
\text { (unalloyed) }\end{array}$ & $\begin{array}{c}\text { Cast Heat } \\
\text { F }\end{array}$ & $\begin{array}{c}18.7 \\
{[.683]}\end{array}$ & 62 & 29 & $5.5 / 9.7$ & 171 & $28.0^{4}$ & NA \\
\hline $\begin{array}{l}\text { U-Metal } \\
\text { (unalloyed; } \\
\alpha \text {-rolled: } H \\
\text { outgased) }\end{array}$ & plate & $\begin{array}{c}18.7 \\
{[.683]}\end{array}$ & 104 & 39 & $31 / 52$ & NA & NA & NA \\
\hline $\begin{array}{l}\text { Mild Steel } \\
(1020 \text { as- } \\
\text { rolled })^{\mathrm{c}}\end{array}$ & plate & $\begin{array}{c}6.92 \\
{[0.250]}\end{array}$ & 65 & 48 & $36 / 59$ & NA & $30.9^{4}$ & $0.572^{\circ}$ \\
\hline
\end{tabular}

a. 1992 ASME Boiler and Pressure Vessel Code, Section II Materials, Pan D, Properties.

b. R. Salzbrenner et al., "Structural Credit for Depleted Uranium Used in Transpor Casks," High-Level Waste Management Conference Proceedings, 1992, pp 2241-2248.

c. S. Kalpakjian, Manufacturing Process for Engineering Materials: Table 3.8, Page 147.

d. Perry \& Chilton, Chemical Engineering Handbook, Fifth Edition, 1963.

NA Data not directly available or calculated.

\subsection{Preliminary DU Shielded Package Concept}

\subsubsection{Assumptions and Design Constraints}

In an effort to parallel the latest CRWMS philosophy and to maximize the SNF capacity per container, a large (i.e., 21 PWR) all-metal and fully shielded package was originally considered. Due to the poor neutron shielding capability of steel and uranium, the all-metal 21-PWR package exceeded weight limits for handling and transport. Therefore, an alternative SNF package using a removable neutron shield of polyethylene was conceptualized.

The primary driver behind designing a package made strictly from metal or with a removable neutron shield is the current MGD waste acceptance parameters that restrict the allowable shielding materials that can be placed in the repository. Shielding materials likely to be restricted are lead and hydrogenous materials. Lead may not be acceptable for shielding in MPCs/MPUs due to long-term performance concerns and the fact that it may cause the package to be classified as a "mixed waste." Similarly, hydrogenous materials could not be used for neutron moderating material due to the potential flammability and radiolytic hydrogen production. $^{8}$ As discussed in Section 4.7.1, even though $U$ metal is approximately $40 \%$ better 
than stainless steel at attenuating fast neutrons, it is still very poor at shielding neutron radiation when compared to hydrogenous materials. Thus, exceedingly thick wall sections are required to attenuate the neutron radiation, and package weight limits are exceeded in large waste packages.

\section{Preliminary Design Constraints}

Some important design constraints, placed on previous contract statements of work for vendors participating in the OCRWM's cask development program and draft purchase specifications for dual-purpose casks at the Sacramento Municipal Utility District Rancho Seco nuclear facility, are as follows:

- Casks shall be optimized for a reference SNF age (time after reactor discharge) of 10 years

- Cask design shall be optimized for PWR fuel burnups of 35,000 MWD/MTU and BWR fuel burnup of 30,000 MWD/MTU

- The rail/barge cask crane hook weight, which includes the lifting yoke and interstitial water from pool loading operations, shall not exceed $200,000 \mathrm{lb}$ (100 tons)

- The gross vehicle weight of the rail/barge cask plus rail car shall not exceed 263,000 lb (131.5 tons)

- The cask supplier shall provide the analysis demonstrating that the cask containment and shielding is designed such that the radiological criteria of 10 CFR $\S 72.104$, and $\S 72.106$, and 10 CFR $\$ 71.47$ are met for normal and hypothetical accident conditions of storage and transportation, respectively

- Structural constraints shall meet the 10 CFR 71 [§§ 71.71 and 71.73] for normal and accident conditions of transport

- Containment boundary materials shall be listed in ASME Boiler and Pressure Vessel Code, Section II and design and fabrication shall meet the requirements of ASME Boiler and Pressure Vessel Code Subsection NB

- Under optimum internal and external moderation and reflection conditions, the $\mathrm{K}$ effective of the cask and an array of casks shall not exceed 0.95 at 2-sigma upper limit including all positive biases

- The cask heat dissipation capabilities shall limit the temperature of the hottest fuel assembly to $340^{\circ} \mathrm{C}$ under the most severe thermal conditions.

This list is by no means all inclusive; however, it provides the basis for a preliminary assessment of the DU package concept presented here. The constraints on SNF age and burnup are accounted for in the selection of the design basis fuel from the B\&W BR-100 Preliminary Design Report. Weight constraints were taken into account in conceptualizing the DU package 
with a removable neutron shield rather than an all metal package. The radiation shielding constraints are addressed in Section 4.7.1, preliminary shielding analysis. Containment boundary structural constraints were calculated for a storage scenario tip-over accident with the allowable stresses for the construction materials being drawn from the appropriate ASME Boiler and Pressure Vessel Code sections. For this preliminary assessment, the criticality control constraint of $0.95 \mathrm{~K}$-effective is assumed to be met since the same basket design and cask internal dimensions of the BR-100 cask are used here. Preliminary thermal evaluations were not performed; however, except for the potential need to include cooling fins within the neutron shield, the metal cask body should pose no heat dissipation problems.

The physical constraints on the weight of the package are dictated primarily by the crane capacities at the commercial reactor facilities. Not all of the commercial reactors can handle 100ton casks. This constraint results in the need to use smaller casks in conjunction with the large MPC/MPU concepts and/or a dry cask-to-cask transfer system. Data on commercial reactor handling capabilities have been accumulated to determine the percentage of large- versus smallcapacity SNF containers required. Reported data have varied as to the model split (i.e., truck v. rail/barge) capabilities at the existing reactor facilities. The Reactor Data Analysis Program's reactor-specific database broke the cask handling capabilities down as follows:"

- $100 \%$ of all nuclear plants had capabilities to handle 25 -ton casks

- $92.5 \%$ of all nuclear plants had capabilities to handle 40 -ton casks

- $\quad 58.7 \%$ of all nuclear plants had capabilities to handle 100 -ton casks

- $41.3 \%$ of all nuclear plants had capabilities to handle 125 -ton casks

Comparably, the model split used in a MRS conceptual design report was 70 of 121 reactors or $57.8 \%$ could handle rail/barge-sized packages in the 100- to 125-ton range. The most recent transportation model split assumed by TRW Inc. in their MPC evaluation study ${ }^{9}$ was that 102 of the 121 reactors or $84.3 \%$ could ship SNF by rail in large MPC packages. This high utilization of rail casks is feasible only if some form of dry cask-to-cask transfer is performed at the reactors with lower crane capacities. Any of the model splits will require some small casks (e.g., legal weight truck casks of 25 tons) to facilitate transport of all the SNF. However, for this preliminary assessment, only a large rail/barge type of container was evaluated.

\subsubsection{Fabrication Method}

Basically, two fabrication methods could be employed to form the DU shield portion of the SNF container: casting into interlocking rings or segments, and wrought forming into segments or plates. Casting of the DU into interlocking rings or segments is generally considered to be the lowest cost alternative of the two methods. However, close tolerances and complex geometries are not easily obtained with cast materials without extensive machining and milling. Although wrought (or hot rolled) metal in sheets or segments requires more initial treating, machining and milling operations, it can meet higher design specifications if required.

Figures 2 and 3 show the general configuration of a cylindrical vessel fabricated from cast interlocking rings and segments, respectively. Note: essentially the only difference between cast 


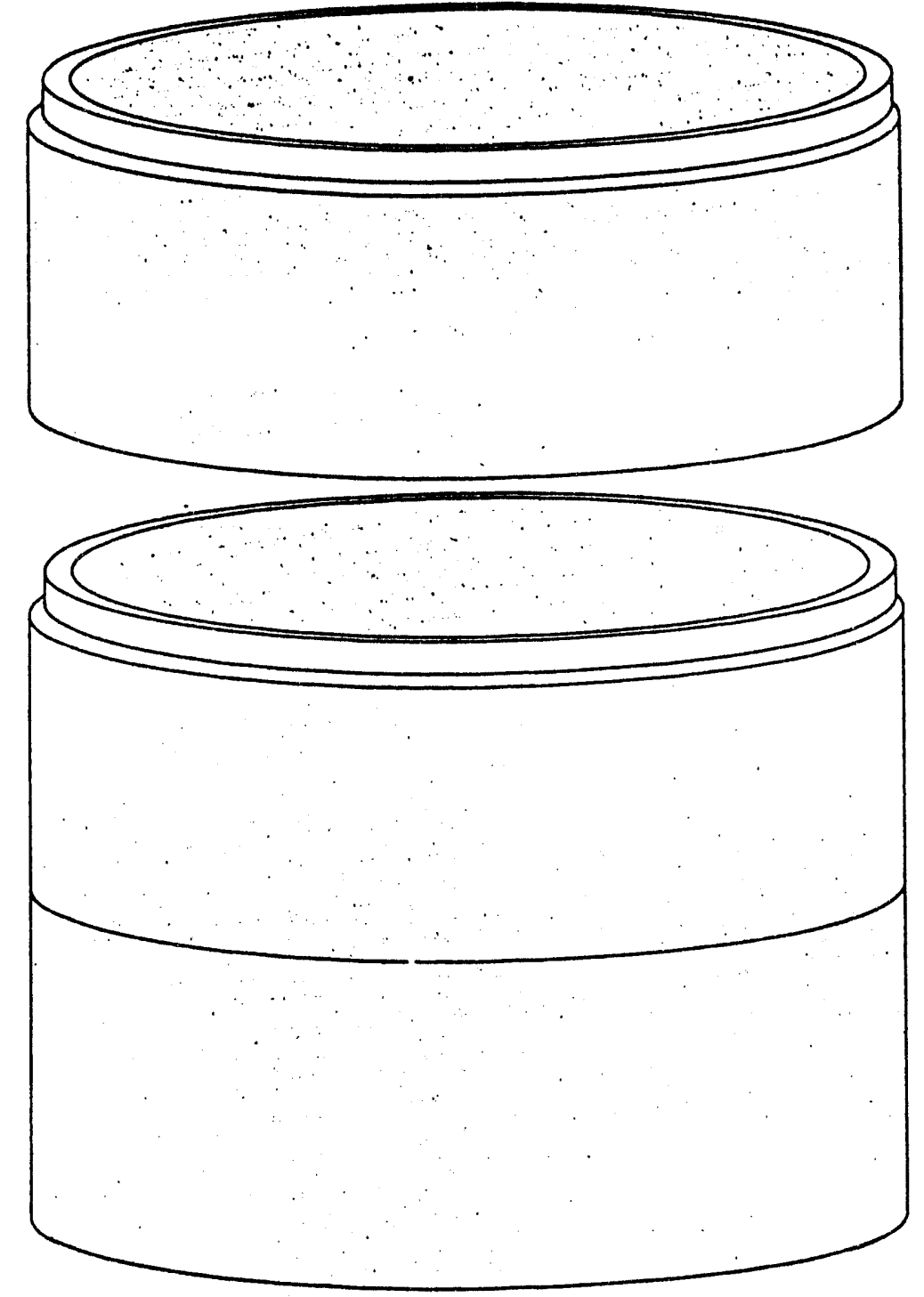

Figure 2. Cast Interlocking Ring Construction 


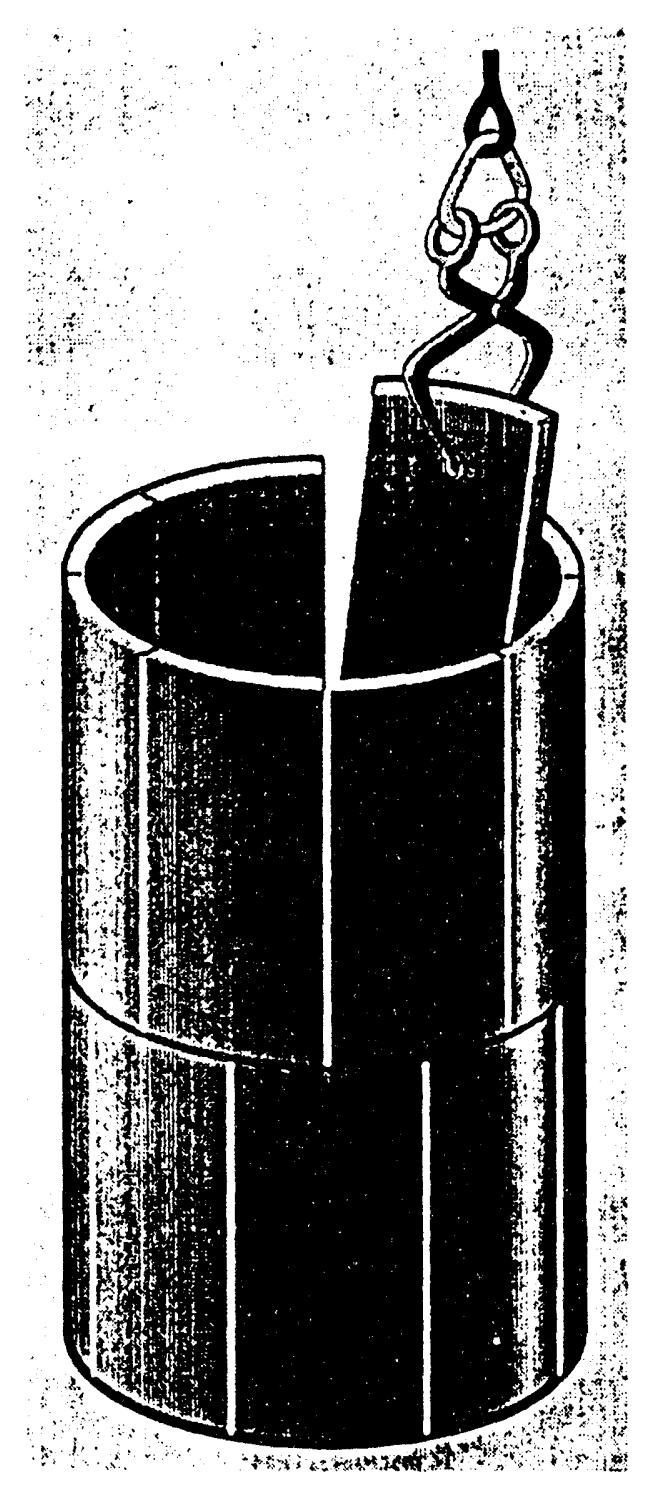

Figure 3. Cast or Wrought Segmented Construction 
and wrought segmented construction is the difference in the process used to produce the segments. The interlocking rings as shown in Figure 2 are generally pinned together to form the cylindrical vessel and require less welding over cast segment fabrication (Figure 3). However, casting is limited for large-diameter rings of the size required for a 21 PWR SNF container. Two companies, Comeco Corporations, Port Hope, Canada, and Aerojet Ordnance Tennessee, Jonesborough, Tennessee, are the only companies identified in North America that can cast largediameter (>40 in.) ring: of DU metal. Comeco Corporation, has the capability to produce large castings of up to 84 in. in diameter with 4- to 5-in.-thick walls. ${ }^{13}$ Aerojet Ordnance, on the other hand, has mold chambers capable of producing castings up to $75 \mathrm{in}$. in diameter and $60 \mathrm{in}$. in length, but their maximum crucible capacity is restricted to $2,720 \mathrm{~kg}$ of melted material. ${ }^{16}$ This restriction in crucible capacity would limit the cast interlocking ring segment height for the container conceptualized here to approximately $11 \mathrm{in.} \mathrm{The} \mathrm{increased} \mathrm{number} \mathrm{of} \mathrm{rings} \mathrm{required}$ to produce a vessel $>181$ in. in length will require more machining and fabrication and is thus far less efficient than fewer rings greater in length. Other potential uranium metal producers and fabricators are limited to smaller diameters of 40 in. or less due to the size of commercially available graphite molds. Containers fabricated using wrought segments are not restricted in this manner. For this assessment, it is assumed that the DU shielded SNF package is fabricated from cast interlocking rings with a minimum of milling and machining expected to be necessary.

Because of the chemical reactivity of uranium with most materials, melting and casting are performed under vacuum in graphite crucibles and molds. The derbies resulting from the Ames reduction process described in Section 4.4 are charged to a melting crucible, together with any alloying agents, and melted in an induction furnace at approximately $2,200^{\circ} \mathrm{F}$. The molten metal is poured into a bank of cylindrical molds and allowed to cool for several hours under a partial vacuum. The cast rings are then machined to fit together to form the cylindrical body of the shield vessel. A cast bottom end-plate would be welded to the cylindrical wall with a full penetration weld to complete the vessel configuration.

\subsubsection{DU Package Designs}

The concept evaluated for this preliminary feasibility study is a $21 \mathrm{PWR} / 52 \mathrm{BWR}$ package similar to the BR-100 transport cask configuration. The internal cavity is $58.5 \mathrm{in}$. in diameter and $181 \mathrm{in.} \mathrm{long.} \mathrm{The} \mathrm{base} \mathrm{of} \mathrm{the} \mathrm{vessel} \mathrm{is} \mathrm{connected} \mathrm{to} \mathrm{the} \mathrm{cylindrical} \mathrm{bodies} \mathrm{of} \mathrm{the} \mathrm{package}$ with full penetration welds. The inner containment barrier is a 0.5 -in.-thick high nickel alloy (i.e., Alloy 825) cylinder with a lid that is weld-sealed closed after SNF loading. Alloy 825 has very good corrosion resistance properties, which are high priority for a repository waste package. The photon shielding portion of the waste package is a 3.5-in.-thick cylindrical vessel made of DU metal immediately surrounding the inner vessel. The outer wall providing the structural component of the package is a 2 -in.-thick cylinder of $304 \mathrm{~L}$ stainless steel. Finally, a 3.75-in. borated polyethylene neutron shield with a 0.25 -in. stainless steel skin surrounds the metal package. The polyethylene neutron shield would be removable, similar to the OCRWM's MPC shipping container overpack as described in Reference 9. The internal fuel basket assembly is assumed to be the same as the BR-100 design, which is made from alloy 6061 aluminum extrusions with T6511 temper. Ceramic-metallic plates, made from $\mathrm{B}_{4} \mathrm{C}$ and aluminum powder, 
are included for criticality control. No assessment of the selection of basket material in the BR-100 report is made as part of this study. Figures 4 and 5 show the longitudinal and radial cross-sections of the package geometry.

\subsubsection{Mass and Weight of Package Components}

Regulatory Guide 7.9 requires that a listing be provided of the weights of individual subassemblies of the SNF package and the total weight of the package contents. This section identifies the subassemblies and the estimated weights. The estimated weights of package components are listed in Table 10 and the total operational package weights are given in Table 11. These component weights are dictated primarily by radiation shielding and preliminary structural analysis. Significantly more design detail and analysis is required to accurately define these parameters. Those identified here are preconceptual only.

Table 10. Weights of the Major Components

\begin{tabular}{lc}
\hline \multicolumn{1}{c}{ Component } & Estimated Weight (lb) \\
\hline Cask body & 126,000 \\
-U metal & 94,700 \\
-Alloy 825 & 5,650 \\
304 L SST & 25,650 \\
Main lid (inc. DU shield plug) & 11,000 \\
Polyethylene Shield & 6,200 \\
Basket assembly & 9,000 \\
Impact limiters & 8,000 \\
Payload of SNF & $2,300,500 \mathrm{BWR})$ \\
Handling equipment & 2,500 \\
Railcar & 45,000 \\
Skid & 11,500 \\
Water & 10,000 \\
& \\
\hline
\end{tabular}

Table 11. Total Estimated Operational Weights

\begin{tabular}{lc} 
Operational Function & Total Weight lb (tons) \\
\hline Crane hook load & $192,000(96)$ \\
Dry storage weight & $185,700(93)$ \\
Gross vehicle weight & $290,000(125)$
\end{tabular}




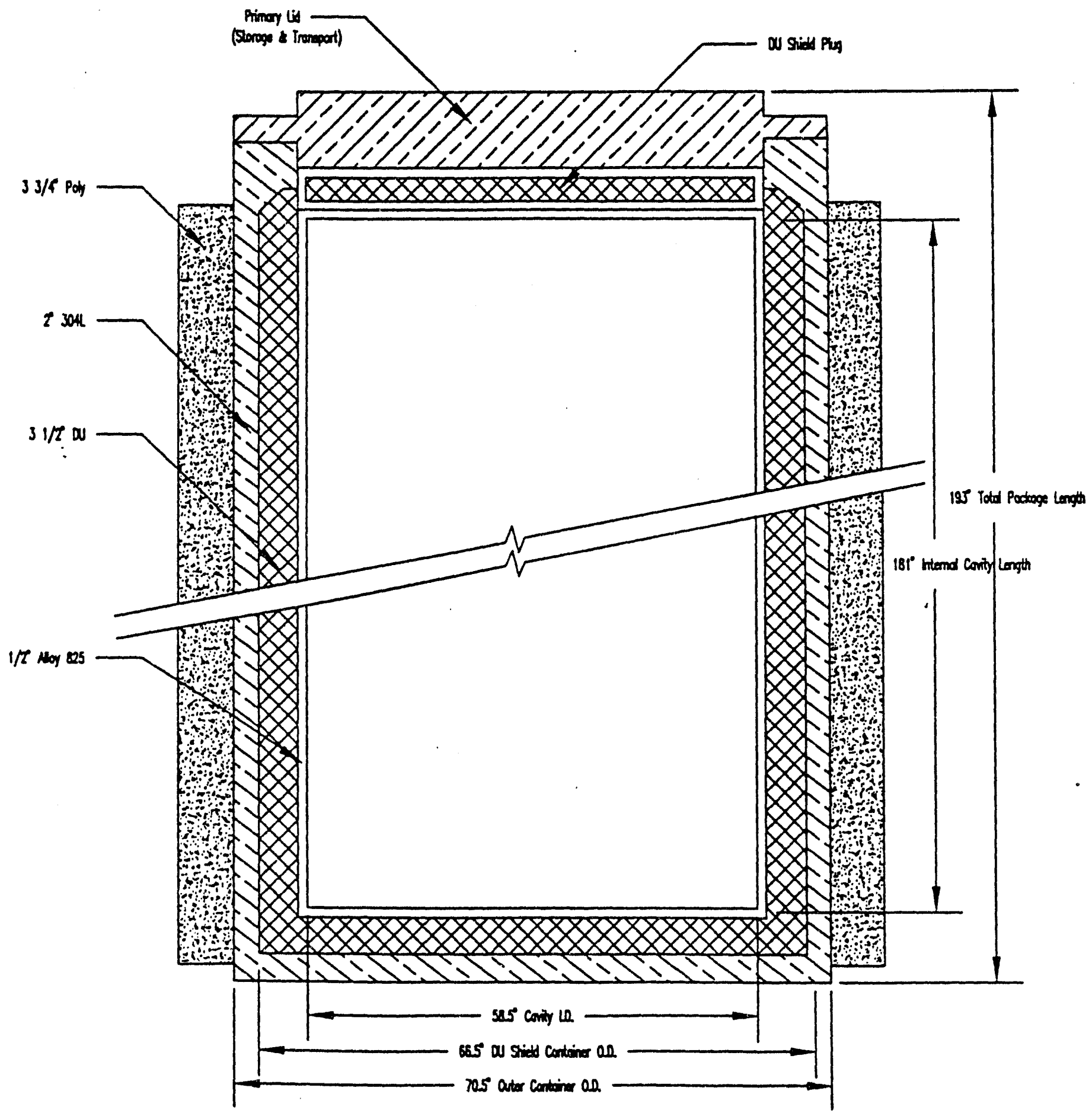

Figure 4. Longitudinal Cross-Section 


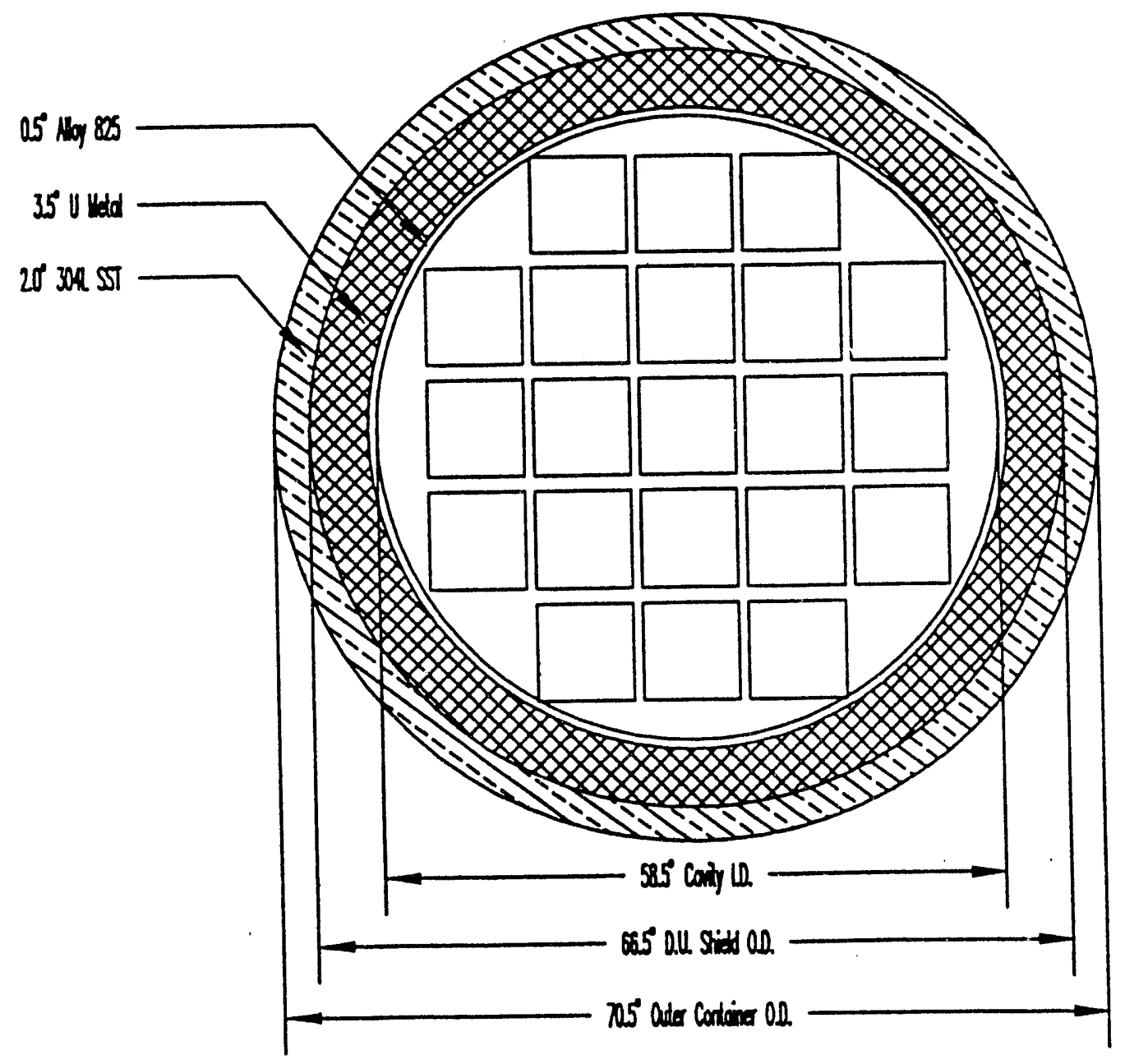

Figure 5. Radial Cross-Section 


\subsubsection{Quantity of Spent Fuel Packages Required}

The basis used for determining the total the number of DU shielded SNF containers to be fabricated is the current plus projected inventory of 294,618 (86,050 MTU) LWR fuel assemblies. The necessary yearly production rate for fabrication of the containers is based on the OCRWM's spent fuel acceptance and emplacement schedule as presented in Reference 8, and shown in Table 12.

Of the 294,618 LWR fuel assemblies, 131,838 are PWRs and 162,780 are BWRs. Assuming that all these assemblies can be loaded and transported in a large rail/barge (21PWR/52BWR) package configuration, the resulting number of containers required is estimated to be 9,500 . This includes approximately a $1 \%$ allowance for broken fuel and out-of-spec fuel reducing the overall effective capacity of the containers. Approximately 6,300 containers for PWR fuel and 3,200 containers for BWR fuel would be needed to handle the inventory as projected. However, as pointed out in Section 4.6.1, not all the reactors can handle large 100-ton SNF casks. Of the 121 reactors, a minimum of 19 would require small (e.g., 25-ton) truck casks to remove and transport their fuel from the reactor pools. It is presently not known what percentage of the overall fuel inventory these 19 reactors contain, and thus, the number of small containers that would be necessary is not estimated here. Instead it is assumed that all the fuel would go into large rail/barge containers. A small legal weight truck container using DU as the radiation shield can be designed and fabricated the same as the one conceptualized here, and therefore is not assumed to present technical problems in facilitating the removal, storage, and transport of the SNF from all reactors under a DU MPC/MPU philosophy.

The production rates calculated and shown in Table 12, along with the planned acceptance and emplacement schedule, assumes that, of the yearly totals accepted, $65 \%$ is PWR fuel and $35 \%$ is BWR fuel. Additionally, based on the design fuel presented in Table 5, a typical PWR assembly contains $0.465 \mathrm{MTU}$ and a typical BWR assembly contains 0.177 MTU. Therefore, the maximum amount of uranium contained in a container loaded with 21 PWRs is 9.77 MTU and 9.20 MTU for the 52 BWR loading. Using the assumed split by weight (i.e., 65/35), the assumed loading per container, and the scheduled quau_city of SNF accepted per year, an estimate was developed for the number of containers fabricated per year. As shown in Table 12, during the initial three year ramp-up period starting in 1998 the number of packages would increase from approximately 53 up to 105 per year.

For the next 8 years (2000-2008) prior to the second ramp-up period, the number of containers per year remains constant at 105 . During the second ramp-up period the number of packages to be produced per year would increase from 105 to a maximum of 325 in the year 2013. The production rate of 325 containers per year then remains constant through 2035, when acceptance rates begin to drastically decline and end in 2045.

At the maximum production rate of 325 containers per year, the quantity of DU as metal that will be used is approximately $14,940 \mathrm{MT} / \mathrm{year}$. This demand for SNF containers dictates the production level at which conversion of the $\mathrm{UF}_{6}$ to $\mathrm{U}$ metal takes place. Additionally, the total quantity of DU metal needed for fabrication of 9500 containers is approximately 437,000 MTU. 
Table 12. Container Production Rates

\begin{tabular}{|c|c|c|c|}
\hline Year & $\begin{array}{c}\text { Spent Fuel Accepted by } \\
\text { DOE from Reactors (MTU) }\end{array}$ & $\begin{array}{l}\text { Spent Fuel Emplaced in } \\
\text { Repository (MTU) }\end{array}$ & $\begin{array}{c}\text { Number of Containers } \\
\text { Required }\end{array}$ \\
\hline 1998 & 400 & 0 & 53 \\
\hline 1999 & 600 & 0 & 74 \\
\hline 2000 & 900 & 0 & 105 \\
\hline 2001 & 900 & 0 & 105 \\
\hline 2002 & 900 & 0 & 105 \\
\hline 2003 & 900 & 0 & 105 \\
\hline 2004 & 900 & 0 & 105 \\
\hline 2005 & 900 & 0 & 105 \\
\hline 2006 & 900 & 0 & 105 \\
\hline 2007 & 900 & 0 & 105 \\
\hline 2008 & 900 & 0 & 105 \\
\hline 2009 & 800 & 0 & 94 \\
\hline 2010 & 1400 & 300 & 158 \\
\hline 2011 & 2000 & 600 & 220 \\
\hline 2012 & 2600 & 1200 & 283 \\
\hline 2013 & 3000 & 2000 & 325 \\
\hline 2014 & 3000 & 3000 & 325 \\
\hline 2015 & 3000 & 3000 & 325 \\
\hline 2016 & 3000 & 3000 & 325 \\
\hline 2017 & 3000 & 3000 & 325 \\
\hline 2018 & 3000 & 3000 & 325 \\
\hline 2019 & 3000 & 3000 & 325 \\
\hline 2020 & 3000 & 3000 & 325 \\
\hline 2021 & 3000 & 3000 & 325 \\
\hline 2022 & 3000 & 3000 & 325 \\
\hline 2023 & 3000 & 3000 & 325 \\
\hline 2024 & 3000 & 3000 & 325 \\
\hline 2025 & 3000 & 3000 & 325 \\
\hline 2026 & 3000 & 3000 & 325 \\
\hline 2027 & 3000 & 3000 & 325 \\
\hline 2028 & 3000 & 3000 & 325 \\
\hline 2029 & 3000 & 3000 & 325 \\
\hline 2030 & 3000 & 3000 & 325 \\
\hline 2031 & 3000 & 3000 & 325 \\
\hline 2032 & 3000 & 3000 & 325 \\
\hline 2033 & 3000 & 3000 & 325 \\
\hline 2034 & 3000 & 3000 & 325 \\
\hline 2035 & 3000 & 3000 & 325 \\
\hline 2036 & 254 & 3000 & 36 \\
\hline 2037 & 193 & 3000 & 30 \\
\hline 2038 & 142 & 3000 & 25 \\
\hline 2039 & 64 & 3000 & 15 \\
\hline 2040 & 126 & 3000 & 23 \\
\hline 2041 & 58 & 637 & 14 \\
\hline 2042 & 0 & 0 & 0 \\
\hline 2043 & 186 & 186 & 28 \\
\hline 2044 & 18 & 18 & 10 \\
\hline 2045 & 109 & 109 & 21 \\
\hline Total & 86,050 & 86,050 & 9,504 \\
\hline
\end{tabular}


This total demand for DU metal exceeds the current DOE-owned inventory of 408,000 MTU of DU. However, as shown in Table 1, the total inventory of government-owned uranium as of March 1993 is 468,083 MTU, of which 428,491 is FF $_{6}$. Therefore it is assumed that an adequate inventory of DU is available to supply the $U$ metal necessary for this DU recycle option.

\subsection{DU SNF Package Preliminary Analyses}

A SNF package most go through four primary design analyses in order to be licensable by the NRC: shielding analysis to ensure the package design reduces the radiation dose rate to acceptable levels, criticality analysis to verify the package contents will not go "critical" under a fully reflected and moderated condition, structural analysis to verify that the package will maintain its integrity to contain the SNF under normal and off-normal loading conditions, and thermal analysis to ensure the rate of heat dissipation is sufficient to maintain a fuel cladding temperature at or below $340^{\circ} \mathrm{C}$ under all normal and off-normal conditions.

For this preliminary assessment, only the shielding analysis was performed in depth using detailed computer codes. The preliminary structural calculation used to determine an outer stainless steel wall thickness was performed using simple elastic beam bending theory under a tip-over accident scenario. No criticality analysis was performed; however, criticality control is typically attained by using boron poison in the fuel basket assembly (e.g., borated aluminum, borated stainless steel, or ceramic-metallic plates) and by using geometry. Since the DU shielded package used in this study is assumed to use the same basket geometry and structure of the BR-100 transportation cask, it is initially assumed that criticality will not be a significant issue. Additionally, no thermal modeling was performed; however, except for the probable need to incorporate heat transfer fins within the polyethylene neutron shield, the metal cask body should allow for sufficient heat transfer. More in-depth analysis of these various design parameters should be performed as the DU recycle program activities continue.

\subsubsection{Shielding Analysis}

A series of preliminary calculations were performed using one- and three-dimensional radiation transport models to determine adequate $U$ metal shield thicknesses for the 21 PWR container. The shielding analysis used the PWR source term from the B\&W BR-100 Preliminary Design Report (Table A1 and A2 in Appendix A) and the radiation transport codes ANISN ${ }^{17}$ and MCNP. ${ }^{18}$ ANISN is a one-dimensional discrete-ordinates-transport code that solves the Boltzmann transport equation for neutrons and/or gamma rays in slab, sphere, or cylindrical geometry. The sources may be fixed, fission, or a combination of the two. Cross sections may be weighted using the space- and energy-dependent flux generated in solving the transport equation. MCNP is a three-dimensional Monte Carlo code. These codes embody different techniques to solve the problem of neutron particle transport, but both can give reliable estimates of the dose rate outside the SNF package. Principally, the ANISN calculations were used for the radial dose rates, with supporting MCNP calculations giving agreement.

The initial modeling was performed to obtain the relative thickness of $U$ metal to stainless steel required to attenuate the photon and neutron sources. The calculations looked at the effect of varying the stainless steel and DU shield thicknesses on the limiting dose rates at the surface 
of the package and at $2 \mathrm{~m}$ from the surface as dictated by transportation regulations [10 CFR 71]. Currently, only the radial dose rates at the mid-height of the container have been modeled. However, preliminary results and BR-100 data showed that the neutron radiation at the longitudinal mid-plane of the container controls the total wall thickness of the package and is therefore the limiting criteria. In modeling, the homogenized fuel (Table A5) was extended over the entire inner cavity radius and length encompassing the total active and nonactive fuel regions rather than the actual fuel cross section and height. This approach simplifies the modeling but leads to a slight conservatism in neutron source strength since the height of the active fuel region is approximately four-fifths that of the internal cavity (i.e., $144 \mathrm{in.}$ v. 181 in). Additional modeling to more accurately define the radiation doses at different points on the package are expected to be performed as the detailed conceptual design of a DU package progresses.

The relative thickness of the stainless steel and $U$ metal determined in the shielding analysis is shown in Figures 6 and 7. Figure 6 shows the thicknesses of DU plus stainless steel required to maintain a neutron dose rate at or below $200 \mathrm{mrem} / \mathrm{hr}$ at the surface of the cask. For example, if $10 \mathrm{~cm}$ of DU is used, an additional $12.3 \mathrm{~cm}$ of stainless steel will be required to meet the $200 \mathrm{mrem} / \mathrm{hr}$ contact dose rate limit. Figure 7 show this same relationship for the $2-\mathrm{m}$ dose rate limit of $10 \mathrm{mrem} / \mathrm{hr}$. Observation of these two graphs clearly shows that the neutron dose rate at $2 \mathrm{~m}$ controls the minimum wall thickness of an all metal package. Extrapolating the linear relationship observed between the end points of the relative wall thicknesses modeled, and shown in Figure 7, it would take approximately $30.75 \mathrm{~cm}$ of DU (i.e., DU metal only) versus $51 \mathrm{~cm}$ of stainless steel to effectively attenuate the neutron radiation emitted from a 21 PWR fuel container. This is a $40 \%$ reduction in wall thickness required for attenuating neutron radiation if DU metal rather than stainless steel was used. Additionally, the graphs clearly show that an all-metal fully shielded SNF package would require excessive wall thicknesses (i.e., $51 \mathrm{~cm}$ ), which in turn would exceed weight limits for handling and transporting functions. These initial calculations led to revising the envisioned SNF package design to use a borated polyethylene barrier for the neutron shield. Figure 8 shows the relative thickness of polyethylene that will be required to attenuate the neutron radiation in addition to the $U$ metal and stainless steel required for photon shielding. Without considering structural requirements, the graph shows that the more restrictive 2-m dose rate (i.e., $10 \mathrm{mrem} / \mathrm{hr})$ limit is met with $1 \mathrm{in}$. $(2.54 \mathrm{~cm})$ of steel $(0.5 \mathrm{in}$. alloy 825 and $0.5 \mathrm{in}$. stainless), $3.5 \mathrm{in} .(8.89 \mathrm{~cm})$ of DU metal and approximately $3.75 \mathrm{in} .(9.5 \mathrm{~cm})$ of polyethylene. However, as detailed below, the structural requirements dictate that the outer stainless steel wall needs to be approximately $2 \mathrm{in}$. thick to carry the loads of a tip-over accident. Therefore, the final package configuration used in this study consists of a 2-in. stainless steel outer wall, 3.5 in. of DU metal, 0.5 in. of alloy 825 , and 3.75 in. of polyethylene.

\subsubsection{Structural Analysis}

The preliminary analysis of the DU package concept evaluated a simple tip-over accident loading condition to determine the stainless steel wall thickness. The structural calculations performed were based on simple elastic beam bending theory, which represents a static design analysis and not dynamic loading conditions. However, a dynarnic amplification factor was added to account for the static analysis approach. The ASME Boiler and Pressure Vessel Code allowable stress factors were used to determine the thickness of the outer stainless steel wall necessary to withstand this type of accident. Table 13 shows the allowable stress limits set forth 


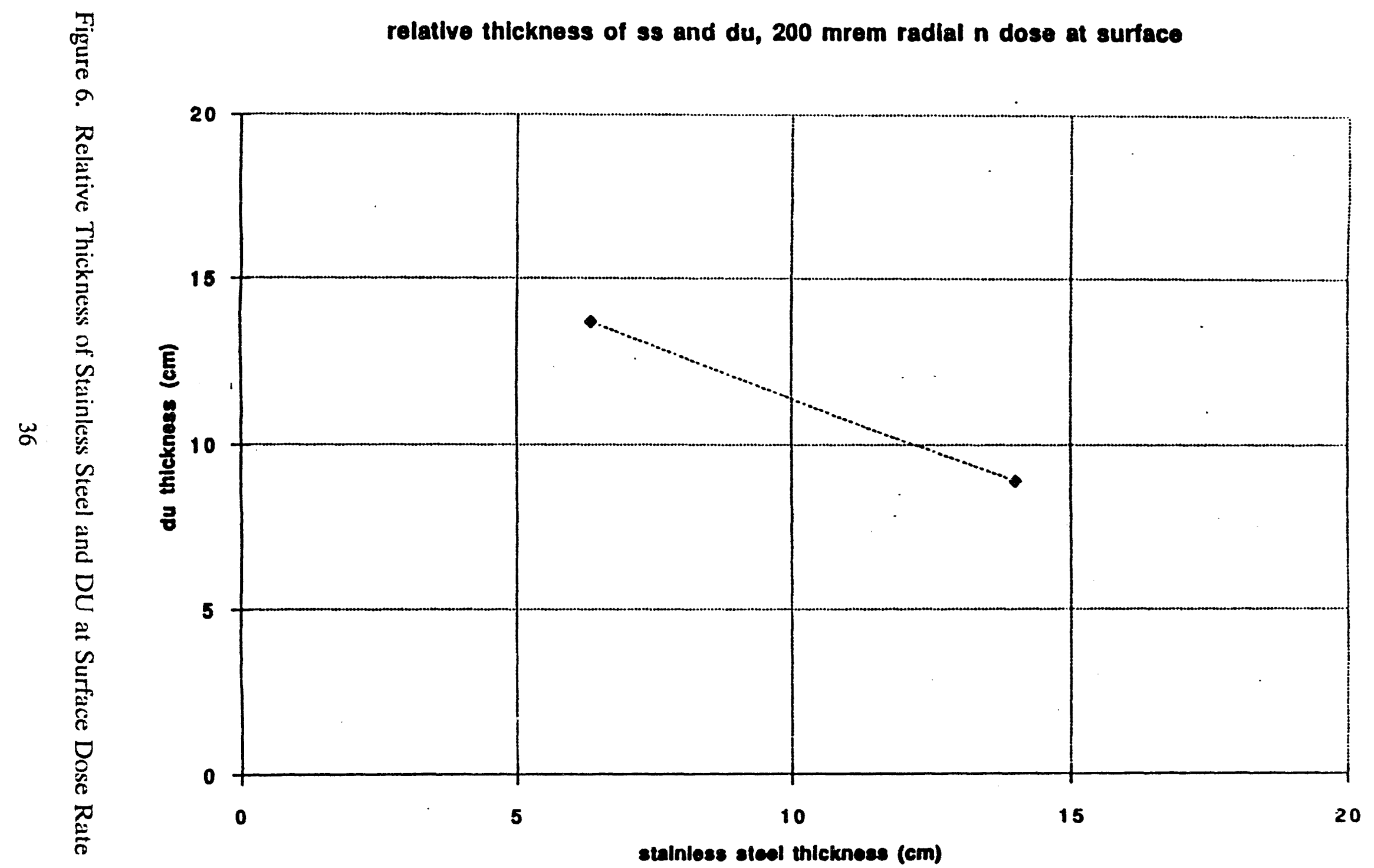




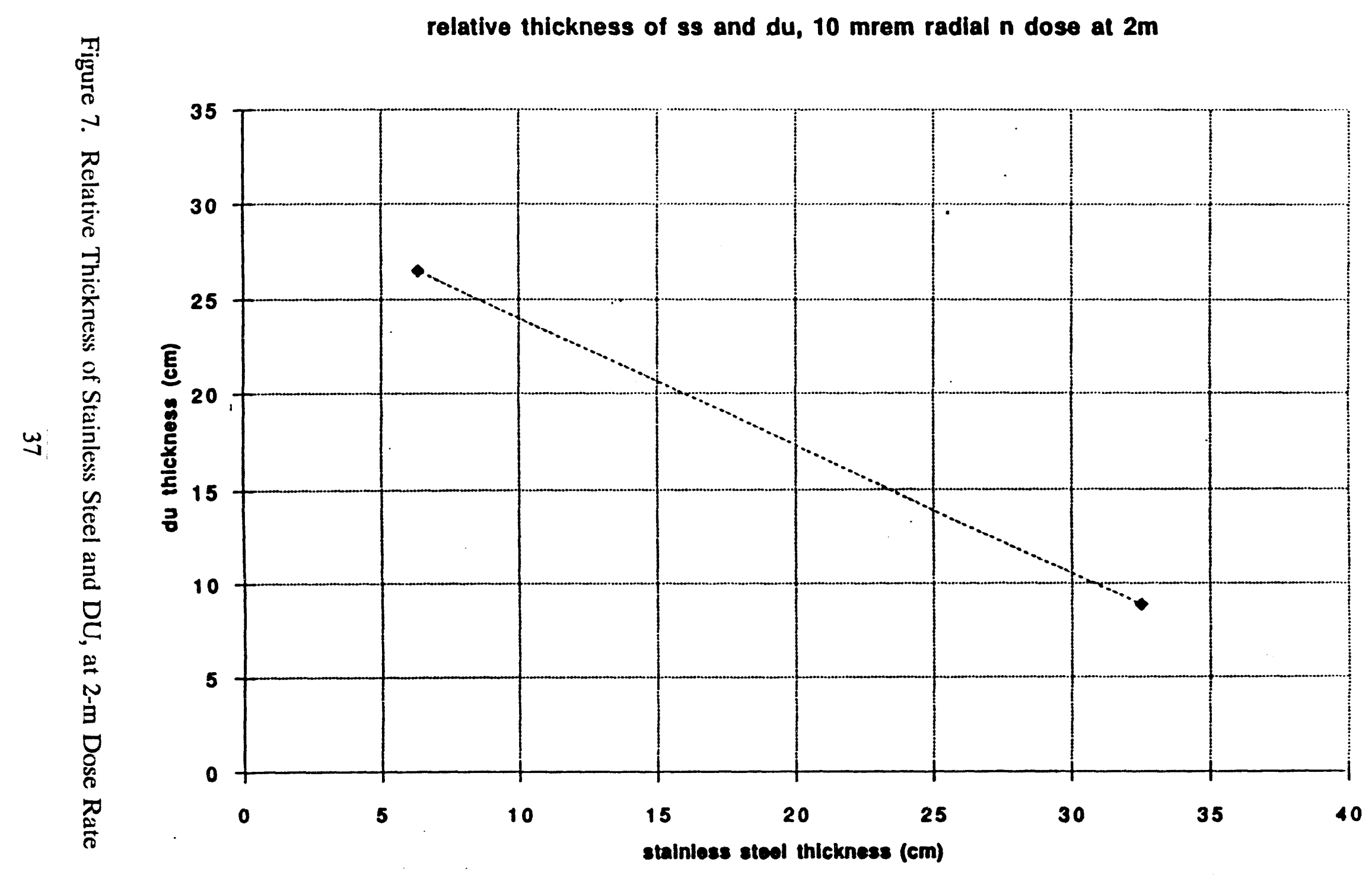


radial dose rate vs $\mathrm{cm}$ poly, $s s=2.54 \mathrm{~cm}, \mathrm{du}=8.89 \mathrm{~cm}$
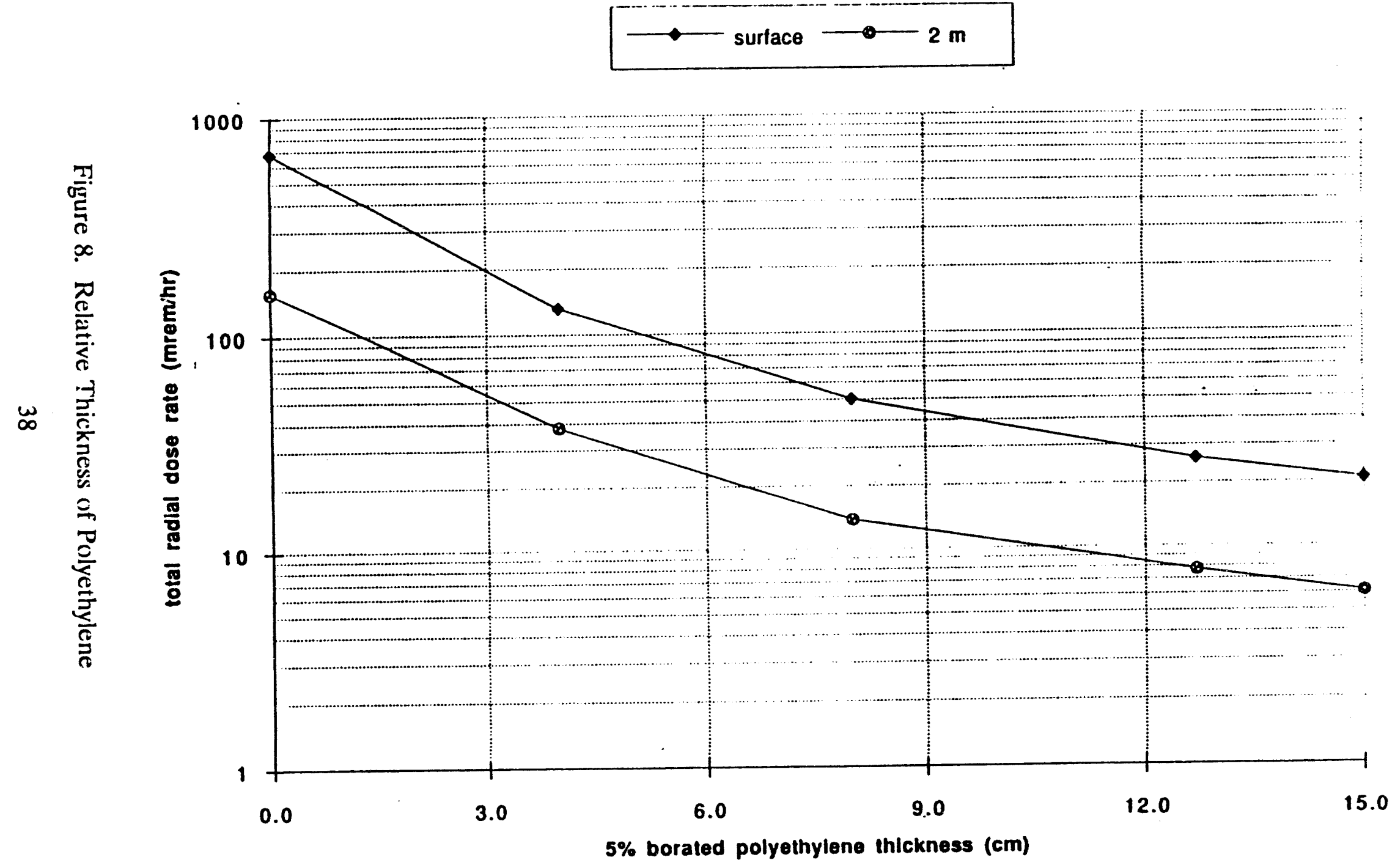
Table 13. Containment Structure Allowable Stress Limits

\begin{tabular}{lcc}
\hline Stress Category & Normal Condition & Accident Condition \\
\hline Primary membrane stress & Sm & lesser of 2.4Sm or 0.7Su \\
$\begin{array}{c}\text { Primary membrane plus } \\
\text { bending stress }\end{array}$ & for cask shell $\alpha \mathrm{Sm}$ & lesser of $\alpha(2.4 \mathrm{Sm})$ or \\
$\mathrm{Sm}=$ & material design stress intensity & \\
$\mathrm{Sy}=$ & material yield strength \\
$\mathrm{Su}=$ & material ultimate strength \\
$\alpha=$ & shape factor $=1.0$ & \\
&
\end{tabular}

in ASME code for containment structures. The allowable stress intensity-Sm-for a 304L stainless steel at a temperature of $400^{\circ} \mathrm{F}$ is 16.7 thousand pounds per square inch [i.e., $16.7 \mathrm{ksi}$ ]. ${ }^{19}$ Based on the ASME Boiler and Pressure Vessel Code, the primary membrane plus bending stress limit is 2.4 times the allowable stress intensity [i.e., $2.4 \mathrm{Sm}$ ] or 0.7 times the ultimate strength [i.e., $0.7 \mathrm{Su}$, whichever is less for accident conditions. The resulting allowable unit stress in the wall of the container is calculated to be $40.08 \mathrm{ksi}$ based on $2.4 \mathrm{Sm}$ and $52.5 \mathrm{ksi}$ for $0.7 \mathrm{Su}$. Therefore, actual unit stress in the wall of the container must be equal to or less than $40.08 \mathrm{ksi}$ to maintain integrity in a tip-over accident.

Based on the mass and dimensional parameters of the various components of the 21 PWR concept as shown in Tables 10 and 11, the maximum actual unit stress on the wall cross section resulting from hypothetical tip-over accident is calculated below. The removable polyethylene shield was not factored into the analysis.

\section{Tip-Over Analysis}

The tip-over analysis of the containers used the following procedure. The maximum potential energy of the container was calculated with it oriented such that the center of gravity was over the corner of the package during tip-over (Figure 9). The potential energy of the container on its side was then calculated and subtracted from the maximum potential energy to determine the energy resulting from impact.

The potential energy resulting from the tip-over is:

$$
\begin{aligned}
& \Delta \mathrm{PE}=\mathrm{W} \Delta \mathrm{H} \text { where: } \quad \Delta \mathrm{PE}=\text { change in potential energy } \\
& \mathrm{W}=\text { the weight of the package } \\
& \Delta H=\text { the change in height of the center of gravity }
\end{aligned}
$$

$\Delta \mathrm{PE}=179,500 \mathrm{lb}(102.75-35.25 \mathrm{in})=1.21 \mathrm{E}+07 \mathrm{in} .-\mathrm{lb}$

This difference in energy was assumed to be absorbed in the crushing of an impact limiter placed on the top of the package during storage. The resultant static force equal to the energy 


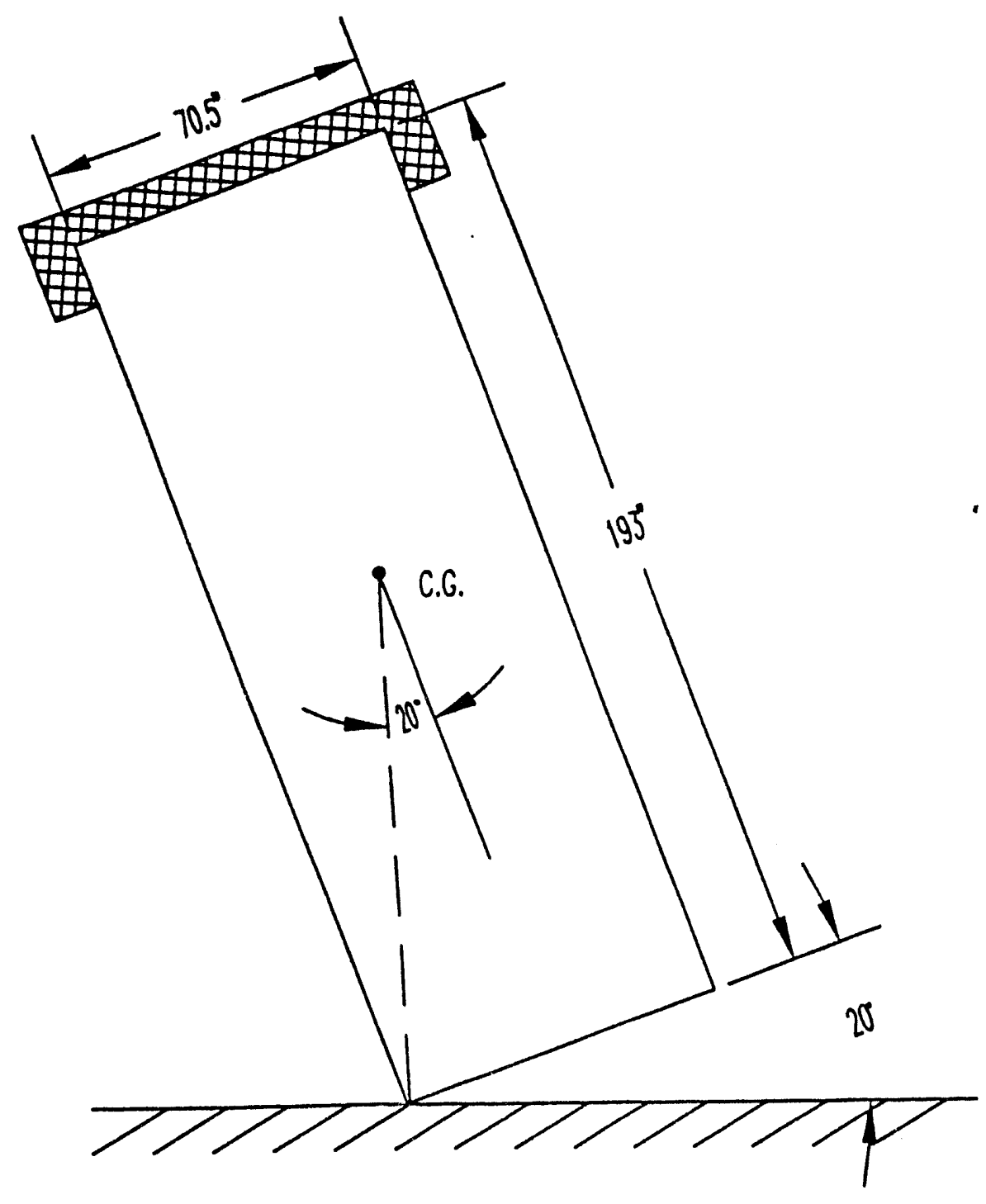

Figure 9. Container Orientation During Tip-Over 
absorbed by the impact limiter was then calculated and applied as a static load acting at the end of the container. A dynamic amplification factor of 2 was applied to the static force to account for dynamic effects of the impact. The actual stress in the wall of the container is then calculated using the beam bending equation:

$$
\begin{aligned}
& \text { Bending Stress- } \sigma=\mathrm{Mc} / \mathrm{I} \text { where: } \begin{array}{l}
M= \\
\mathrm{C}=\text { bending moment } \\
\text { distance from package centerline to outside of } \\
\text { stainless steel wall }
\end{array} \\
& I=\begin{array}{l}
\text { moment of inertia of a cylindrical cross } \\
\text { section }
\end{array}
\end{aligned}
$$

The bending moment results from the static force acting about the center of gravity of the package on its side as shown in the free body diagram in Figure 10. The radial distance from the package centerline to the outside of the stainless steel wall is $35.25 \mathrm{in}$., and the moment of inertia is $2.53 \mathrm{E}+05$ in. $^{4}$ The resulting actual bending stress in the wall of the container is:

$$
\sigma=2.53 \mathrm{E}+08 \mathrm{in}-\mathrm{lb}(35.25 \mathrm{in}) /(2.53 \mathrm{E}+05 \mathrm{in})^{4}=35,260 \mathrm{psi}[35.26 \mathrm{ksi}]
$$

This $35 \mathrm{ksi}$ actual stress is below the $40 \mathrm{ksi}$ allowable stress specified in the ASME Boiler and Pressure Vessel Code.

Conservatively assuming that an internal pressure of $50 \mathrm{psi}$, from fuel rod rupture, is also carried by the outer steel wall rather than the inner alloy 825 wall, the primary plus bending stress of $37.3 \mathrm{ksi}$ is still below the allowable limit of $40.08 \mathrm{ksi}$. Therefore, the 2 -in. stainless steel wall of the package, as conceptualized, would withstand a hypothetical tip-over accident.

\subsection{DU SNF Package Cost Estimates}

The cost estimates presented here are for the major process steps in converting the $\mathrm{UF}_{6}$ to $U$ metal and fabrication of SNF packages. These cost estimates do not parallel life-cycle cost estimates of a SNF package throughout the total spent fuel management system (i.e., from reactor to repository); however, they do provide necessary input data required for a systems life-cycle cost analysis.

\subsubsection{Conversion Costs}

Conversion costs have been reported in several preliminary scoping reports and presentations on work performed to date in support of the DU recycle program. The conversion costs reported by vendors and those estimated or obtained from previous conversion activities within DOE varied from a low of $\$ 8.80 / \mathrm{kgU}$ to a high of $\$ 22.00 / \mathrm{kgU} .^{13,16,20 \mathrm{j}}$ Some of these quotes covered both the conversion operations and the disposal of secondary waste materials (i.e., $\mathrm{MgF}_{2}$ ) in a sanitary landfill. However, as noted in Section 4.4.3, it is assumed for this assessment that the

j. M. Lundberg, Manufacturing Science Corporation, Personal Communication with T. Hertzler, SAIC, June 1993. 


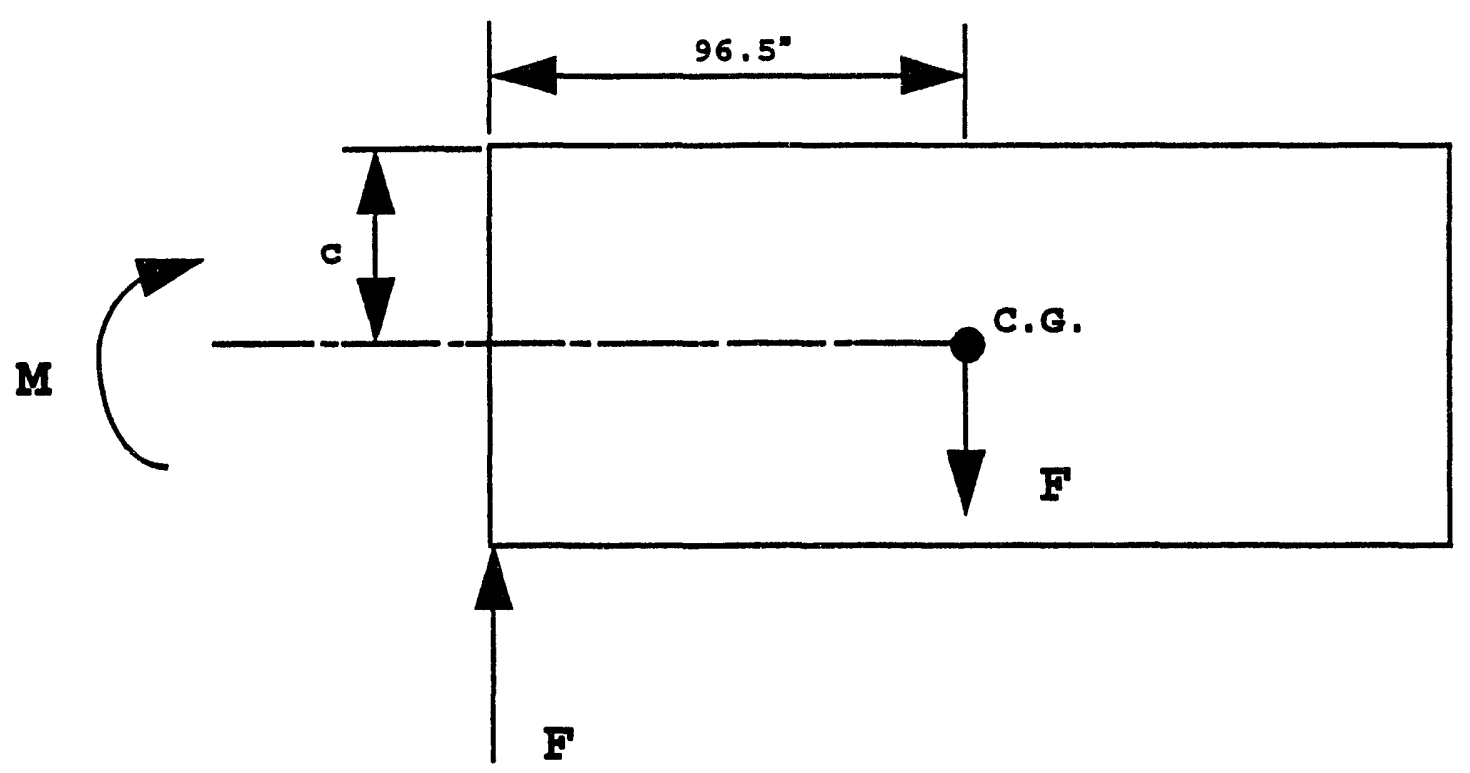

Figure 10. Free Body Diagram Showing Resultant Force and Moment

$\mathrm{MgF}_{2}$ will need to be disposed of in a LLW disposal facility. The higher conversion costs reported were based on uncertainties of specific work requirements, quality of feed materials, and disposal of the by-product and waste forms. To account for the variability in prices quoted and the uncertainties of actual costs in the future, $\$ 10.00 / \mathrm{kgU}$ is assumed to be the cost of converting $\mathrm{UF}_{6}$ to $\mathrm{U}$ metal without $\mathrm{MgF}_{2}$ waste disposal or resale of the anhydrous $\mathrm{HF}$ by-product produced. The $\mathrm{MgF}_{2}$ disposal costs and the $\mathrm{HF}$ resale credits are estimated below and factored into this $\$ 10.00 / \mathrm{kgU}$ unit cost to estimate the net cost for conversion of the $\mathrm{UF}_{6}$ into $\mathrm{U}$ metal. The net cost for conversion is then factored into the cost of fabrication and procurement of individual DU shielded containers in Section 4.8.2. Specific data and assumptions used for $\mathrm{MgF}_{2}$ disposal and $\mathrm{HF}$ resale are as follows: $:^{1,13}$

\section{$\underline{\mathrm{MgF}}_{2}$ Disposal}

- Total disposal costs consist of:

a. Waste package purchase

b. Transportation to a disposal facility

c. Burial operations at the disposal facility

d. Environmental compliance

- Waste packages are considered to be $208-\mathrm{L} 17 \mathrm{C}$ metal drums costing $\$ 50.00$ each

- Transportation to a disposal facility:

a. Is by truck from point of conversion

b. Point of conversion is assumed to be at Piketon, Ohio

c. Cost to transport is $\$ 2800.00$ per truckload

d. Weight limit per truckload is $42,000 \mathrm{lb}(19 \mathrm{MT})$ 
- Burial operations at disposal facility:

a. Disposal is considered to be at the Nevada Test Site (NTS)

b. Burial operation charges are $\$ 10.00 / \mathrm{ft}^{3}$

- Environmental compliance costs are assumed to be $\$ 0.02 / \mathrm{kgU}$

- As-package density of $\mathrm{MgF}_{2}$ is $75 \%$ of theoretical density or $147.0 \mathrm{lb} / \mathrm{ft}^{3}$ $\left(0.0668 \mathrm{MT} / \mathrm{ft}^{3}\right)$

- Total mass of $\mathrm{MgF}_{2}$ to dispose of is $196,500 \mathrm{MT}$

- Total volume of $\mathrm{MgF}_{2}$ to dispose of is $2,941,200 \mathrm{ft}^{3}$

\section{$\underline{\text { HF Resale }}$}

- Resale value of $\mathrm{HF}$ is $\$ 1.43 / \mathrm{kg} \mathrm{HF}$

- No container or shipping charges to Allied Signal Inc. are considered

- Total mass of HF is $63,270 \mathrm{MT}$.

Based on the above assumptions and data, the resulting costs to dispose of the $\mathrm{MgF}_{2}$ in an existing DOE LLW disposal facility (i.e., NTS) by cost item is shown below:

$\begin{array}{ll}\text { Waste Package Costs } & \$ 19,900,000 \\ \text { Transportation Costs } & \$ 30,100,000 \\ \text { Burial Costs } & \$ 29,400,000 \\ \text { Env. Compliance } & \$ 9,000,000 \\ \text { Costs } & \$ 88,400,000(\$ 0.24 / \mathrm{kgU})\end{array}$

Economic credit for the resale of the anhydrous HF is the unit value of HF quoted by Allied Signal (i.e., $\$ 1.43 / \mathrm{kg}$ ) times the total $\mathrm{HF}$ generated (i.e., $63,270,000 \mathrm{~kg}$ ) from the conversion process. This credit is $\$ 90,476,000$ or $\$ 0.24 / \mathrm{kgU}$. Based on the data and assumptions applied here, the resale of the HF essentially pays for the disposal of the secondary waste $\mathrm{MgF}_{2}$. Therefore, the net cost for converting the DU into a reusable form (i.e., $U$ metal) including waste disposal and HF resale, is the actual conversion operation cost of $\$ 10.00 / \mathrm{kgU}$. The total cost to supply $437,000 \mathrm{MTU}$ necessary for fabrication of all $9,500 \mathrm{SNF}$ containers is estimated to be $\$ 4.37$ billion.

\subsubsection{Container Capital Costs}

The cost estimates for the fabrication and procurement of the DU shielded SNF container conceptualized in this study were developed based on vendor quotes and appropriate literature data on materials and manufacturing labor costs, design and licensing costs, and estimated profit 
margins. $^{8,9,16,21 \mathrm{j}, \mathrm{k}, \mathrm{l}, \mathrm{m}}$ Material costs were estimated by calculating the various weights of the package components (Section 4.6.4) and then multiplying by a unit cost factor (e.g., $\$ / \mathrm{lb}, \$ / \mathrm{kg}$, etc.) supplied by vendors or other sources. Some of the material costs included labor in addition to raw materials and consumables in the unit cost factors, while others identified labor separately. The costs assume that all inherent manufacturing labor and capital equipment costs are accomplished; that is, employee skills are adequate without additional training or qualifications, and all casting and manufacturing equipment is in place and capable of handling the required throughput necessary to meet demand for the SNF management schedule as shown in Table 12. The cost estimates reflect the assumption that a large number of these containers will be fabricated such that a steady-state fabrication process can be reached and lower per-package costs can be attained. However, due to the nature of the metals supply/fabrication industry, material and fabrication costs do strongly depend on the quantity ordered, certifications required (e.g., ASME Boiler and Pressure Vessel Code nuclear certification), and specific design parameters of the container to be constructed. Since only preconceptual design parameters have been established in this study and no formal request for cost information was solicited from industry, it was impossible to get exact cost quotes. The data reported here provide a rough-order-of-magnitude of the costs that may be expected.

Vendor cost data obtained to date for casting and fabricating DU metal into the photon shield, a large part of the total package cost, have ranged from a low of $\$ 2.20 / \mathrm{kgU}$ to a high of $\$ 22 / \mathrm{kgU}^{13,16,20 \mathrm{j}}$ This wide variation in costs to fabricate is primarily due to the uncertainties in material and product specifications (i.e., alloying and heat treating requirements), geometry and complexity of shape requiring extensive milling/machining process steps, and materials certification and acceptance requirements. The low end of the range is based on simple geometric shape, as cast, without alloying, whereas the high end reflects significant alloying/heat treating, wrought fabrication and/or complex geometries, and high milling and machining requirements. For the SNF container conceptualized here, it is assumed that minimum alloying and machining will be required to form the cast interlocking rings of the DU shield. Therefore, a cost near the mid-point of those obtained was selected as a representative value for this study. The following specific assumptions and data were used in reaching the estimated costs for conversion, fabrication, and procurement of a DU metal shielded SNF container.

\section{Container Cost Assumptions/Data}

1. Cost of converting the $\mathrm{UF}_{6}$ to $\mathrm{U}$ metal derbies is $\$ 10.00 / \mathrm{kgU}(\$ 4.55 / \mathrm{lb})$.

2. Design and licensing cost estimates for storage-only metal casks have been reported at $\$ 1.5$ million. ${ }^{21}$ This value was amortized over 100 containers to derive a unit cost of $\$ 15,000$ per container.

k. D. White, Reactor Experiments Inc., Personal Communication with T. Hertzler, SAIC, April 4, 1994.

1. N. Seagle, TRW Inc., Personal Communications with T. Hertzler, SAIC, April 1994.

m. T. Hertzler, Depleted Uranium Project Memorandum - Materials and Fabrication Cost Data for DU and Stainless Steel, Predecisional Draft, April 29, 1994. 
3. The fuel basket is assumed to be similar to the BR-100 cask with the following cost estimates:

$$
\text { PWR Fuel Basket }
$$

a. Material costs: ${ }^{8}$

b. Labor costs: ${ }^{8}$
$\$ 100,000$

$\$ 40,000$

$\$ 140,000$
BWR Fuel

Basket

$\$ 150,000$

$\$ 50,000$

$\$ 200,000$

Note: The BWR fuel basket cost was increased over that estimated by TRW to account for an increase in BWR capacity from 48 to 52 .

4. DU metal shield fabrication, which includes labor and materials for remelting derbies, casting to shape, milling and machining interlocking ends, assembly, and testing/inspection is assumed to be $\$ 11.00 / \mathrm{kgU}(\$ 5.00 / \mathrm{lb})$.

5. Cost for materials and fabrication of the stainless steel shell surrounding the DU metal was estimated based on a range of values obtained from vendor quotes and literature sources. ${ }^{8,1, m}$ Unit costs used in this study assume a simple geometry with little milling/machining being required.
a. Material unit costs:
$\$ 2.50 / \mathrm{lb}$
b. Labor unit costs:
$\$ 2.50 / \mathrm{lb}$
$\$ 5.00 / \mathrm{lb}$

6. The Alloy 825 inner containment vessel material unit costs is $\$ 7.50 / \mathrm{b}$, which is assumed to include all materials and labor. ${ }^{8, \mathrm{~m}}$

7. Labor for assembly of all components in to the final vessel is assumed to be twice that estimated for an MPC or approximately $\$ 6,700 .^{8}$

8. Externals such as trunnions, storage impact limiters, etc., are assumed to cost approximately $\$ 50,000$ per container in storage. Since only a limited number of the 9,500 containers will be in storage at any one time, the total cost for externals was calculated based on the projected at-reactor and MRS storage needs and distributed over the total number of containers fabricated.

a. Additional at-reactor and MRS storage requirements: ${ }^{k}$
At-reactor:
2,994 MTU
313 containers
MRS storage:
$15,500 \mathrm{MTU}$
1,622 containers
18,494 MTU
1,935 containers
b. Total cost of external hardware
$\$ 96.75$ million
c. Average cost per container
$\$ 10,200$ 
Note: The total for containers assumes MRS lag and interim storage is at regulatory maximum at the same time at-reactor storage needs are maximum (conservative assumption).

9. The polyethylene neutron shield is assumed to be used on all containers in storage even though shield design attenuates radiation dose rates to 10 CFR 71 transportation limits, which are significantly more restrictive than 10 CFR 72 independent spent fuel storage installation requirements. As with external hardware costs, the neutron shield cost is averaged over total number of containers fabricated. Shield material and fabrication cost is $\$ 4.00 / \mathrm{lb}^{\mathrm{k}}$
a. Cost per container in storage: $\$ 24,800$
b. Total cost for 1,935 containers: $\$ 48.0$ million
c. Average cost per container: $\$ 5,000$

Based on these assumptions/data and the component weights presented in Table 10, the costs to fabricate packagc components and procure a licensed DU shielded container were calculated and are presented in Table 14. Since there is a considerable difference between the fabrication of the fuel baskets of the PWR and BWR fuel types, the costs are listed separately in Table 14. The total cost for fabrication of the estimated 9,500 containers (6,300 PWRs and 3,200 BWRs), as detailed in Section 4.8.3, takes into account these differences in the per-package costs of the PWR and BWR configurations.

\subsubsection{Total Container Cost Summary}

Although the total demand for DU metal (i.e., $\sim 437,000 \mathrm{MTU}$ ) for container fabrication exceeds the current DOE-owned $\mathrm{UF}_{6}$ inventory (i.e., $375,000 \mathrm{MTU}$ ) as indicated in Section 4.6.5, the total cost to convert $437,000 \mathrm{MTU}$ and fabricate the 9,500 containers is presented here. This assumes that the total demand for $437,000 \mathrm{MTU}$ is available from inventories controlled by the U.S. Enrichment Corporation or other government entities. The inventory of DU as of March 1993 is 468,083 MTU, of which 428,491 MTU is UF $_{6}$ (see Table 1). Therefore, sufficient quantities of DU exist to support a large-scale recycling effort should it become a reality.

The total cost for converting $\mathrm{UF}_{6}$ to $\mathrm{U}$ metal and fabricating the $9,500 \mathrm{SNF}$ containers is described below and presented in Table 15. In addition to showing the total cost for conversion and fabrication, for the total system, Table 15 shows the maximum yearly cost of production, the total cost per kilogram of spent fuel contained, and the total cost per fuel assembly contained (with and without DU disposal credits should the DU ever be defined as a waste).

To estimate the total system cost for procurement of the 9,500 containers, with or without disposal credit, the individual container costs for each fuel assembly type were multiplied by the respective number of containers needed (i.e., 6,300 PWR and 3,200 BWR type containers). The other cost parameters (Table 15) were established as follows: 
1. The maximum yearly cost of the containers is based on a maximum of 325 containers per year being fabricated (i.e., 211 PWR and 114 BWR packages) at the peak acceptance rate of 3,000 MTU/year times the cost per PWR and BWR container respectively.

2. The total cost per kilogram of spent fuel contained is estimated by dividing the total system cost by the $86,050,000 \mathrm{kgU}$ of spent fuel requiring disposal.

3. The total cost per fuel assembly is estimated by dividing the total system cost by the projected number of SNF assemblies (i.e., 294,618).

Table 14. Container Cost Estimates

\begin{tabular}{|c|c|c|}
\hline \multirow[b]{2}{*}{ Cost Element } & \multicolumn{2}{|c|}{ Cost per Fuel Assembly Type } \\
\hline & PWR & BWR \\
\hline Conversion & $\$ 459,750$ & $--\mathrm{a}-$ \\
\hline Design and Licensing & $\$ 15,000$ & $-a-$ \\
\hline Fuel Basket & $\$ 140,000$ & $\$ 200,000$ \\
\hline DU Metal Shield & $\$ 505,725$ & $-\mathbf{a - -}$ \\
\hline Stainless Steel Vessel & $\$ 150,950$ & $-\mathrm{a}-$ \\
\hline Alloy 825 Vessel & $\$ 42,375$ & $-\mathrm{a}--$ \\
\hline External Hardware & $\$ 10,200^{b}$ & $-a-$ \\
\hline Polyethylene Shield & $\$ 5,000^{b}$ & $-\mathrm{a}--$ \\
\hline Vessel Assembly & $\$ 6,700$ & $-a--$ \\
\hline Subtotal Cost & $\$ 1,335,700$ & $\$ 1,395,700$ \\
\hline Profit@10\% & $\$ 133,570$ & $\$ 139,570$ \\
\hline Total Cost & $\$ 1,469,270$ & $\$ 1,535,270$ \\
\hline \multicolumn{3}{|l|}{ Total Cost w/ DU LLW } \\
\hline \multicolumn{3}{|l|}{ Total Cost w/ DU RCRA } \\
\hline $\begin{array}{l}\text { a. Costs are the same a } \\
\text { b. External hardware a } \\
\text { of containers fabrica } \\
\text { d. DU LLW disposal c } \\
\text { d. DU RCRA disposal }\end{array}$ & $\begin{array}{l}\text { assembly con } \\
\text { utron shield } \\
121 \mathrm{k}) \text { described } \\
\end{array}$ & the total number \\
\hline
\end{tabular}


Table 15. Total Container Cost Summary

\begin{tabular}{lcccc}
\hline \multicolumn{1}{c}{ Cost Parameter } & $\begin{array}{c}\text { Total } \\
\text { System }\end{array}$ & $\begin{array}{c}\text { Annual } \\
(\text { max. })\end{array}$ & $\begin{array}{c}\text { Total per kgUc } \\
\text { SNF Contained }\end{array}$ & $\begin{array}{c}\text { Total per } \\
\text { SNF Assembly }\end{array}$ \\
\hline $\begin{array}{l}\text { Container Cost w/o DU } \\
\text { disposal credit }\end{array}$ & $\$ 14.2 \mathrm{~B}$ & $\$ 485 \mathrm{M}$ & $\$ 165$ & $\$ 48,100$ \\
$\begin{array}{l}\text { Container Cost w/DU } \\
\text { LLW disposal credit }\end{array}$ & $\$ 8.8 \mathrm{~B}$ & $\$ 302 \mathrm{M}$ & $\$ 102$ & $\$ 29,900$ \\
$\begin{array}{l}\text { Container Cost w/DU } \\
\text { RCRA disposal credit }\end{array}$ & $\$ 3.5 \mathrm{~B}$ & $\$ 121 \mathrm{M}$ & $\$ 41$ & $\$ 11,900$ \\
\hline
\end{tabular}
a. Credit based on average cost for disposal of DU as LLW between NTS and Hanford $(\$ 12.25 / \mathrm{kgU})$
b. Credit based on average cost for disposal of DU as RCRA waste between NTS and Hanford $(\$ 24.38 / \mathrm{kgU})$
c. Cost is per kilogram of uranium metal in a typical SNF assembly

The DU disposal credits taken to offset the cost of manufacturing the container conceptualized in this study are based on disposal costs generated as a part of a previous task and documented in Reference 1. In the referenced report, the cost of disposing of the DU were estimated at two DOE disposal facilities, the NTS and the Hanford Site. The disposal costs included cost for conversion of the $\mathrm{UF}_{6}$ to $\mathrm{U}_{3} \mathrm{O}_{8}$, secondary waste neutralization and disposal, purchase of disposal containers, transportation, handling and burial operations, and environmental compliance. The total disposal costs were estimated for both disposal of the $\mathrm{U}_{3} \mathrm{O}_{8}$ as a LLW and as a RCRA waste. The estimated cost to dispose of the DU as a LLW ranged from $\$ 9.50 / \mathrm{kgU}$ at the NTS to $\$ 15.00 / \mathrm{kgU}$ at Hanford. Additionally, as would be expected, the costs for disposal of the $\mathrm{U}_{3} \mathrm{O}_{8}$ as a RCRA waste increased the costs range substantially to $\$ 18.56 / \mathrm{kgU}$ and $\$ 30.19 / \mathrm{kgU}$ for the NTS and Hanford site respectively.

The value of the disposal credits was calculated by taking the average cost to dispose of the DU, between the NTS and Hanford sites, times the quantity of DU metal utilized in the SNF containers. This disposal credit was then subtracted from the total costs of the containers estimated in Section 4.8.2. The breakdown of average disposal costs and the resulting credits are shown in Table 16. Note that two values are given for the LLW disposal alternative. This is due to the variation in costs reported for the conversion of the $\mathrm{UF}_{6}$ to $\mathrm{U}_{3} \mathrm{O}_{8}$ in reference documents. ${ }^{1,2}$ The values presented in Tables 14 and 15 for container cost with LLW disposal credit are based on the higher of these two disposal values (i.e., $\$ 12.25 / \mathrm{kgU}$ ). A reduction in the cost to convert the DU into an oxide would reduce the amount of credit taken to offset the cost of fabricating a DU shielded container. 
Table 16. DU Disposal Credits

\begin{tabular}{|c|c|c|c|c|}
\hline $\begin{array}{l}\text { Disposal } \\
\text { Type }\end{array}$ & $\begin{array}{l}\text { Disposal Cost } \\
(\$ / \mathrm{kgU})^{\mathrm{a}}\end{array}$ & $\begin{array}{c}\text { Average } \\
\text { Unit Cost }(\$ / \mathrm{kgU})^{\mathrm{b}}\end{array}$ & $\begin{array}{l}\text { Disposal Credit } \\
\text { per Container } \\
(\$ \text { in thousands) } \\
\end{array}$ & $\begin{array}{c}\text { Total Disposal } \\
\text { Credit } \\
(\$ \text { in Billions })^{d}\end{array}$ \\
\hline $\begin{array}{l}\text { LLW } \\
\text { Disposal" }\end{array}$ & $\begin{array}{r}\$ 9.50-\$ 15.00 \\
(\$ 5.30-\$ 10.80)\end{array}$ & $\begin{array}{l}\$ 12.25 \\
(\$ 8.05)\end{array}$ & $\begin{array}{c}\$ 563 \mathrm{k} \\
(\$ 308 \mathrm{k})\end{array}$ & $\begin{array}{l}\$ 5.4 \mathrm{~B} \\
(\$ 2.9 \mathrm{~B})\end{array}$ \\
\hline $\begin{array}{l}\text { RCRA } \\
\text { Disposal }\end{array}$ & $\$ 18.56-\$ 30.19$ & $\$ 24.38$ & $\$ 1,121 \mathrm{k}$ & $\$ 10.7 \mathrm{~B}$ \\
\hline \multicolumn{5}{|c|}{$\begin{array}{l}\text { Disposal cost range between NTS and Hanford }{ }^{1} \text { - cost in parenthesis is based on } \\
\text { reduced conversion costs reported by French of } \$ 4.20 / \mathrm{kgU}^{2} \\
\text { Average cost per kilogram of DU metal utilized } \\
\text { Cost credit applied to individual container cost } \\
\text { Cost credit applied to total system cost }\end{array}$} \\
\hline
\end{tabular}




\section{CONCLUSIONS}

The most important conclusions that can be drawn from this study are as follows:

- Continued storage of the $\mathrm{UF}_{6}$ cylinders through the year 2020 is estimated to range from $\$ 83$ million to $\$ 129$ million based on current practices and necessary/planned new facility construction and increased maintenance and inspection activities.

- The feasibility of a large-scale DU recycle alternative and the cost associated with this alternative depends significantly on the system-wide acceptance of a SNF cask fabricated out of DU metal. Acceptance by nuclear utilities, DOE-OCRWM, and DOE-EM must be unanimous for a large scale recycle program to be implemented.

- The use of DU metal as a nonstructural shielding component in a SNF container is technically feasible. DU metal has been used for shielding in transportation casks and is acceptable by the NRC. The DU package conceptualized here is assumed to be licensable; however, additional design and analyses are required to verify its licensability prospects.

- A large robust (21 PWR) SNF container using $45,975 \mathrm{~kg}$ of DU within the cask can be constructed to meet functional performance specifications for at-reactor storage and transportation handling, radiation shielding, decay heat dissipation, and structural integrity. Approximately 9,500 of these casks would be required to contain the 86,050 MTU of SNF requiring ultimate disposal in a HLW repository.

- The cost of fabricating the DU containers as conceptualized here (i.e., $\$ 1,469,270$ and $\$ 1,535,270$ for PWR and BWR containers, respectively), is not economically justifiable unless emplacement in the repository is acceptable and the costs of DU disposal are avoided.

- The total cost for conversion and fabrication of the 9,500 containers is $\$ 14.2$ billion [\$165/kgU spent fuel contained (SFC)] without DU disposal credit and $\$ 8.8$ billion $(\$ 102.00 / \mathrm{kgU} \mathrm{SFC}$ ) and $\$ 3.5$ billion ( $\$ 41.00 / \mathrm{kgU}$ SFC) with LLW and RCRA disposal credits, respectively.

- The cost credit associated with the alternative of disposing of the DU reserves in a LLW or RCRA waste disposal facility, should disposal become necessary in the future, significantly reduces the cost of conversion and fabrication of a SNF container. 
- Container costs with LLW disposal credit taken (i.e., $\$ 906,000$ and $\$ 972,000$ for PWR and BWR containers) are comparable to cost estimates reported by others for commercial metal transportation, storage, or dual-purpose casks. ${ }^{8, n . o}$

- The cost estimates presented in this report do not parallel the total system life-cycle cost for the entire SNF management program as developed by OCRWM. However, these estimates provide preliminary input data for a total system life-cycle cost analysis.

n. M. Mason, Transnuclear Inc., Personal Communications with T. Hertzler, SAIC, April 1993.

o. T. Danner, Nuclear Assurance Corporation, Personal Communication with T. Hertzler, SAIC, April 1993. 


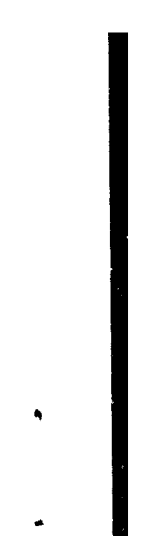




\section{REFERENCES}

1. D.D. Nishimoto and T.J. Hertzler, Depleted Uranium Disposal Options Evaluation, EGG-MS-17297, May 1994.

2. T.R. Lemons, et al., The Ultimate Disposition of Depleted Uranium, K/ETO-44, December 1990.

3. Martin Marietta Energy Systems, Inc., Inventory Status and Requirements for Government-Owned Uranium, Y/ES-009 (Draft), August 1993.

4. Martin Marietta Energy Systems, Inc., Cost Study for the D\&D of the GDPs-Depleted Uranium Management and Conversion, K/D-5940-DF (Draft), September 1991.

5. U.S. Department of Energy-Oak Ridge Field Office, Draft Preliminary Report-UF 6 Cylinder Assessment Team, March 25, 1992.

6. Martin Marietta Energy Systems, Inc., Inventory Analysis Program-Version 6.2, Cylinder Inventory Report, December 1, 1992.

7. M.S. Taylor, V.S. Newman, W.G Halicks, and M.E. Conkel, UF $F_{6}$ Long-Term Storage Cylinder Integrity Management Plan, K/ETO-114, September 1992.

8. R.L. Robertson, CRWMS M\&O, A Preliminary Evaluation of Using Multi-Purpose Canisters Within the Civilian Radioactive Waste Management Systems, A00000000-AA-07-00002, March 24, 1993.

9. TRW Environmental Safety Systems Inc., Volume I-MPC Conceptual Design Summary Report, Rev. 0, September 30, 1993.

10. U.S. Department of Energy, Office of Civilian Radioactive Waste Management, Characteristics of Potential Repository Wastes, DOE/RW-0184-R1, Vol. 2, July 1992.

11. P.L. Hoffman, et al., Comparative Analyses of Spent Nuclear Fuel Transport Model Options, High-Level Waste Management Conference, Vol. 1, Las Vegas, Nevada, April 8-12, 1990, pp. 1043-1050.

12. B\&W Fuel Company, Preliminary Design Report Babcock \& Wilcox BR-100, 100-Ton Rail/Barge Spent Fuel Shipping Cask, DOE/ID/12701--2- Vol. 1, February 1990.

13. F.E. Kosinski, Technics Development Corporation, Review of Commercial Uranium Processing Capability, Draft Report, TDC-100, August 31, 1993.

14. H. Cember, Introduction to Health Physics, Second Edition, Pergamon Press, 1989. 
15. R. Salzbrenner, et al., Sandia National Laboratories, "Structural Credit for Depleted Uranium Used in Transportation Casks," High-Level Waste Management Conference, pp 2241-2248, Las Vegas, Nevada, 1992.

16. R. Yoshimura, Sandia National Laboratories, DU Cask Project Cost Analysis Report on Mine, Draft Report, September 1993.

17. Oak Ridge National Laboratory, ANISN-Multigroup One-Dimensional Discrete Ordinates Transport Code with Anisotropic Scattering, CCC-254, 1979.

18. Los Alamos National Laboratory, MCNP 4A, Monte Carlo N-Particle Code System, 1993.

19. American Society of Mechanical Engineers 1992 Boiler and Pressure Vessel Code, Section II, Materials, Part D, Properties.

20. S. Derrington, Martin Marietta Energy Systems Inc., DOE Capabilities on Depleted Uranium Conversion and Fabrication, Presented at Reuse and Recycle of Depleted Uranium Workshop, October 21, 1993.

21. Electric Power Research Institute (EPRI), Comparative System Economics of Concrete Casks for Spent-Fuel Storage, EPRI TR-102415, June 1993. 


\section{AFPENDIX A}

\section{DESIGN BASIS FUEL RADIOACTIVE SOURCE TERM}




\section{Appendix A-Design Basis Fuel Radioactive Source Term}

The radiological characteristics derive from the presence of radioactive isotopes. Calculations of the isotopes generated in reactors from nuclear fission, activation, or neutron capture is a complex process that is done by using a computer code known as ORIGEN2. ${ }^{a}$ Data output resulting from the use of this code includes:

- quantities of each radionuclide

- $\quad$ radioactivity, both total and by nuclide

- alpha radioactivity, total and by nuclide

- thermal power output, total and by nuclide

- photon energy spectra, total and by nuclide

- neutrons from spontaneous fissions

- neutrons from $(\alpha, n)$ reactions

- quantity of each element

The ORIGEN2 code will generate the radiological characteristics (i.e., source term) for spent nuclear fuel (SNF) depending on parameters such as initial enrichment in the isotope ${ }^{235} U$, irradiation history (i.e., time in the reactor/power output), and decay time after discharge from the reactor. This source term generated from the ORIGEN2 code is directly used in radiation transport codes to determine the shielding requirements for a SNF package necessary to meet regulatory requirements.

The radiation from the fuel assemblies originates from two basic sources, the active fuel region and the upper/lower structural regions. The source term for the fuel region was obtained directly from the B\&W Fuels BR-100 Preliminary Design Report. It consists of both neutron and gamma components from activation products, actinides, and fission products. The source for the structural regions is the gamma radiation from the decay of Co-60. A brief description of the source term from these two regions as developed by B\&W Fuels is provided below.

\section{Fuel Rod Sources}

ORIGEN2 was modeled to calculate the source for the fuel region of a typical pressurized water reactor (PWR) or boiling-water reactor (BWR) fuel assembly. The fuel region spans the active fuel height to include the fuel pellets and cladding material. The PWR model was developed for a Westinghouse $17 \times 17$ PWR on a basis of $1 \mathrm{~kg}$ of initial heavy metal. Thus, the source terms can be applied to PWR assemblies of different vendors merely by correction to the weight of the initial heavy metal. For the BWR fuel assemblies, a model based upon the General Electric (GE) $8 \times 8$ fuel assembly was developed. In both cases, an enrichment of $3.0 \mathrm{wt} \%{ }^{235} \mathrm{U}$ was chosen. The burnup for PWRs and BWRs used in the B\&W analyses were $35 \mathrm{GWD} / \mathrm{MTU}$ and $30 \mathrm{GWD} / \mathrm{MTU}$, respectively. After irradiation, the sources were allowed to decay ten years for the baseline condition. Parametric studies by B\&W Fuels using ORIGEN2 results showed

a. Oak Ridge National Laboratory, A User's Manual for the ORIGEN2 Computer Code, ORNL/TM-7175, July 1980 . 
that the PWR design basis fuel produces the larger source terms and has the lower source density; therefore, it is used as the fuel for the limiting design parameters in the analysis, rather than the BWR source term.

The source terms resulting from the ORIGEN2 modeling were converted into particles per cubic centimeter (cc) per second based on the appropriate mass and volume parameters for the fuel assembly. The PWR gamma source strengths are shown in Table Al and the neutron source strengths are shown in Table A2. BWR gamma source strengths are shown in Table A3 and the neutron source strengths are shown in Table A4. The source term for the fuel region was homogenized (smeared) over the internal volume of the container cavity to represent the ratio of the material density of each individual component of the fuel assembly (e.g., uranium, zirconium, iron, etc.) to the nominal density (see Table A5) of the total material. Source region compositions and characteristics are shown in Table A5.

\section{End-Fitting Region}

Source strengths for the stainless steel end-fitting and inconel 718 end spacer grids and skirts were calculated for Co-59 activation only. The Co-59 activates to Co-60, which emits two gamma rays per disintegration with mean energy of $1.25 \mathrm{MeV}$. This high-energy gamma radiation in the end-fitting region results in higher photon radiation attenuation requirements at the ends of the SNF container. 
Table A1. Photon Sources for PWR Design-Basis Fuel

21 PWR Assemblies with 35,000 MWd/mtU Burnup, 3.0 wt\% Enrichment and 10-yr Cooling

\begin{tabular}{ccc}
\hline Group & Upper Energy, MeV & Total Source, Photons/cc/s \\
\hline 1 & 14 & $2.093-1$ \\
2 & 10 & $1.046-1$ \\
3 & 8 & $1.366+0$ \\
4 & 7 & $1.366+0$ \\
5 & 6 & $1.185+1$ \\
6 & 5 & $1.185+1$ \\
7 & 4 & $1.202+3$ \\
8 & 3 & $1.461+5$ \\
9 & 2 & $6.544+6$ \\
10 & 1.5 & $5.448+8$ \\
11 & 1 & $3.680+8$ \\
12 & 0.8 & $1.840+8$ \\
13 & 0.7 & $2.614+9$ \\
14 & 0.6 & $3.979+9$ \\
15 & 0.4 & $3.564+8$ \\
16 & 0.2 & $5.414+8$ \\
17 & 0.1 & $7.299+8$ \\
18 & 0.06 & $1.417+9$ \\
19 & 0.03 & $7.971+8$ \\
20 & 0.02 & $3.686+9$ \\
TOTAL SOURCE & & $1.522+10$ \\
& & \\
\hline
\end{tabular}


Table A2. Neutron Sources for PWR Design-Basis Fuel

$21 \mathrm{PWR}$ Assemblies with $35,000 \mathrm{MWd} / \mathrm{mtU}$ Bumup, $3.0 \mathrm{wt} \%$ Enrichment and 10-yr Cooling

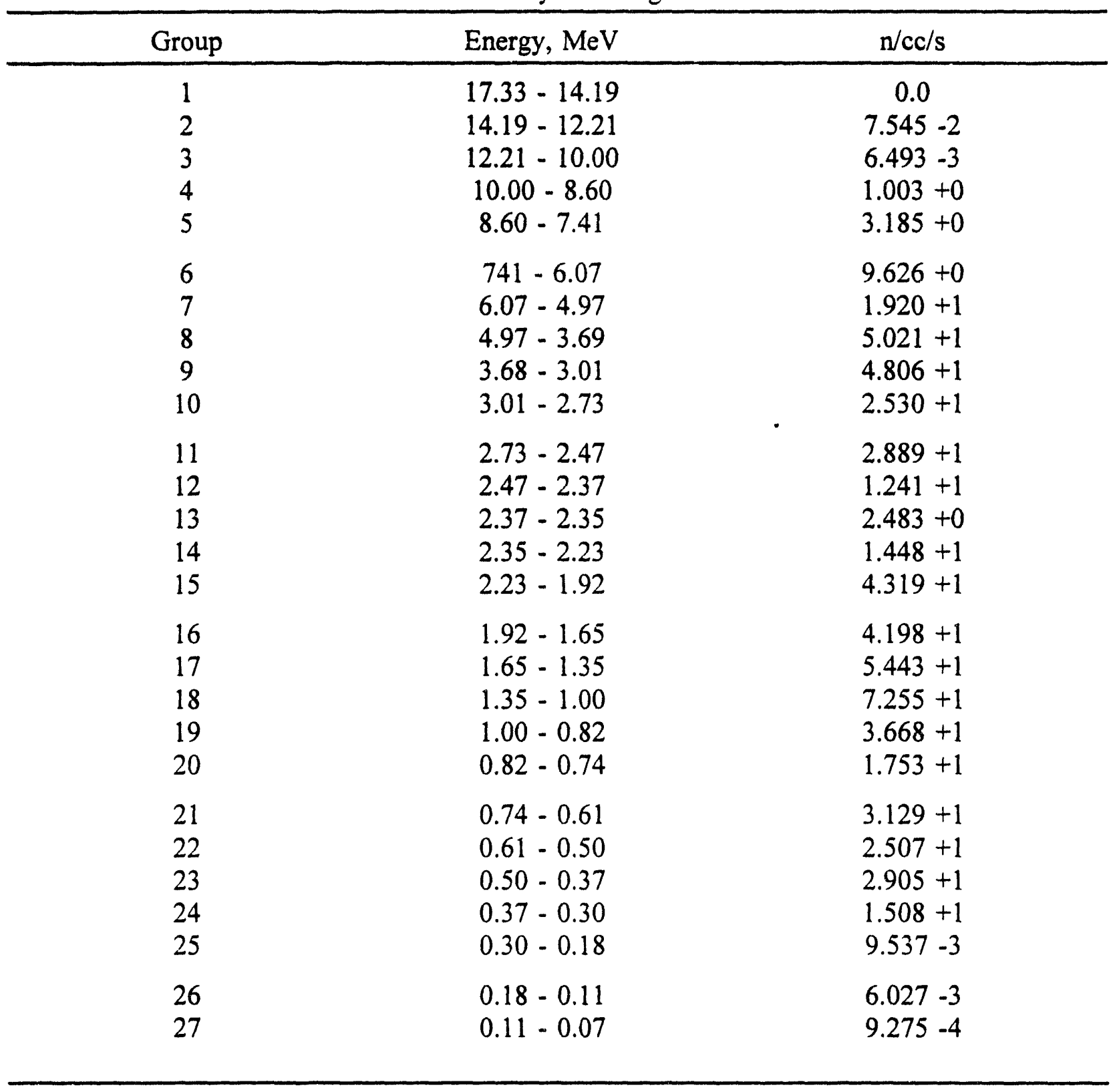


Table A3. Photon Sources for BWR Design-Basis Fuel

52 BWR Assemblies with 30,000 MWd/mtU Burnup, $3.0 \mathrm{wt} \%$ Enrichment and 10-yr Cooling

\begin{tabular}{|c|c|c|}
\hline Group & Upper Energy, $\mathrm{MeV}$ & Total Source, Photons/cc/s \\
\hline 1 & 14 & $1.947-1$ \\
\hline 2 & 10 & $9.739-2$ \\
\hline 3 & 8 & $1.278+0$ \\
\hline 4 & 7 & $1.278+0$ \\
\hline 5 & 6 & $1.103+1$ \\
\hline 6 & 5 & $1.103+1$ \\
\hline 7 & 4 & $9.629+2$ \\
\hline 8 & 3 & $1.133+5$ \\
\hline 9 & 2 & $5.354+6$ \\
\hline 10 & 1.5 & $2.398+8$ \\
\hline 11 & 1 & $3.017+8$ \\
\hline 12 & 0.8 & $1.508+8$ \\
\hline 13 & 0.7 & $2.080+9$ \\
\hline 14 & 0.6 & $3.166+9$ \\
\hline 15 & 0.4 & $2.817+8$ \\
\hline 16 & 0.2 & $4.337+8$ \\
\hline 17 & 0.1 & $5.789+8$ \\
\hline 18 & 0.06 & $1.125+9$ \\
\hline 19 & 0.03 & $6.280+8$ \\
\hline 20 & 0.02 & $2.916+9$ \\
\hline TOTAL SOURCE & & $1.191+10$ \\
\hline
\end{tabular}


Table A4. Neutron Sources for BWR Design-Basis Fuel

52 BWR Assemblies with 35,000 MWd/mtU Burnup, $3.0 \mathrm{wt} \%$ Enrichment and 10-yr Cooling

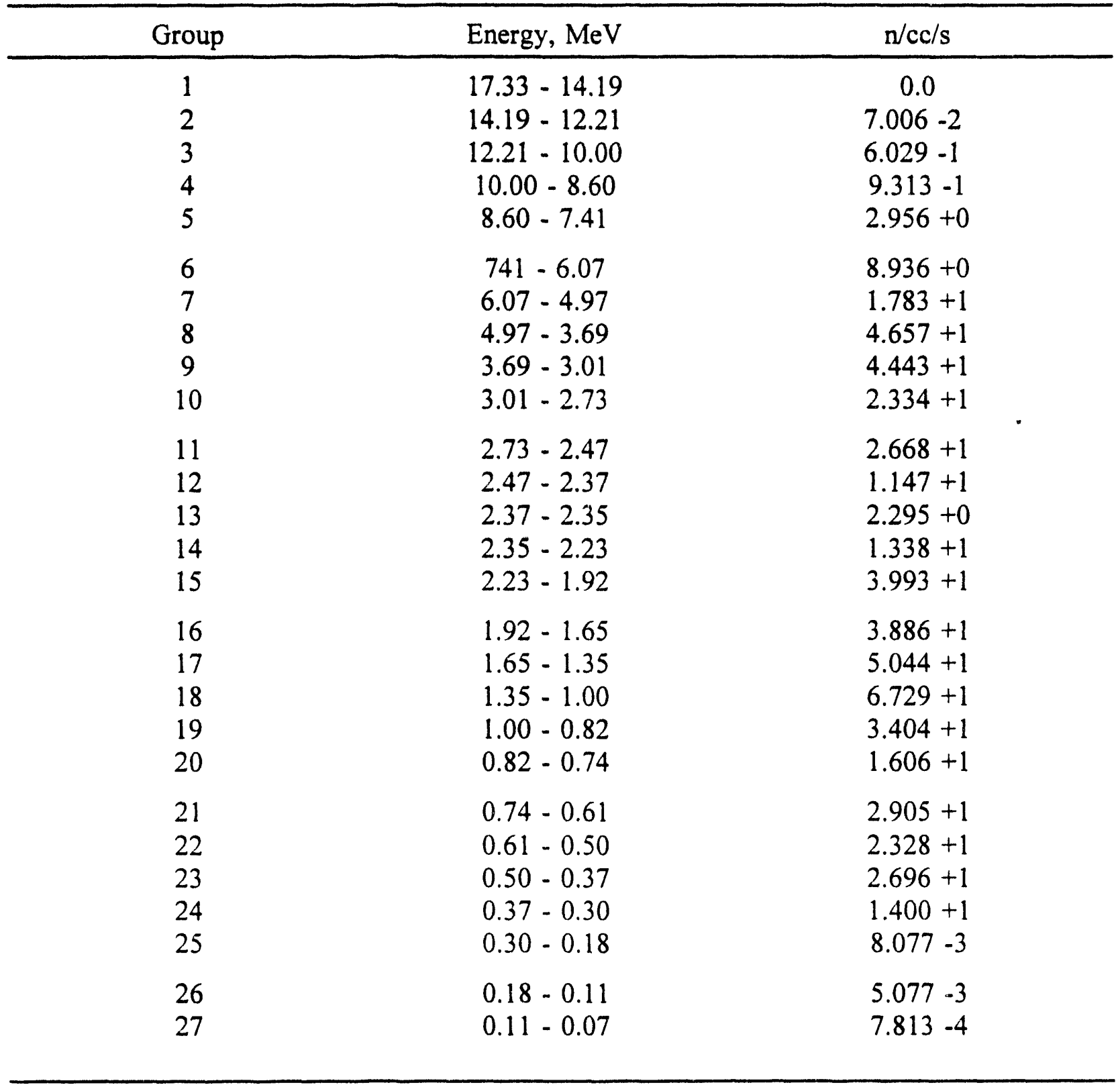


Table A5. Source and Shield Material Compositions

\begin{tabular}{|c|c|c|c|}
\hline & Element & Number Density & $\mathrm{g} / \mathrm{cc}$ \\
\hline $\begin{array}{l}\text { PWR Fuel and Basket Region, } \\
\qquad \rho=2.255 \mathrm{~g} / \mathrm{cc}\end{array}$ & $\begin{array}{c}\text { U-235 } \\
\text { U-238 } \\
\mathrm{O} \\
\mathrm{Zr} \\
\mathrm{Sn} \\
\mathrm{Fe} \\
\mathrm{Al} \\
\mathrm{N} \\
\mathrm{B}-10 \\
\mathrm{~B}-11 \\
\mathrm{C}\end{array}$ & $\begin{array}{lll}1.1109 & -4 \\
3.5466 & -3 \\
7.3169 & -3 \\
2.3203 & -3 \\
2.4771 & -5 \\
1.1323 & -5 \\
5.2954 & -3 \\
1.9157 & -5 \\
2.3427 & -4 \\
9.7058 & -4 \\
0.0131 & -4\end{array}$ & $\begin{array}{c}0.04334 \\
1.4017 \\
0.19438 \\
0.35144 \\
0.00488 \\
0.00105 \\
0.2372 \\
0.00045 \\
0.00080 \\
0.01397 \\
0.00600\end{array}$ \\
\hline $\begin{array}{l}\text { BWR Fuel and Basket Region, } \\
\qquad \rho=2.571 \mathrm{~g} / \mathrm{cc}\end{array}$ & $\begin{array}{c}\text { U-235 } \\
\text { U-238 } \\
\mathrm{O} \\
\mathrm{Zn} \\
\mathrm{Sn} \\
\mathrm{Fe} \\
\mathrm{Al} \\
\mathrm{N} \\
\mathrm{B}-10 \\
\mathrm{~B}-11 \\
\mathrm{C}\end{array}$ & $\begin{array}{lll}1.1071 & -4 \\
3.5342 & -3 \\
7.2896 & -3 \\
2.5006 & -3 \\
2.6697 & -5 \\
9.0972 & -4 \\
1.1254 & -2 \\
2.2840 & -5 \\
2.3427 & -4 \\
9.7058 & -4 \\
3.0131 & -4\end{array}$ & $\begin{array}{c}0.04320 \\
1.39680 \\
0.19511 \\
0.37875 \\
0.00526 \\
0.00084 \\
0.50411 \\
0.00054 \\
0.00080 \\
0.0397 \\
0.00600\end{array}$ \\
\hline $\begin{array}{l}\text { Stainless Steel, } 304 \mathrm{~L} \\
\quad \rho=8.03 \mathrm{~g} / \mathrm{cc}\end{array}$ & $\begin{array}{c}\mathrm{C} \\
\mathrm{Si} \\
\mathrm{Ci} \\
\mathrm{Mn} \\
\mathrm{Fe} \\
\mathrm{Yi}\end{array}$ & $\begin{array}{lll}1.409 & -4 \\
1.720 & -3 \\
1.766 & -2 \\
1.759 & -3 \\
5.842 & -2 \\
8.648 & -3\end{array}$ & $\begin{array}{c}0.00281 \\
0.0802 \\
1.525 \\
0.1605 \\
5.417 \\
0.843\end{array}$ \\
\hline
\end{tabular}




\section{APPENDIX B}

SPENT NUCLEAR FUEL STORAGE AND TRANSPORT REGULATIONS 


\section{Appendix B-Spent Nuclear Fuel Storage and Transport Regulations}

\section{B1. Licensing Requirements for Independent Storage of Spent Nuclear Fuel and High-Level Waste - (10 CFR 72)}

The subparts of 10 CFR 72 of most importance to design of a spent nuclear fuel (SNF) storage container, which is part of an Independent Spent Fuel Storage Installation (ISFSI) or monitored retrievable storage (MRS) system, that will be licensable by the Nuclear Regulatory Commission (NRC) are Subpart B, "License Application Form and Content," Subpart F, "General Design Criteria," and Subpart L, " Approval of Spent Fuel Storage Casks."

Subpart B, § 72.24, "Contents of Application: Technical Information," specifies that each application for a license must include a safety analysis report describing the proposed ISFSI or MRS. The SAR as a minimum must include [italics added]:

1. A description and safety assessment of the site on which the ISFSI or MRS is to be located, with appropriate attention to the design bases for external events. Such assessment must contain an analysis and evaluation of the major structures, systems and components of the ISFSI or MRS ...

2. A description and discussion of the ISFSI or MRS structures with special attention to design and operating characteristics, unusual or novel design features, and principal safety considerations.

3. The design of the ISFSI or MRS in sufficient detail . . including:
a. The design criteria for the ISFSI or MRS pursuant to Subpart $F$ of this part ...;
b. The design bases and the relation of the design bases to the design criteria;
c. Information relative to the materials of construction, general arrangement, dimensions of principal structures . . .; and
d. Applicable codes and standards.

4. An analysis and evaluation of the design and performance of structures, systems and components important to safety ... including determination of:
a. The adequacy of structures, systems, and components provided for the prevention of accidents ...

Subpart F, " General Design Criteria," establishes the design, fabrication, construction, testing, maintenance and performance requirements for structures, systems, and components important to safety in an ISFSI or MRS. Overall requirements are specified in $\S 72.122$ and include such items as:

1. Quality standards

2. Protection against environmental conditions and natural phenomena 
a. Structures, systems, and components ... . must be designed to withstand the effects of natural phenomena such as earthquakes, tornadoes, lightening, hurricanes, floods, tsunami, and seiches without losing their capability to perform safety functions.

3. Confinement barriers and systems

a. The spent fuel cladding must be protected during storage against degradation ...

Subpart L, "Approval of Spent Fuel Storage Casks," outlines the conditions for approval ard the specific requirements for spent fuel storage casks, $\S 72.234$ and $\S 72.236$, respectively. Specific requirements include but are not limited to:

1. Specification must be provided for the spent fuel to be stored in the cask such as, . . . type of spent fuel [i.e., boiling-water reactor (BWR), pressurized water reactor (PWR)], maximum allowable enrichment, . . . burn-up (i.e., megawatt-days/MTU), minimum acceptable cooling time of the spent fuel prior to storage in the cask, maximum heat designed to be dissipated, maximum spent fuel loading, . . .

2. Design bases and design criteria must be provided for structures, systems, and components important to safety.

3. The cask must be designed and fabricated so that the spent fuel is maintained in a subcritical condition... .

4. Radiation shielding and confinement features must be provided sufficient to meet the requirements in $\S \S 72.104$ and 72.106 [annual dose equivalents beyond the control area must not exceed 25 mrem to the whole body, 75 mrem to thyroid, and 25 mrem to any other organ ... under normal operations; 5 rem to the whole body or any organ from a design basis accident]

5. The cask must be designed to provide redundant sealing of confinement system.

6. The cask must be designed to provide adequate heat removal capacity without active cooling systems.

7. The cask must be designed to store the spent fuel safely for a minimum of 20 years and permit maintenance as required.

8. The cask must be compatible with wet or dry spent fuel loading and unloading facilities.

9. The cask must be designed to facilitate decontamination to the extent practicable.

10. The cask must be inspected to ascertain that there are no cracks, pinholes, uncontrolled voids, or other defects that could significantly reduce its confinement effectiveness. 
11. The cask must be conspicuously and durably marked ...

12. The cask and its systems ... must be evaluated, by appropriate tests or by other means acceptable to the commission...

13. To the extent practicable in the design of storage casks, consideration should be given to compatibility with removal from reactor ...., transportation, and ultimate disposition by the Department of Energy.

Numerous regulatory guidelines exist that provide more detail and guidance for meeting the statutory requirements described above. These regulatory guides, along with accepted codes and standards are listed in B3, "Regulatory Documents List;" two important guides are briefly described here.

Regulatory Guide 3.61, "Standard Format and Content for a Safety Analysis Report for a Spent Fuel Dry Storage Cask" provides guidance on the format and content of a topical safety analysis report. The technical SAR, although not specifically required to be submitted as a part of the application process, provides technical detail on the design and evaluation of a SNF cask for dry storage, which can be referenced in the SAR specified in $\S 72.24$. The practice of developing a technical SAR in conjunction with a SAR is generally accepted by the NRC and leads to reduced time, effort, and cost of the licensing process. The technical SAR typically encompasses:

- General description of storage cask

- Principal design criteria to be followed including design criteria for environmental conditions and natural phenomena, safety protection systems, etc.

- Structural evaluation including design, weights and centers of gravity, mechanical properties of materials, general standards for casks, etc.

- Thermal evaluation including thermal properties of materials, specifications of components, thermal evaluation for normal conditions, etc.

- Shielding evaluation including source and model specification, shielding evaluation results, etc.

- Criticality evaluation including spent fuel loading, model specification, criticality calculations, etc.

- Confinement including confinement boundary, requirements for normal and hypothetical accident conditions, etc.

- Operating procedures

- Acceptance criteria and maintenance program

- Radiation protection

- Accident analyses

- Operating controls and limits

- Quality insurance

Regulatory Guide 3.60, "Design of an Independent Spent Fuel Storage Installation (Dry Storage)," provides the NRC's regulatory position on using the ANSI/ANS-57.9-1984, "Design Criteria for an ISFSI dry storage type system." The ANSI/ANS-57.9 design criteria is acceptable 
to the NRC and provides detailed guidance to the designer of a dry storage type ISFSI to specify the minimum design requirements necessary for such an installation.

\section{B2. Packaging and Transport of Radioactive Materials - (10 CFR 71)}

The subparts of 10 CFR 71 specifying design requirements for a SNF transportation container are Subpart D, "Application for Package Approval," Subpart E, "Package Approval Standards," and Subpart F, " Package and Special Form Tests."

Subpart D, $\S 71.31$, "Contents of Application," specifies:

1. An application for an approval under this part must include, for each proposed package design, the following information:

a. A package description as required by $\S 71.33$ including:

1) Classification as Type $B(U)$, Type $B(M)$, or fissile material packaging;

2) Gross Weight;

3) Model Number

4) Identification of the containment system;

5) Specific materials of construction, weights, dimensions, and fabrication methods ... .

b. A package evaluation as required by $\S 71.35$, which specifies that the application must include a demonstration that the package satisfies the standards specified in Subparts $E$ and $F$.

Subpart E, "Package Approval Standards" applicable to a Type B(U) package (i.e., SNF package) encompass:

\section{Confinement Design}

The containment system shall meet the requirements of 10 CFR $\$ \S 71.41$ through 71.57 , which include specific standards for lifting and tie-down, external radiation, fissile materials packages (i.e., criticality standards), and demonstration of compliance with normal and accident conditions of transport.

\section{Shielding Design}

The shielding shall be designed to comply with the external radiation limits of 10 CFR $\S 71.47, \S 71.51$ (a)(2), and 49 CFR $\S 173.441$. The specific radiation limits detailed in 10 CFR $\S 71.47$ for an external container dose rates under normal conditions shall not exceed $200 \mathrm{mrem} / \mathrm{hr}$ on the surface and $10 \mathrm{mrem} / \mathrm{hr}$ at $2 \mathrm{~m}$ from the surface, gamma plus neutron.

\section{Criticality Design}


The SNF container shall be designed to be a Fissile Class 1 per 10 CFR $\S 71.57$. Additionally, the container shall comply with general requirements for fissile packages in 10 CFR $§ 71.55$.

\section{Heat Dissipation Design Parameters}

The package and its contents shall be designed and limited at the time of shipment such that the external surface temperature does not exceed the limits in 10 CFR \& $71.43(\mathrm{~g})$.

Subpart F, "Package and Special Form Tests" encompasses the tests necessary for "normal conditions of transport" [\$ 71.71] and "hypothetical accident conditions" [\$ 71.73]. The conditions and tests specified for normal conditions of transport include:

\section{Normal Conditions:}

1. Heat - An ambient temperature of $38^{\circ} \mathrm{C}$ in still air, and insolation according to prescribed table values.

2. Cold - An ambient temperature of $-40^{\circ} \mathrm{C}$ in still air and shade

3. Reduced external pressure - An external pressure of 24.5 kilopascal absolute.

4. Increased external pressure - An external pressure of 140 kilopascal absolute.

5. Vibration - Vibration normally incident to transportation.

6. Water spray - A water spray that simulates exposure to rainfall of approximately five $\mathrm{cm}$ per hour for at least one hour.

7. Free drop - Between $1 \frac{1}{2}$ and $2 \frac{1}{2}$ hours after the conclusion of the water spray test, a free drop through $0.3 \mathrm{~m}$ [packages over $15,000 \mathrm{~kg}$ ] onto a flat, unyielding, horizontal surface, in a position for which maximum damage is expected.

8. Corner drop - A free drop onto each corner of the package in succession, or in the case of a cylindrical package onto each quarter of each rim, from a height of $0.3 \mathrm{~m}$ onto a flat essentially unyielding surface.

9. Penetration - Impact of the hemispherical end of a vertical steel cylinder of $3.2 \mathrm{~cm}$ diameter and $6 \mathrm{~kg}$ mass, dropped from a height of $1 \mathrm{~m}$ onto the exposed surface of the package that is expected to be most vulnerable to puncture.

\section{Hypothetical Accident Conditions:}

1. Free drop - A free drop of the specimen through a distance of nine $m$ onto a flat, unyielding surface.

2. Puncture - A free drop of the specimen through a distance of one $m$ onto the upper end of a solid, vertical, cylindrical, mild steel bar $15 \mathrm{~cm}$ in diameter.

3. Thermal - Exposure of the whole specimen for not less than 30 minutes to a heat flux not less than that of a radiation environment of $800^{\circ} \mathrm{C} \ldots$

4. Immersion-fissile material - For fissile material, in the case where water inleakage has not been assumed for criticality analysis, the specimen must be immersed under a head of water of at least $0.9 \mathrm{~m}$ for 8 hours. 
5. Immersion-all packages - A separate, undamaged specimen must be subjected to water pressure equivalent to immersion under a head of water of at least $15 \mathrm{~m}$ for a period of 8 hours minimum.

A more inclusive discussion of the storage and transportation design requirements and their specific application in design of a depleted uranium (DU) shielded SNF container will be provided during FY-94 activities. For the purpose of this preliminary feasibility assessment, the shielding requirements of 10 CFR $\S 71.47$ were assessed in some depth (Section 4.7.1) along with a simplified assessment of the structural integrity of the package to withstand a tip-over accident condition (Section 4.7.2).

\section{B3. Regulatory Documents List}

The following regulatory documents are incorporated into this appendix as a resource for future design activities as they are applicable:

\section{B3.1 Title 10 Code of Federal Regulations (NRC):}

1. 10 CFR Part 20, "Standards for Protection Against Radiation."

2. 10 CFR Part 21, "Reporting of Defects and Noncompliance."

3. 10 CFR Part 50, "Domestic Licensing of Production and Utilization Facilities."

4. 10 CFR Part 71, "Packaging and Transportation of Radioactive Material."

5. 10 CFR Part 72, "Licensing Requirements for the Independent Storage of Spent Nuclear Fuel and High-Level Radioactive Waste."

6. 10 CFR Part 73, "Physical Protection of Plants and Materials."

\section{B3.2 Title 49 Code of Federal Regulations (DOT)}

\section{B3.3 Regulatory Guides:}

Division 3:

1. RG 3.48, "Standard Format and Content for the Safety Analysis Report for an Independent Spent Fuel Storage Installation or Monitored Kitrievable Storage Installation (Dry Storage)," Revision 1, 8/89.

2. RG 3.50, "Standard Format and Content for a License Application to Store Spent Fuel and High-Level Radioactive Waste," Revision 1, 9/89.

3. RG 3.53, "Applicability of Existing Regulatory Guides to the Design and Operation of an Independent Fuel Storage installation," Revision 1, 11/86.

4. RG 3.54, "Spent Fuel Heat Generation in an Independent Spent Fuel Storage Installation," 9/84.

5. RG 3.60, "Design of an Independent Spent Fuel Storage Installation (Dry Storage)," $3 / 87$.

6. RG 3.61, "Standard Format and Content for a Topical Safety Analysis Report for a Spent Fuel Dry Storage Cask," 2/89. 
7. RG 3.62, "Standard Format and Content for the Safety Analysis Report for On-site Storage of Spent Fuel Storage Casks," 2/89.

Division 7:

1. RG 7.4, "Leakage Tests on Packages for Shipment of Radioactive Materials," 6/75.

2. RG 7.6, "Design Criteria for the Structural Analysis of Shipping Cask Containment Vessels," Revision 1, 3/78.

3. RG 7.8, "Load Combinations for the Structural Analysis of Shipping Casks for Radioactive Material," Revision 1, 3/89.

4. RG 7.9, "Standard Format and Content of Part 71 Applications for Approval of Packaging of Type B, Large Quantity, and Fissile Radioactive Material," Revision 1, $1 / 80$.

5. RG 7.1 0, "Establishing Quality Assurance Programs for Packaging Used in the Transport of Radioactive Material," Revision 1, 6/86.

6. RG 7.1, "Fracture Toughness Criteria of Base Material for Ferritic Steel Shipping Cask Containment Vessels with a Maximum Wall Thickness of 4 Inches $(0.1 \mathrm{~m}), "$ Revision 0, 6/91.

7. RG 7.12, "Fracture Toughness Criteria of Base Material for Ferritic Steel Shipping Cask Containment Vessels with a Wall Thickness Greater than 4 Inches $(0.1 \mathrm{~m})$ But Not Exceeding 12 Inches $(0.3 \mathrm{~m}), "$ Revision 0, 6/91.

\section{B3.4 NUREG Documents:}

1. NUREG-0612, Control of Heavy Loads at Nuclear Power Plants, 7/80.

2. NUREG/CR-1 815, Recommendations for Protecting Against Failure by Brittle Fracture in Ferritic Steel Shipping Containers Up To Four Inches Thick, 8/81.

3. NUREG/CR-3019, Recommended Welding Criteria for Use in the Fabrication of Shipping Containers for Radioactive Materials, 3/84.

4. NUREG/CR-3826, Recommendations for Protecting Against Failure by Brittle Fracture in Ferritic Steel Shipping Containers Greater than Four Inches Thick, 7/84.

5. NUREG/CR-3854, Fabrication Criteria for Shipping Containers, 3/85.

\section{B3.5 Codes and Standards}

\section{B3.5.1 ASME Boiler and Pressure Vessel Code [I 983 Edition and Addenda through Winter 1985 Addendum]}

1. Section 11, "Material Specifications"

2. Section 111, "Rules for the Construction of Nuclear Power Plant Components," Division 1

3. Section V, "Nondestructive Testing"

4. Section IX, "Qualification Standard for Welding and Brazing Procedures, Welders, Brazers, and Welding and Brazing Operators" 

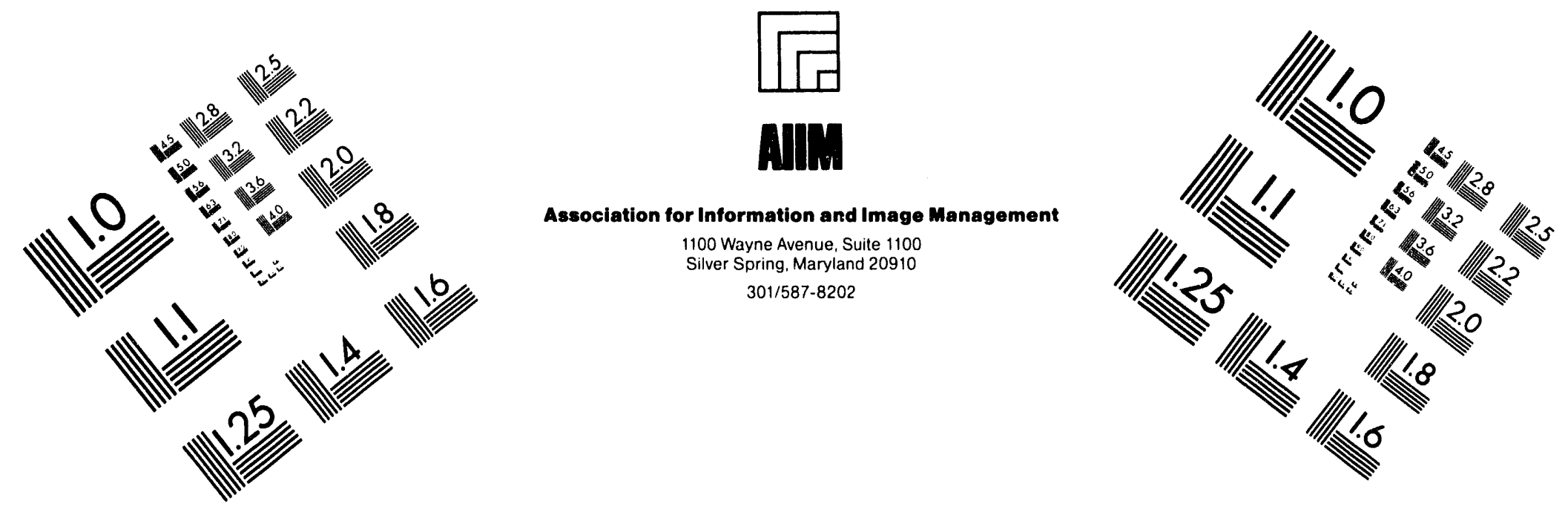

\section{Centimeter}

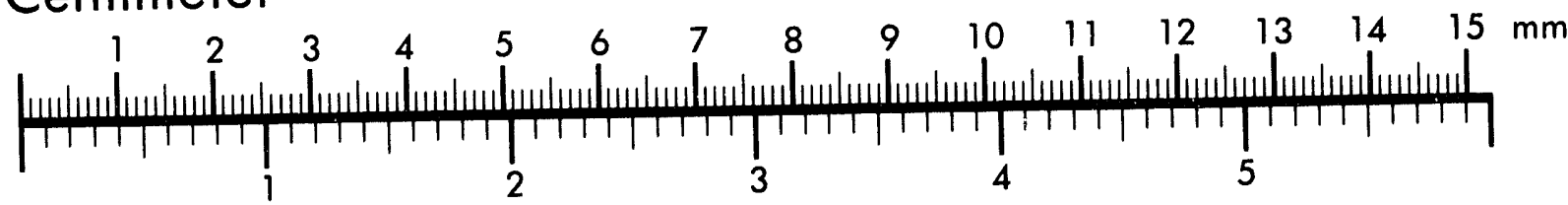
Inches
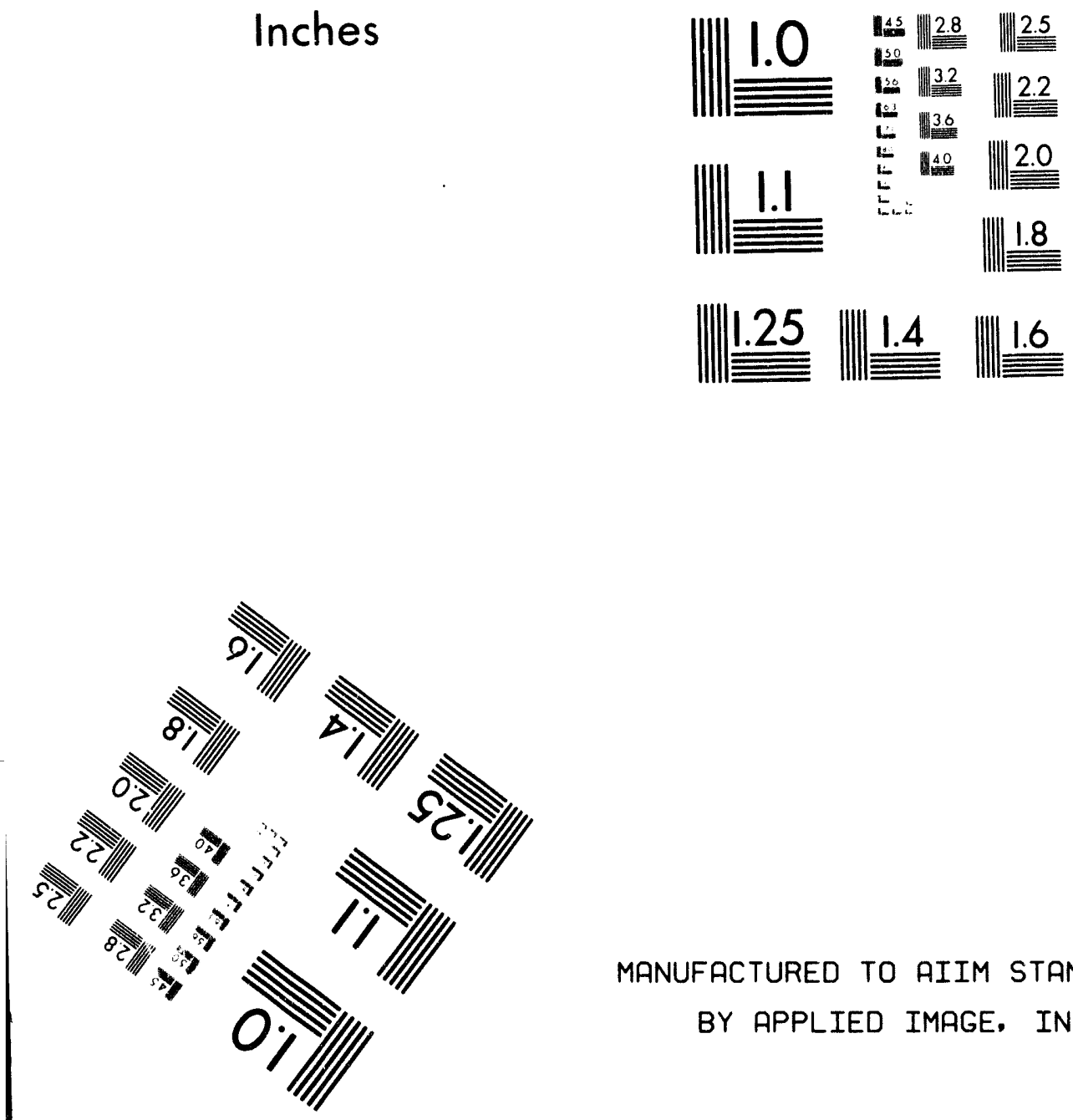

MANUFACTURED TO AIIM STANDARDS

BY APPLIED IMAGE, INC.

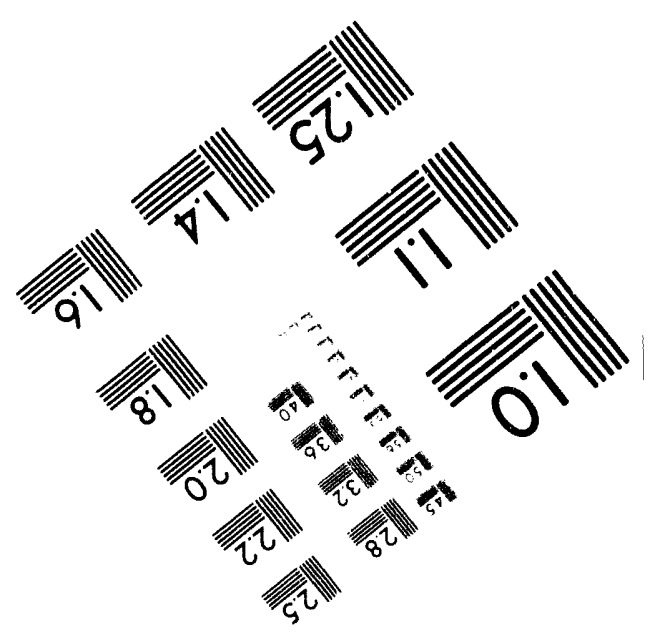



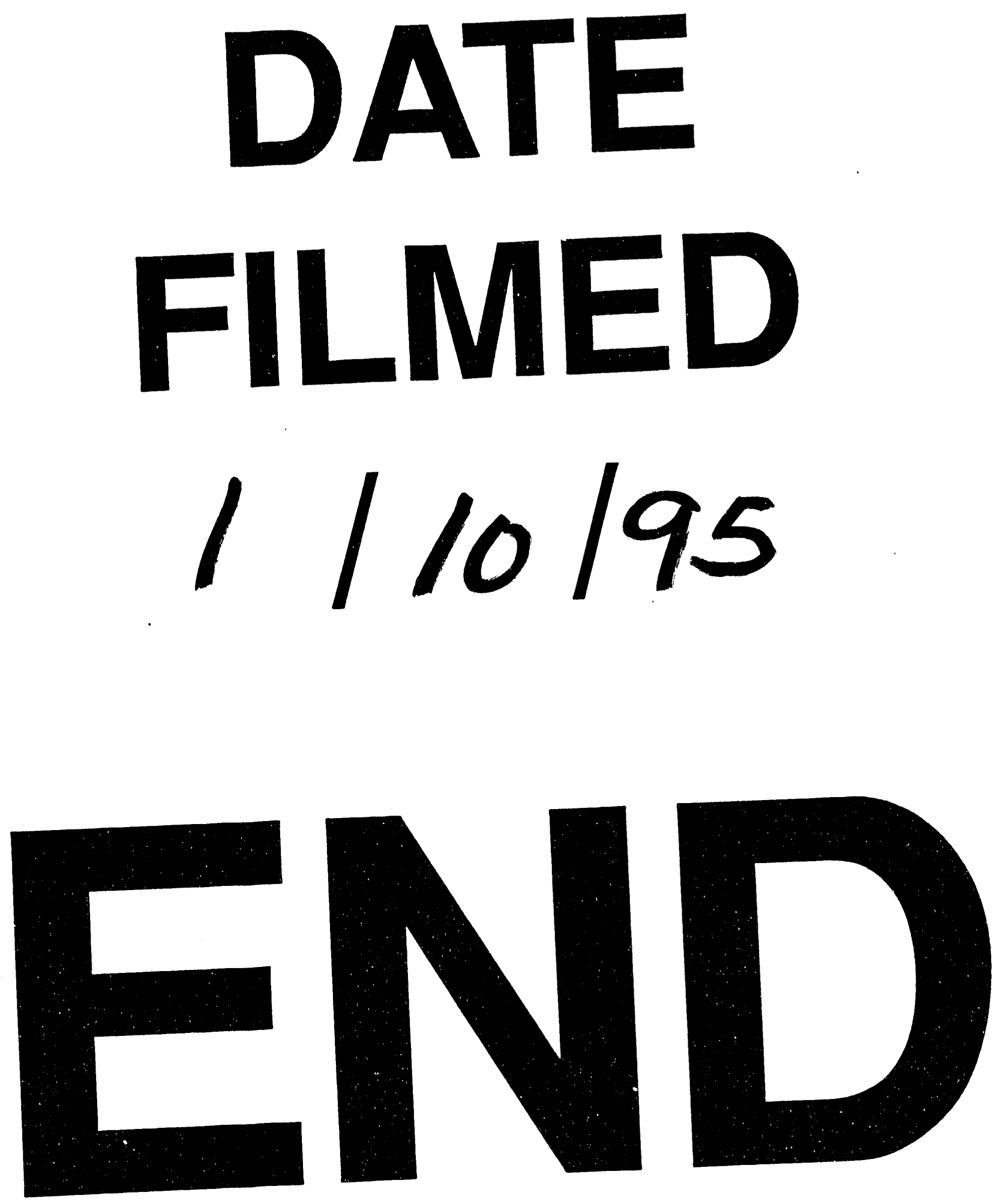